\title{
Marine Molluscs as Indicators of Environmental Change in Glaciated North America and Greenland During the Last 18000 Years
}

\section{Les mollusques marins et les changements du milieu dans la partie englacée de l'Amérique du Nord et du Groenland depuis 18000 ans \\ Meeresweichtiere als Indikatoren für Umweltveränderungen im vereisten Nordamerika und in Gröniand während der letzten 18000 Jahre}

\author{
Arthur S. Dyke, Janis E. Dale et Roger N. McNeely
}

Volume 50, numéro 2, 1996

URI : https://id.erudit.org/iderudit/033087ar

DOI : https://doi.org/10.7202/033087ar

Aller au sommaire du numéro

Éditeur(s)

Les Presses de l'Université de Montréal

ISSN

0705-7199 (imprimé)

1492-143X (numérique)

Découvrir la revue

Citer cet article

Dyke, A. S., Dale, J. E. \& McNeely, R. N. (1996). Marine Molluscs as Indicators of Environmental Change in Glaciated North America and Greenland During the Last 18000 Years. Géographie physique et Quaternaire, 50(2), 125-184. https://doi.org/10.7202/033087ar

\section{Résumé de l'article}

Les mollusques datés provenant de plus de 3000 collections ont été classés en paléo-zones fauniques. Hiatella arctica et Mya truncata comptent pour près de la moitié des relevés et comprennent un assemblage restreint à l'Arctique. Les assemblages arctiques ou à dominance arctique comptent respectivement pour $70 \%$ et $80 \%$ de l'ensemble des données. Sur les 170 taxons relevés, 15 espèces dominent. Au dernier pléniglaciaire, la zone arctique s'étendait de l'océan Arctique au Grand Banc. La zone boréale de l'Atlantique Ouest était comprimée. La zone subarctique, qui prédomine actuellement dans l'est du Canada, était peu étendue. La zone boréale occupait une grande superficie dans le Pacifique oriental alors que les zones arctique et subarctique étaient resserrées. Les zones se sont déplacées vers le nord au cours de la déglaciation et la zone arctique s'est diversifiée lorsque le détroit de Bering a été submergé de 10,5 à 10,3 ka BP. Les mollusques de l'Arctique occidental au cours du Dryas récent indiquent que les eaux peu profondes étaient plus chaudes que maintenant. Les principaux courants de l'Atlantique Nord se sont établis de 9,5 à 9,0 ka BP. La zone subarctique s'est étendue jusqu'à la tête (amont) de la mer de Baffin et une zone boréale s'est établie dans la partie ouest du Groenland vers 9-8 ka BP, avec des changements intenses vers 8,5 ka BP. La zone subarctique étendue s'est maintenue jusqu'à 3 ka BP, puis a reculé jusqu'à 1000 $\mathrm{km}$ du côté canadien. Les mollusques du Boréal-Subarctique présents dans le golfe du Saint-Laurent avant 9,5 ka BP provenaient du refuge glaciaire. Les mollusques du haut boréal-subarctique plus au nord provenaient probablement de l'Europe. Le courant du Labrador a sans doute agi comme pompe pour la migration des mollusques aux échelles glaciaire-interglaciaire. 


\section{MARINE MOLLUSCS AS INDICATORS OF ENVIRONMENTAL CHANGE IN GLACIATED NORTH AMERICA AND GREENLAND DURING THE LAST 18000 YEARS $^{*}$}

Arthur S. DYKE ${ }^{\star}$, Janis E. DALE, and Roger N. MCNEELY, respectively Terrain Sciences Division, Geological Survey of Canada, 601 Booth St, Ottawa, Ontario K1A 0E8; Department of Geography, University of Regina, Regina, Saskatchewan S4S OA2; Radiocarbon Dating Laboratory, Terrain Sciences Division, Geological Survey of Canada, 601 Booth St, Ottawa, Ontario K1A OEB.

ABSTRACT Dated mollusc collections are classified in assemblages to map paleofaunistic zones. Hiatella arctica and Mya truncata account for almost half the records and comprise a restricted arctic assemblage. Arctic assemblages comprise $70 \%$ and arcticdominated assemblages $80 \%$ of the database. Fitteen species dominate but 170 taxa are recorded. At last glacial maximum, the arctic zone extended from the Arctic Ocean to the Grand Banks. The boreal zone in the western Atlantic was compressed. The subarctic zone, which today dominates eastern Canada, was small. The boreal zone was extensive in the eastern Pacific where subarctic and arctic zones were compressed. Zones shifted northward during deglaciation and the arctic zone diversitied when Bering Strait submerged 10.5-10.3 ka BP. Western Arctic molluscs during Younger Dryas time indicate shallow waters warmer than present. Major North Attantic currents were established 9.5-9.0 ka BP. The subarctic zone extended to the head of Baffin Bay and a boreal zone became established in West Greenland $9.8 \mathrm{ka} \mathrm{BP}$, with intensive changes about $8.5 \mathrm{ka} \mathrm{BP}$. We relate the latter to the reduction of Mackenzie River discharge and in sea ice export to the North Atlantic as Laurentide ice withdrew from Mackenzie headwaters. The extended subarctic zone in Baffin Bay persisted until $3 \mathrm{ka} B \mathrm{~B}$ and then retreated about $1000 \mathrm{~km}$ on the Canadian side. Borealsubarctic moiluscs in the Gulf of St. Lawrence before $9.5 \mathrm{ka}$ BP derived from the glacial refugium. High boreal-subarctic mollusos far. ther north probably migrated from Europe. We postulate that the Labrador Current acts as a one-way valve for mollusc migrations at glacial-interglacial scales.
RÉSUME Les mollusques marins et les changements du milieu dans la partie englacée de l'Amérique du Nord et du Groenland depuis 18000 ans. Les mollusques datés provenant de plus de 3000 collections ont été classés en paléo-zones tauniques. Hiatella arctica et Mya truncata comptent pour près de la moitié des relevés et comprennent un assemblage restreint a l'Arctique. Les assemblages arctiques ou à dominance arcique comptent respectivement pour $70 \%$ et $80 \%$ de l'ensemble des données. Sur lés 170 taxons relevés, 15 espèces dominent. Au dernier pléniglaciaire, la zone arctique s'étendait de l'océan Arctique au Grand Banc. La zone boréale de l'Atlantique Ouest était compnimée. La zone subarctique, qui prédomine actuellement dans l'est du Canada, étaił peu étendue. La zone boréale occupait une grande superficie dans le Pacifique oriental alors que les zones arctique ot subarctique étaient resserrées. Les zones se sont déplacées vers le nord au cours de la déglaciation et la zone arctique s'est diversifiée lorsque le détroit de Bering a été submergé de 10,5 à 10,3 ka BP. Lés mollusques de l'Arctique occidental au cours du Dryas récent indiquent que les eaux peu profondes étaient plus chaudes que maintenant. Les principaux courants de l'Atlantique Nord se sont établis de 9.5 à 9,0 ka BP. La zone subarctique s'est étendue jusqu'à la tête (amont) de la mer de Baftin et une zone boréale s'est établie dans la partie ouest du Groenland vers 9-8 ka BP, avec des changements intenses vers $8,5 \mathrm{ka} B P$. La zone subarctique étendue s'est maintenue jusqu'à $3 \mathrm{ka} \mathrm{BP}$, puis a reculé jusqu'à $1000 \mathrm{~km}$ du côté canadien. Les moliusques ơu BoréalSubarctique présents dans le golfe du SaintLaurent avant $9,5 \mathrm{ka} \mathrm{BP}$ provenaient du re. fuge glaciaire. Les mollusques du haut boréal-subarctique plus au nord provenaient probablement de l'Europe. Le courant du Labrador a sans doute agi comme pornpe pour la migration des mollusques aux échelles glaciaire-interglaciaire.
ZUSAMMENFASSUNG Meeresweichtiere als indikatoren für Umweltveränderungen im vereisten Nordamerika und in Grönland während der letzten 18000 Jahre. Datierte Weichtier-Sammlungen wurden in Eirheiten klassifizient, um eine Karte der Paläo-FaunaZonen zu erstellen. Hiatella arctica und Mya truncata stellen fast die hältte der Aufstellungen und bestehen aus einer auf die Arktis beschränkten Einheit. Arktische Einheiten umfassen $70 \%$ und vorwiegend arktische Einheiten $80 \%$ der Datenbank. Fünizehn Spezies überwiegen, aber 170 Taxa sind belegt. Beim letzten glazialen Maximum erstreckte sich die arktische Zone vom Arktischen Ozean bis zu den Grossen Bänken. Die Boreal-Zone im West-Atlantik war komprimiert. Die subarktische Zone, welche heute Ostkanada beherrscht, war klein. Die Boreal-Zone war im Ostpazifik sehr ausgedehnt, während die subarktische und die arktische Zone komprimiert waren. Die Zonen verlagerten sich nordwärts während der Enteisung, und die arktische Zone wurde abwechslungsreicher, als die BeringMeerenge $10.5-10.3$ ka v.u.Z. auftauchte. Die hauptsächlichen Nordatlantikströmungen wurden $9.5-9.0 \mathrm{ka}$ v.u.Z. festgelegt. Die subarktische Zone erstreckte sich bis zum Kopt der Baffin Bay, und eine Boreal-Zone etablierte sich 9 - 8 ka v.u.Z. in WestGröniand, mit intensiveren Veränderungen etwa um $8.5 \mathrm{ka}$ v.u.Z. Die ausgedehnte subarktische Zone in der Baftin Bay erhiest sich bis 3 ka v.u.Z. und wich dann etwa 1000 $\mathrm{km}$ auf der kanadischen Seite zurück. Borealsubarktische Weichtiere im Golf des SanktLorenz vor 9.5 ka v.u.Z. stammten aus dem glazialen Refugium. Die Weichtiere aus dem subarktischen Hochboreal weiter im Norden kamen wahrscheintilch aus Europa. Wir behaupten, dass die Labrador-Strömung auf die Weichtier-Wanderungen im glazialeninterglazialen Massstab wie eine Klappe in einer Richtung wirkt.

Manuscrit reçu le 4 décembre 1995 ; manuscrit révisé accepté le 18 mars 1996

* Climate Systern History and Dynamics Project contribution 6-2;

Geological Survey of Canada contribution 35395

*"e-mail address : ad@gsc.NRCan.gc.ca 
"Little is known of the fate of boreal species, and to a lesser extent arctic-boreal species in the northwest Atlantic during the last glacial maximum... Post-glacial species movements remain largely unknown..." (Franz and Merrill, 1980, p. 236-237).

\section{INTRODUCTION}

Mollusc shells, particularly pelecypod shelts, are by far the most common macrofossils in Late Wisconsinan and Holocene raised marine deposits and more than 3000 collections from glaciated North America and Greenland have been radiocarbon dated at several laboratories. Although this is a large continental-scale paleoenvironmental data set, scant attention has been paid to changes in Late Quaternary mollusc assemblages through time. The taxonomic database has grown more through happenstance than through crafted research because collectors have most often submitted shells for dating in order to determine deglaciation and sea level histories rather than for paleoenvironmental research.

In this paper we examine changes in marine mollusc assemblages in glaciated North America (north of $40^{\circ} \mathrm{N}$ latitude) and Greenland from the last glacial maximum to today. We interpret nearshore marine conditions. Water mass temperatures and sea ice conditions modulate climate and broadly affect cyclogenesis and heat transfer to the atmosphere. Reconstructions of past conditions may be of use in validating paleoclimatic and paleoceanographic models and in evaluating feedbacks in the ocean-climate system. These are among the broad objectives of the Paleogeographic Atlas of Giaciated North America Project of the Geological Survey of Canada and the Climate Systems History and Dynamics Project. We use the radiocarbon time scale throughout. This departs increasingly from the calendar (sidereal) time scale back through time such that the last glacial maximum at 18000 radiocarbon years ago corresponds to about 22000 calendar years ago.

We summarize data below in three main sections: statistical summaries of species and assemblage percentages (see Fossil Mollusc Assemblages), "Regional Time Series of Mollusc Assemblages" for zoologically meaningful regions. and paleogeographic reconstructions of molluscan zones at 1000 year (1 ka) intervals (see Paleogeography). We then use the database to address the issue of species survival in the northwest Atlantic refugium alluded to in our opening quote (Franz and Merrill, 1980), followed by an examination of the record of Mya pseudoarenaria, which has experienced severe range retraction during the postglacial. Statistics and graphics are generated from computer databases that will be maintained and are available on request. Before these main sections we sketch the geological origins of mollusc groups of concern to this study and outline elements of oceanography and zoogeography that are necessary to interpret the fossil record. We also outline problems and biases inherent to the database that limit its utility but point to refinements. The term "mollusc" herein always refers to a marine mollusc.

\section{BACKGROUND TO MOLLUSCAN DISTRIBUTIONS}

All species of molluscs that occur in Late Pleistocene and Holocene deposits dealt with here are extant and many are of recent origin. Cold-water molluscs, common around nothern North America today, originated during the Late Cenozoic (Franz and Merrill, 1980; Lubinsky, 1980). Before about 3.2 million years ( $\mathrm{Ma}$ ) ago the Arctic Ocean was separated from the Pacific by an emergent Bering Strait, and its Tertiary molluscan launas were extensions of temperate Atlantic populations (Brouwers, 1994). A shallow Atlantic connection via Fram Strait was established 10-15 Ma ago (Lawver et al., 1990).

Cold-water molluscs can exchange between the Pacific and Atlantic only via the Arctic. Such exchanges started in Late Tertiary time. Early exchanges of cold-water forms involved many more species migrating from Pacific to Atlantic than vice versa, probably because of current-controlled pelagic larvae dispersion (Durham and MacNeil, 1967); both Pacific and Atlantic surface waters flow into the Arctic but Afctic surface water today exits only to the Atlantic (Herman, 1989). The major transarctic migrations occurred when the Arctic Ocean was relatively warm, during $1 \mathrm{Ma}$ or so between first submergence of Bering Strait and the onset of cyclic Northern Hemisphere glaciations about $2.4 \mathrm{Ma}$ ago (Late Pliocene; Shackleton et al., 1984). The first (or an early) opening of Bering Strait is recorded in lceland by appearance of several Pacific boreal molluscs. Shortly thereafter Pacificderived boreal species dominate the record (Einarsson et al., 1967; Eiriksson, 1980). In arctic Canada, this event is known only from Meighen Island, where Beaufort Formation marine beds contain a mixture of Pacific-derived and Atlantic-derived molluscs believed to represent the time immediately atter introduction of Pacific forms (Fyles et al., 1991). The Arctic Ocean - Greenland Sea may have been relatively warm (nearshore sea bottom temperatures $4-9^{\circ} \mathrm{C}$ ) during early (tirst?) glaciation(s) of northeast Greenland 2.4-2.6 Ma ago, as recorded in the Kap Kobenhavn and Lodin Elv formations (Penny, 1993), or they may have returned to warm conditions in the Late Pliocene (about 2 or $1.8 \mathrm{Ma}$ ago; Funder, 1989; Bennike and Böcher, 1990; Repenning and Brouwers, 1992) depending on the age assigned to these formations. The Kap Kobenhavn Formation contains the boreal mollusc Macoma balthica (Funder, 1989). Mudie et al. (1990) place the onset of glaciation around the shores of the Arctic Ocean, possibly alpine glaciation of Ellesmere Island, at $4 \mathrm{Ma}$ ago based on dropstone occurrences in cores from the submarine Alpha Ridge off the Canadian polar margin. Ice-rafted detritus first occurs in Late Miocene sediments in deep Baffin Bay (Cremer, 1989 ), but the pollen content of Baffin Bay sediment cores indicates persistence of boreal forests on Baffin Island and probably Greenland through the Pliocene and into the earliest Pleistocene (De Vernal and Mudie, 1989).

Mya arenaria, an important Pleistocene boreal mollusc, was the first Pacific form to reach the Atlantic via the Arctic. All but one species of $M y a$ ( $M$. producta) are of Pacific origin. Mya truncata, the second most common Late Quaternary molluscan fossil, occurred in the eastern North Atlantic by the 
Early Pleistocene. Late Wisconsinan $M$. truncata were the oldest known to MacNeil (1965) from the western North Allantic. However, we can now place it at the limit of radiocarbon dating, about $50 \mathrm{ka} \mathrm{BP}$, and likely to the Sangamonian in eastern Canada; it comprises $22 \%$ of dated shells in the range $30-50 \mathrm{ka} \mathrm{BP}$, all of which may be minimum ages. It occurs in the second lowest aminozone on eastern Baffin Island, which may be as young as 300 ka BP (Mode, 1985) or as old as Pliocene (Feyling-Hanssen, 1985). Macoma calcarea, one of the most common arctic-subarctic molluscs, migrated from Pacific to Atlantic as did Clinocardium ciliatum, Serripes groenlandicus and the boreal Macoma balthica, Mytilus edulis, and Neptunea despecta. Hiatella arctica, the most common Pleistocene moliusc in glaciated North America, and Astarte alaskensis ( $=A$. elliptica) were the first Atlantic forms to reach the Pacific (Late Miocene-Early Pliocene; MacNeil, 1965; Durham and MacNeil, 1967). The important fossil Chlamys islandica also is suspected to have migrated from Atlantic to Pacific (Franz and Merrill, 1980). The most common Quaternary marine invertebrates discussed in this paper are illustrated on Plates I and II, drawn mostly from the type collections of the Geological Survey of Canada.

Important aspects of present mollusc distributions are thought to have resulted from stresses of Quaternary temperature fiuctuations, from segregation of Pacific and Atlantic ranges during glaciations, and from extensions and retractions of ranges during and after deglaciation (Lubinsky, 1980). For example, many Pacific forms that made transarctic migrations during the Late Tertiary did not survive Pleistocene conditions in the North Atlantic; only 7 of 18 Pacitic species in the Early Pleistocene of Iceland survive today (Franz and Merril!, 1980, quoting Einarsson, 1964). Only more adaptive species have survived the oceanographic changes associated with the earlier Quaternary glaciations, which explains the lack of extinctions during the last glaciation. In this context, the apparent ongoing extinction of Mya pseudoarenaria, discussed below, is puzzling.

The present distribution of mollusc species along eastern North America is discontinuous. There is no smooth gradient from cold-water species to warm-water species between Labrador and southern New England. Bousfield and Thomas (1975) hypothesized that the disjunctions resulted from postglacial environmental changes: following a range extension, especially favourable niches in newly occupied territory continued to be occupied after general range retraction.

For the time and water depths considered here, two kinds of range extensions occurred: arctic and boreal species extended southward as ice sheets expanded, and subarctic, boreal, and temperate species extended noth of present limits during parts of postglacial time. Because temperate (Virginian) species ranged only marginally into the study area, this report primarily concerns arctic, subarctic, and boreal (coldtemperate) molluscs. We know from the stratigraphy of collection sites that most samples record shallow water conditions (<200 m; mostly <100 m).

\section{OCEANOGRAPHY AND COASTAL ENVIRONMENTS}

At a continental scale, shallow-water molfusc distributions are controlled by ocean surface water masses with contrasting temperatures, salinities, and sea-ice covers. Water mass distributions are dictated by the patterns and strengths of ocean surface currents (Fig. 1). Water masses at intermediate and greater depths have little or no effect on nearshore molluscs.

Arctic Surface Water ( 0 to $-2^{\circ} \mathrm{C} ; 28-32.5$ per mil salinity) carried by the Transpolar Drift continues southward through Fram Strait as the East Greenland Current. Other Arctic Surface Water, 30\% of total (Arctic System Science, 1990), filters through the Canadian Arctic Archipelago and continues southward along the east coast of Canada as the Baffin and Labrador currents $\left(-0.5\right.$ to $2.5^{\circ} \mathrm{C} ; 32-34$ per mil for Inner Labrador Current). These sweep subarctic conditions into middle latitudes and deflect the Gulf Stream eastward off Cape Hatteras, about $40^{\circ} \mathrm{N}$ (Piper et al., 1997).

Boreal (cool-temperate) Atlantic water is carried northward along the west coast of Greenland by the West Greenland Current $\left(4-6^{\circ} \mathrm{C}\right.$; 34-35 per mil) and subtropical (warmtemperate) Atlantic water is carried northward along the American and southeastern Canadian margins by the Gulf Stream and North Atlantic Drift. The Gulf Stream recurves southeastward off Nova Scotia but a branch continues northward as the North Atlantic Drift (35-36 per mil; $16-18^{\circ} \mathrm{C}$, decreasing to $3^{\circ} \mathrm{C}$ in Barents Sea). Warm offshoots move westward and mix with arctic waters, forming the Irminger $\left(6-10^{\circ} \mathrm{C}\right)$

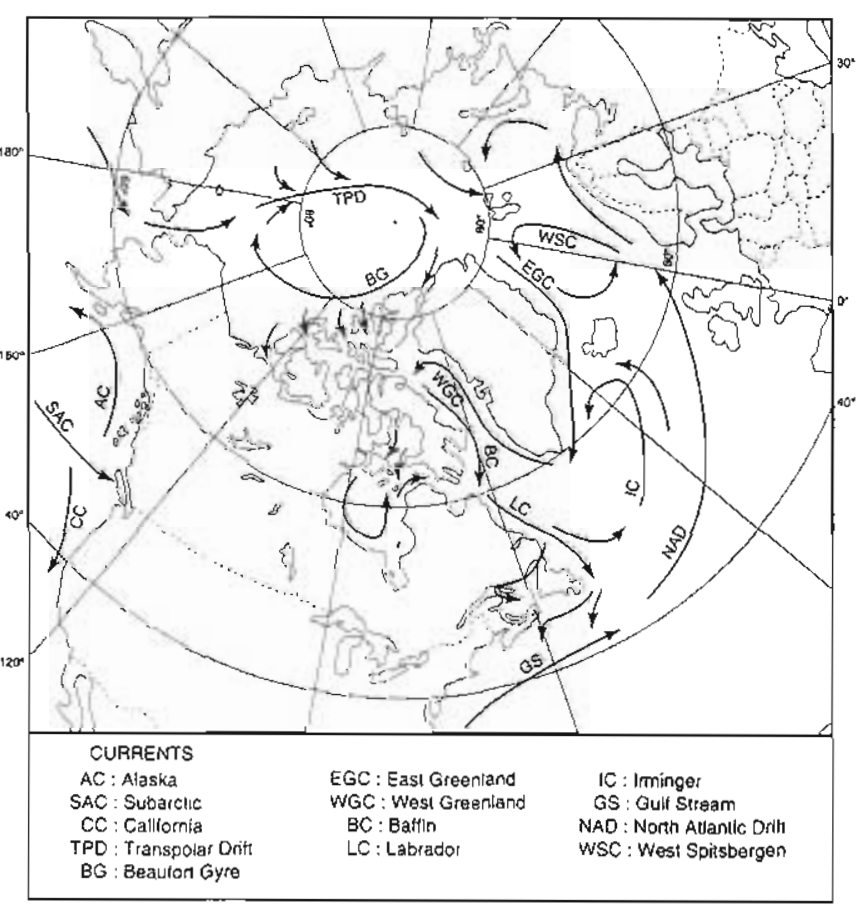

FIGURE 1. Ocean surface currents around northern North America and Eurasia.

Courants océaniques de surface autour du nord de l'Amérique du Nord ef de l'Eurasie. 


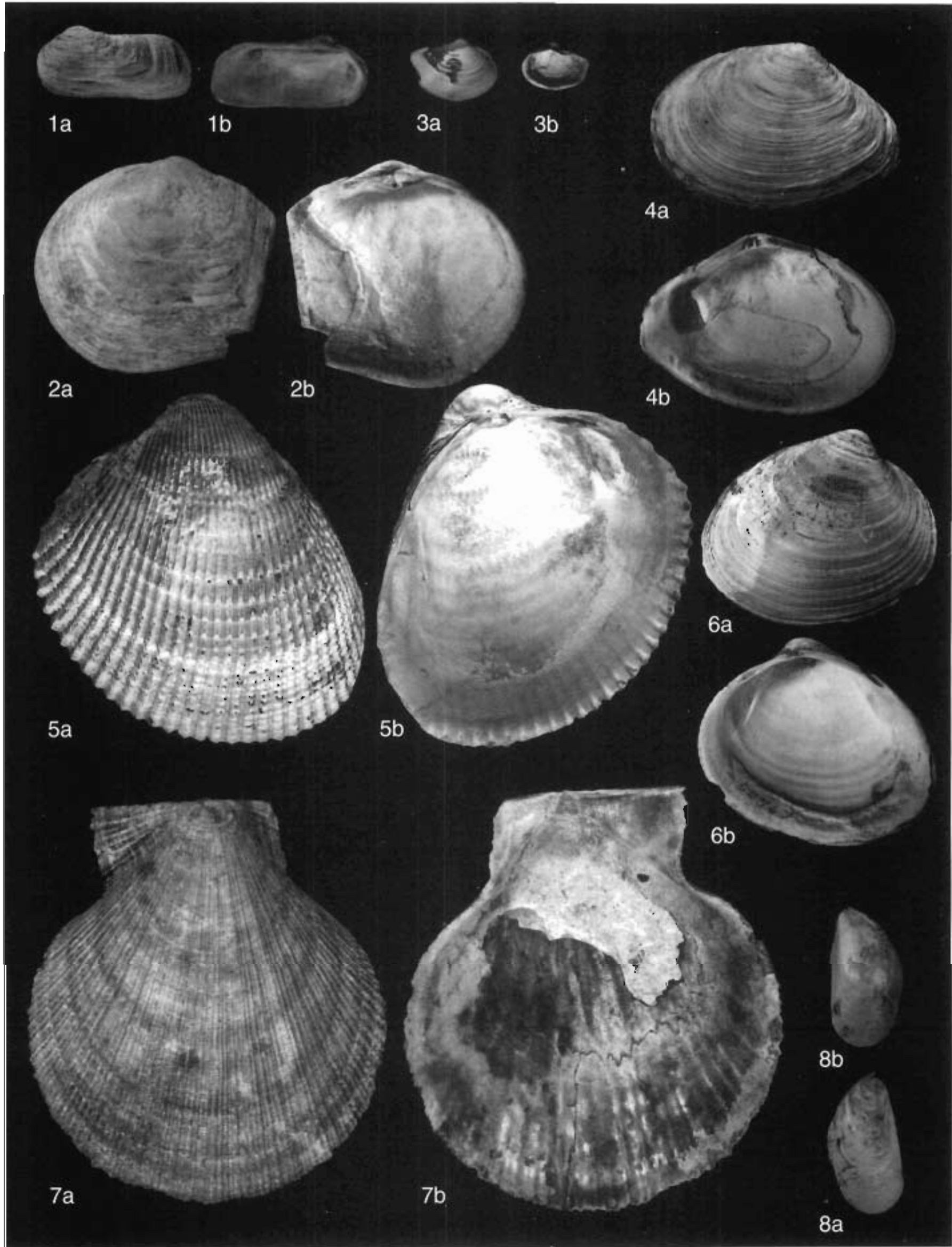


and West Spitsbergen currents. The former contributes the warm water to the West Greenland Current and the latter is responsible for the farthest northward extension today of boreal molluscs. A branch of the West Spitsbergen Current continues into the Arctic Ocean along the east side of Fram Strait. Its relatively warm $\left(>3^{\circ} \mathrm{C}\right.$ on entry) and saline (slightly above 35 per mil) waters then submerge to run below depths of $200-400 \mathrm{~m}$ (Coachman and Barnes, 1963). Most of this Atlantic Water re-exits the Arctic Ocean as an underlayer of the East Greenland Current after circulating counter-clockwise in the Arctic Ocean, below the opposing flow of the Beaufort Gyre. This two-way water flow through Fram Strait ac complishes $90 \%$ of the heat exchange between the Arctic Ocean and southern water masses (Kristoffersen, 1990). Shallow sills today prevent deep Atlantic water in the Arctic Ocean from traversing the Canadian Arctic Archipelago.

In the Pacific, the east-flowing, Subarctic Current strikes the coast at the latitude of Vancouver Island and splits to set up two opposing coastal currents: the Alaska Current carries warm water northward along the entire coast to the western Aleutian Islands while the California Current carries relatively cool (boreal) water southward nearly to the equator. This current pattern creates a much wider boreal zone in the eastern Pacific than its counterpart in the western Atlantic. Surface water from the North Pacific enters the Arctic Ocean via Bering Strait where it sweeps westward along the Siberian coast into the Beaufort Gyre and ultimately into the Transpolar Drift. Inflowing Pacific waters contribute much to the upper layers of the Arctic Ocean west of the submarine Lomonosov Ridge (10 times the annual inflow from all large Siberian rivers; Barry,

PLATE I. Ail shells are shown at actual size. 1) Hiatella arctica Linné. 1a, exterior; 1b, interior; GSC hypotype 20164; GSC negatives $113092 \mathrm{~K}, \mathrm{~L}$. 2) Mya truncata uddevallensis Forbes. 2a, exterior; 2b, interior; GSC hypotype 20162; GSC negatives 113096D, E. 3) Portlandia arctica Gray. 3a, exterior; 3b. interior; GSC hypotypes 20148, 20147; GSC negatives $113092 \mathrm{M}$, N. 4) Macoma calcarea Gmelin. 4a, exterior; 4b, interior; GSC hypotype 20158; GSC negatives $113092 \mathrm{M}$, N. 5) Clinocardium ciliatum Fabricius. 5a, exterior; 5b, interior: sample 69-1 (GSC-1337), L.A. Dredge; GSC negatives 1966-066B, C. 6) Serripes groenlandicus Bruguiere. 6a, exterior; $6 b_{r}$ interior; GSC hypotype 20156; GSC negatives 103094F, H. 7) Chlamys islandica Mülier. 7a, exterior; $7 \mathrm{~b}$, interior; sample 69-1 (GSC1337). L.A. Dredge; GSC negatives 1966-066E, D. 8) Mytilus edulis Linné. 8a, exterior; 8b, interior; GSC hypotype 20149; GSC negatives $113096 \mathrm{~F}, \mathrm{G}$.

PLANCHE 1. Tous les coquillages sonf illustrés grandeur nature. 1) Hiatella arctica Linné. 1a, extêrieur; 1b, intérieur; hypotype de la CGC 20164 : négatis de la CGC $113092 K$. L. 2) Mya truncata uddevallensis Forbes. $2 a$, extérieur; $2 b$, intérieur; hypotype de la CGC 20162 ; négatifs de la CGC 113096D. E. 3) Portlandia arctica Gray. 3a, extérieur ; 3b, intérieur; hypotypes de la CGC 20148 , 20147 ; négatifs de la CGC 113092M, N. 4) Macoma calcarea Gmelin. $4 a$, extérieur: $4 b$, intérieur; hypolype de la CGC 20158 ; négatits de Ia CGC 113092M, N. 5) Clinocardium ciliatum Fabricius. 5a, exterieur; 5b, intérieur; échantillon 69-1 (GSC-1337). L.A. Dredge ; négatifs de la CGC 1966-0668, C. 6) Serripes groenlandicus Bruguière. $6 a$, extérieur; $6 b$, intérieur ; hypotype de la CGC 20156 ; négatifs de la CGC 103094F. H. 7) Chlamys islandica Müller. 7a, extérieur; 7b. interieur; échantillon 69-1 (GSC-1337), L.A. Dredge; négatifs de la CGC 1966-066E, D. B) Mytilus edulis Linné. 8a, extérieur: 86 , intérieur; hypotype de la CGC 20149 ; négatifs de la CGC $113096 F, G$.
1989). Pacific water intruding the Beaufort Gyre forms a layer characterized by a shallow temperature maximum (50-100 m depth) above water of Atlantic origin and below Arctic Ocean Surface Water (Coachman and Barnes, 1961). A change in rate of Pacific inflow could affect the thickness of the Arctic Ocean surface layer.

\section{MOLLUSCAN ZOOGEOGRAPHY}

\section{MOLLUSCAN ZONES}

Marine molluscan zones are commonly, and herein, referenced to thermal conditions. Thus we refer to warmtemperate (Virginian; Californian), cold-temperate or boreal (Acadian, Oregonian), subarctic, and arctic zones, and to high and low arctic subzones. These zones have been defined for Greenland and North America (e.g. Madsen, 1936; Lubinsky, 1980; Bernard et al., 1991). Franz and Merrill (1980) discussed the origins and determinants of the distribution of arctic-boreal, boreal, and temperate molluscs along the eastern seaboard of North America. They too found that an important influence on mollusc distribution was their thermal requirements. But they emphasized that species groups "... are not merely correlates of the existing marine environment, nor the products only of thermal/geographic barriers. Rather these groups have clearcut Tertiary origins and ...their present distribution patterns are the result of environmental conditions in the Pleistocene, and especially the Holocene". That is, evolutionary history is probably as important as the conditions of the present environment in determining faunal distributions.

Major changes in species composition occur around Cape Hatteras and Cape Cod. Warm Transhatteran species decline sharply north of Cape Cod, as do cold arctic-boreal species south of there. The boreal group displays maximum success where the other two decline. The boreal species are largely endemic to the western North Allantic (65\%), having evolved there after formation of the Labrador Current System in the Tertiary (Franz and Merrill, 1980). This current separated European from American warm-water shelf areas, whereas earlier the Gulf Stream and its offshoots had warmed the Labrador Sea. Berggren and Hollister (1977) correlated the onset of the Labrador Current with the onset of Northern Hemisphere glaciation in the Late Tertiary at $2.4 \mathrm{Ma}$ ago. However, the Labrador Current operates under interglacial conditions today. In as much as it derives its cold water from the Arctic Ocean via the arctic archipelago and Fram Strait, its onset may correlate with formation of the arctic inter-island channels during the Middle to Late Tertiary rather than with glaciation (Kerr, 1980; Mudie et al, 1990; Dyke et al., 1992). Bohrman et al. (1990) suggested the onset of cold surface currents at $4 \mathrm{Ma}$ ago in the Labrador Sea (East Greenland Current) based on the beginning of biogenic opal accumulation. Gradstein and Srivastava (1980) placed the establishment of a Labrador Current in the Late Miocene to Middle Pliocene (5-3 Ma ago), as Arctic Ocean outflows tormed, but also suggested that the Labrador Shelf was not "fully swept" by cold southward currents until the Pleistocene.

The Transhatteran species are derived largely from American Miocene species that predate the transarctic migrations 


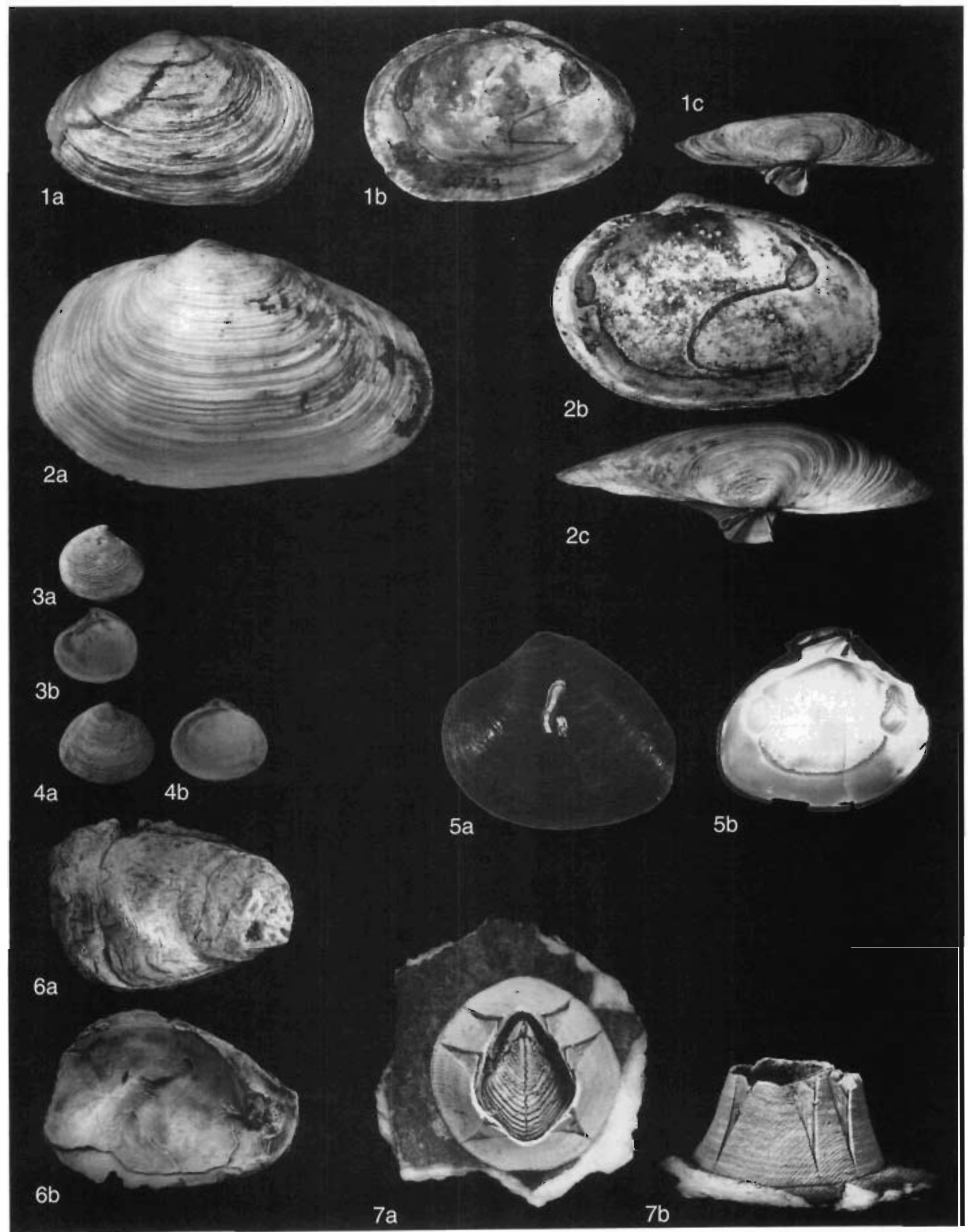


of cold-water forms. In contrast, $82 \%$ of the arctic-boreal faunas have an amphiatlantic/Pacific distribution and only $8 \%$ are endemic to the western North Atlantic. This group originated largely from transarctic migrations from the Pacific in the Late Tertiary.

While not negating the evolutionary overprint, thermal regime appears to play an important role in species diversity (Bernard et al., 1991). Species diversity declines with temperature in both Pacitic and Atlantic oceans. However, coldwater species have wider distributions because they inhabit lower latitudes by submerging to cooler waters at depth. Thus, there is a vertical zonation in non-arctic regions. Conversely, the small temperature difference between deep and shallow water in arctic seas results in relatively unrestricted depth ranges for some arctic molluscs there.

Minimum winter temperatures are not critical to molluscan distributions. Instead, Hall (1964) suggested that the number of consecutive days in summer when shallow water temperatures are warm enough for spawning and larval activity is critical. Bernard et al. (1991) found a strong positive correlation between mean annual surface temperatures and the number of intertidal bivalve species in the northeast Pacific. A weaker correlation was found for subtidal molluscs.

Our study area extends marginally into the warm-temperate zone in the Atlantic. In the Pacific, the boreal contacts the arctic zone along the Aleutian Islands and its southern boundary is at $34^{\circ} \mathrm{N}$. All Pacific fossil sites considered here lie in the present boreal zone; there are no dated molluscs from the arctic Bering Sea due to the lack of raised marine sediments.

PLATE II. All shells are shown at actual size. 1) Mya arenaria Linné. 1a, exterior ; 1b, interior : 1c, dorsal view ; GSC hypotype 20160; GSC negatives 113095J, $H, 1$. 2) Mya pseudoarenaria Schlesch. 2a, exterior; 2b. interior; 2C. dorsal view; GSC hypotypes 20163, 20163a; GSC negatives $113094 \mathrm{D}, 113097 \mathrm{~F}, 113094 \mathrm{E}$. 3) Astarte striata Leach. 3a, exteriof; 3b, interior; GSC hypotype 20151; GSC negatives 113092E, F. 4) Macoma balthica Linné. 4a, exterior; 4b, interior; GSC hypotype 20159; GSC negatives 113095C. D. 5) Astarte borealis Schumacher. 5a, exterior; $5 \mathrm{~b}$, interior; ${ }^{14} \mathrm{C}$ sample GSC-4853; GSC negatives 1966-066A, B. 6) Crassostrea virginica Gmelin. 6a, exterior; 6b. interior; GSC hypotype 20150; GSC negatives 113097C, D. 7$)$ Balanus hameri Ascanius. $7 a$, top view of adult individual attached to a scallop shell; $7 \mathrm{~b}$, side view; GSC hypotype 20193; GSC negatives $113234 \mathrm{l}, \mathrm{B}$

PLANCHE II. TOus les coquillages sont illustrés grandeur nature. 1) Mya arenaria Linné. 1a, exterieur; 16 , intérieur ; $1 \mathrm{c}$, vue dorsale; hypotype de la CGC 20160; négatifs de la CGC 113095J, H. I. 2) Mya pseudoarenaria Schlesch. 2a, exterieur: 2b, intérieur; $2 c$. vue dorsale; hypotypes de la CGC 20163, 20163a ; négatifs de la CGC 113094D, 113097F, 113094E. 3) Astarte striata Leach. 3a, exterieur; $3 b$, interieur; hypotype de la CGC 20151 ; négatifs de la CGC $113092 E, F$. 4) Macoma balthica Linné. 4a, exterieur; $4 b$, interieur; hypotype de la CGC 20159 ; négatifs de la CGC 113095C, D. 5) Astarte borealis Schumacher. $5 a$, extérieur; 5 b, intérieur : échantilon GSC-4853; négatifs de la CGC 1966.066A, B. 6) Crassostrea virginica Gmelin. 6a, extérieur; $6 b$, intérieur; hypotype de la CGC 20150 ; négatifs de la CGC $113097 C, D$. 7) Bakanus hameri Ascanius. $7 a$, vue verficale d"un individu adulte attaché à un coquillage; $7 \mathrm{~b}$, vue de cóté; hypotype de la CGC 20193; negalits de la CGC $113234,8$.

\section{ARCTIC MOLLUSCS}

After Late Cenozoic cooling created a thermal barrier to transarctic migrations, waters from the Atlantic Ocean played the prominent role in the distribution of arctic species. Most arctic taxa have affinities with Atlantic boreal species (Fedyakov and Naumov, 1989; Golikov, 1989). Influence of Pacific waters has been less significant. Only Pacific species that can move through the cold waters of Bering Strait can spread into the Canadian Arctic and Greenland. Macoma inconspicua is one of few Pacific endemics found in the southwestern Canadian Arctic Archipelago. Of 101 species of molluscs identified by Wagner from the Canadian Beaufort Sea, $33 \%$ are known from both Atlantic and Pacific oceans; $51 \%$ are recorded from the Atlantic but not the Pacific, and only $6 \%$ are reported from the Pacific but not the Atlantic (Vilks et al., 1979). Although the $6 \%$ shared with the Pacific distinguishes the Beaufort region from the rest of the Canadian Arctic, Atlantic affinity dominates the present fauna even there. However, data presented below show that the last opening of Bering Strait had an important impact on postglacial evo. lution of Canadian arctic faunas.

Interest has increased recently in the marine biology, sedimentology, and oceanography of cold regions of Canada, but many important concepts were established by Danish researchers in Greenland. Madsen $(1936,1940)$ first divided Greenland waters into arctic and subarctic (or boreo-arctic) zoogeographical zones. The boundary is marked by the northern limits of certain littoral animals, such as Littorina saxatilis, Mytilus edulis, and Balanus balanoides. This boundary was placed $1100 \mathrm{~km}$ farther north on the west coast of Greenland $\left(73^{\circ} 05^{\prime} \mathrm{N}\right)$ than on the east $\left(66^{\circ} 67^{\prime} \mathrm{N}\right)$. Madsen (1936) correctly speculated that the farther penetration of warm fauna on the west coast was due to admixing of warm water from the Irminger Current with polar water in the West Greenland Current.

Dunbar (1946) recognized the significance of Madsen's zones to the distribution of fittoral and other northern faunas and to hydrographic conditions in the Canadian Arctic. The northern limit of boreal molluscs occurs along Cumberland Peninsula near Cape Dyer $\left(67^{\circ} \mathrm{N}\right)$ on the Canadian side of Baffin Bay, about $1000 \mathrm{~km}$ south of the limit on the Greenland side (Andrews et al., 1980). This dramatically illustrates the influence of the cold Baffin Current off eastern Canada. Madsen's observations have been confirmed by further research on Greenland shores (Bertelsen, 1937; Vibe, 1939). The Canadian limits were confirmed by Ellis $(1955,1960)$.

Investigation of arctic mollusc communities and environmental tolerances began with Thorson's $\{1933,1934)$ work in northeast Greenland. He defined several communities, the most extensive being the Macoma calcarea community in water depths of $3-45 \mathrm{~m}$. He also studied larval development and determined that temperatures $\angle 4^{\circ} \mathrm{C}$ exclude most boreal species; only fauna capable of reproduction at lower temperatures can inhabit arctic waters. About $70 \%$ of species studied spawned successfully at temperatures $\angle 2.5^{\circ} \mathrm{C}$. About $95 \%$ of benthic invertebrates from northeast Greenland complete their larval development without a pelagic stage. Non-pelagic development is particular to all species found solely in the 
Arctic and to some deep-sea species, but to few cosmopolitan shallow-water forms. Those species with pelagic larval development present in the Arctic extend into lower latitudes. Pelagic stages are short ( $<1$ month), suggesting high metabolism. Thorson noted that some species that exhibit non-pelagic development in the North switch to pelagic modes in the South. For many benthic organisms, the planktonic larval stage is the main means of dispersal. However, Martel and Chia (1991) found that juveniles and small adults of Mytilus edulis, $M$. californianus, and Hiatella arctica can drift to new sites. This was an advantage to these species in extending their ranges during deglaciation.

Cold-water molluscs have a further advantage in postglacial dispersion because they tolerate wide ranges of marine conditions. They exploit short ice-free periods and tolerate long winters with negative water temperatures and seasonally varying salinities; some robust species such as Hiatella arctica and Mya truncata can survive the abrasive action of sea ice in the intertidal zone. Some have evolved reproductive strategies where large-yoked eggs or nurse eggs increase probability of success.

Thorson (1936) suggested that low temperatures were responsible for slow growth rates, great Jongevity, and late maturity (third summer or later) of arctic bivalves. Slow growth rates have been confirmed for Canadian arctic species, notably Mya truncata (Hewitt and Dale, 1984). Consequently one would expect to find a high proportion of juveniles in arctic environments. Ockelmann (1958) studied the bivalves of eastern Greenland. He identified characteristic bivalves that occur in East Greenland Current and fiord waters and noted Holocene range extensions. East Greenland Current waters with temperatures of $0^{\circ}$ to $-1.7^{\circ} \mathrm{C}$ hosted, among others, Portlandia arctica, P. (= Yoldiella) lenticula, P. (= Yoldiella) frigida, $P$. (= Yoldiella) fraterna, Lima hyperborea, and Pandora glacialis.

Recent studies of mollusc-sediment relationships may be useful in interpreting fossil records. Gulliksen et al. (1985) showed that a high suspended sediment content of water reduces phytoplankton production and thus faunal abundance. Görlich et al. (1987) noted reduced biomass of macrobenthos in Hornshund Fjord, Svalbard due to settling of suspended sediment from tidewater glaciers.

Canadian research is less comprehensive than work accomplished in Greenland. The most extensive early faunal collections were made during the second Norwegian Arctic Expedition (1898-1902) in Jones Sound (Grieg, 1909). The Canadian Arctic Expedition (1913-18; Verrill, 1922) and Fisherjes Research Board Calanus cruises (1948-61; Dunbar and Grainger, 1952) provided the first lists and descriptions of marine invertebrates from large areas. Ellis (1957) and Curtis (1975) list other early studies of Canadian arctic benthic fauna. These and other studies outlined the distributions of common molluscs (Bousfield, 1960; Macpherson, 1971; Bernard, 1979; 1983; Lubinsky, 1980; Smith, 1981; Wagner, 1984). More recent surveys include those of Clarke (1974) and Syvitski et al. (1989) in Baffin Bay, Wagner (1975) in Strait of Canso, and Vilks et al. (1979) on the Beaufort Shelf.
Quantitative studies of cold-water molluscs are few because of limited accessibility. This constrains understanding of modern molluscan ecology and zoogeography and limits our abjlity to draw generaljzations from the fossil record. Few quantitative studies have concentrated on intertidal and upper subtidal zones, and the works of Ellis (1955, 1960) and Ellis and Wilce (1961) still provide benchmarks for the Canadian Arctic, particularly for southern Baffin Island. They described a seaward-increasing density of fauna below the generally barren zone above mean tide level. Intertidal molluscs of southern Baffin Island have been further studied by McCann ef al. (1981), Aitken and Gilbert (1986, 1989), and Dale (1992). McCann et al. noted that gastropods are most common on inner intertidal flats and bivalves on the outer. In areas of emergence, the outer tidal flat environment, with its thicker sediments, has better preservation potential which would tend to bias the record in favour of bivalves. Mya truncata survives well on the outer flat where firm, cohesive sediment prevents burrows trom collapsing.

The typical arctic, shallow-water community is the Macoma community on sandy sites. This is dominated by Macoma calcarea with Mya truncata, Serripes groenlandicus, and Hiatella arctica. The large intertidal flats of Baffin Island contain pockets of Cyrtodaria kurriana, Thracia myopsis, and Astarte borealis. Portlandia arctica dominates deeper mud bottoms. In contrast, high arctic intertidal sites on eastern Ellesmere Island exhibit lower densities and diversities of organisms: Axinopsida orbiculata, Hiatella arctica, and Mya truncata occur in low densities along with gastropods such as Cylichna alba and Oenopota bicarinata (Dale, 1985).

Subtidal molluscs in Canadian arctic fiords have been studied recently. Syvitski et al. (1989) compared a number of Baffin Island fiords but local environmental effects are difficult to separate from possible latitudinal controls on differences in communities. Aitken and Fournier (1993) and Dale et al. (1989) examined the macrobenthos, including molluscs, in several east-central Baffin Island fiords. A Portlandia association there occupies prodelta environments, characterized by abundant $P$. arctica and other motile deposit feeders such as Axinopsida orbiculata and Nucula bellotti. Aitken and Gilbert (in press) described moltuscs along shallow to deepwater transects in Expedition Fiord $\left(79^{\circ} \mathrm{N}\right)$, Axel Heiberg Island, the most northerly such study site in Canada. They found 36 species of molluscs (including 8 gastropods and 17 bivalves) forming two associations. A Portlandia - Thyasira association, with two molluscs only, occupies the deep prodelta environment with summer temperatures $\angle 0^{\circ} \mathrm{C}$ and salinities <25 per mil. Away from the delta this association diversities to include Yoldiella spp. and Delectopecten greenlandicus. A Macoma - Astarte association, with 7 common high arctic species, occupies shallower water $(3-32 \mathrm{~m})$ away from the brackish river mouth and its areas of high suspended sediment. The upper $3 \mathrm{~m}$ are barren due to destruction of molluscs by sea ice.

\section{LATE WISCONSINAN AND HOLOCENE MOLLUSCS -PREVIOUS WORK}

Paleontological interest in postglacial molluscs seems to have been greatest before radiocarbon dating. Careful early 
inventories of fossils were made by Dawson (1893), Laursen (1950), and Richards (1962; reporting work mainly before 1950). Systematic inventories for several arctic regions by Wagner (1969 and in Craig, 1960, 1961, 1963, and unpublished) and her survey of Champlain Sea fossils (Wagner, 1970) had limited radiocarbon support. Similarly, the treatment of marine Pleistocene faunas of southwestern British Columbia by Wagner (1959) is not supported by radiocarbon dates, even though some were in hand (Armstrong, 1956; Fyles, 1963). Bousfield and Thomas (1975) interpreted the disjunct nature of shallow-water molkuscan and crustacean faunas between Labrador and southern New England in terms of possible postglacial migrations. They inferred a water temperature history that involved a Hypsithermal $2.5^{\circ} \mathrm{C}$ warmer than present, but the paleoenvironmental sequence that they presented was entirely hypothetical in that they did not utilize fossil mollusc data. Many more recent studies include lists of postglacial marine invertebrates and these have been incorporated in our database. Below we outline those that document dated ecostratigraphic zonations or range extensions.

Matthews (1967a) discussed postglacial changes in molluscan faunas in Frobisher Bay. He identified three species with age estimates of 6-6.5 ka BP that do not occur in Canadian arctic waters at present: Volsella demissa, Nucula delphinodonta, and Lyonsia hyalina. The first and last of these represent extreme range extensions in that they do not now occur north of the southwestern Gulf of St. Lawrence, and hence have a Virginian distribution. N. delphinodonta ranges north to Hudson Strait. Because they are not directly dated and their fragmented nature suggests the possibility of misidentification, they are not included in the present database. The surprising presence of Virginian taxa in this area has not been confirmed despite much additional work. Deposits estimated by Matthews to be older than $6.5 \mathrm{ka} \mathrm{BP}$ contain only Hiatella arctica and Mya truncata

Matthews (1967b) reported a rich cirriped and mollusc ( 31 pelecypods, 20 gastropods) assemblage from postglacial raised marine deposits of the Ungava shore of Hudson Strait. The dated faunas are included in the present database. He identified 8 species that represent range extensions, mostly of boreal-subarctic species now occurring along the Labrador coast but also including the temperate $L$. hyalina, during the period 5.2-3.9 ka BP. He pointed out that the apparent marine temperature optimum here was displaced in time from that in Frobisher Bay. Wagner (1969) documented 26 pelecypod and 27 gastropod species in Tyrrell Sea fossil collections. Those that have been dated are included here. She concluded that samples collected at altitudes $>122 \mathrm{~m}$ indicated more brackish conditions than present but similar water temperatures $\left(\angle 0^{\circ} \mathrm{C}\right)$. These samples contained only Hiatella arctica, Mya truncata, Clinocardium ciliatum, and Macoma balthica. The last of these is a boreal-subarctic species but the first two are much more common. Specimens collected at altitudes $<61 \mathrm{~m}$ indicated modern low arctic marine conditions, with salinities $\leqslant 33$ per mil. Wagner interpreted this zonation as reflecting deglaciation - decreasing meltwater influx and land uplift.
Andrews (1972) documented growth rates and range extensions of Holocene molluscs on Baffin Island. The southem species Mytilus edulis, Chlamys islandica, and Macoma balthica extended their ranges in the middle Holocene 18.2 $2.8 \mathrm{ka} \mathrm{BP}$ ) and retreated during the Neoglacial. The database for this region has since been expanded and care has been taken to document range extensions. Hjort and Funder (1974) dated subfossil occurrences of Mytilus edulis in central East Greenland to 8-5.5 ka BP. They suggested that it migrated from Svalbard via the West Spitsbergen Current, rather than advancing from southern Greenland where it occurs today.

Funder and Weidick (1991) documented range extensions of boreal molluscs in West Greenland between 8.4 and $4.9 \mathrm{ka}$ BP. These include 6 species now regionally extinct: the gastropod Emarginula fissura and the bivalves Heteranomia squamula, Modiolus modiolus. Arctica islandica, Panopea norvegica, and Zirphaea crispata. The first two are not directly dated and hence not included in our database. They estimated that water temperatures rose $1-3^{\circ} \mathrm{C}$ above present. Temperatures there are controlled by the mix of polar versus Atlantic waters in the West Greenland Current.

Champlain Sea molluscs are the best studied in Canada, with a history of investigation that dates back 101837 (Baytield, 1837; Lyell, 1841; Wagner, 1970; Elson, 1969a, b; Hillaire-Marcel, 1980; Rodrigues, 1987; Rodrigues and Richard, 1983, 1985, 1986). Wagner (1970) analyzed extensive collections and concluded that the Champlain Sea did not attain normal salinities even in its central basin. Relatively high salinities of $>20$ per mil were associated with deep water areas where Portlandia arctica lived. She considered that the mollusc assemblages represented boreal conditions. But she also reported five species that appear to represent early range extensions of temperate faunas into the eastern Champlain Sea. These species now range north only to southwestern Gulf of St. Lawrence and their first appearance in the region may well be represented by the still undated collections of Wagner. Neptunea despecta tornata is recorded at five localities, Crassostrea virginica and Yoldia limatula at two. Mysella planulata and Lyonsia hyalina each at one. Ardley (1912) had earlier reported a collection of oyster fossils from a depth of $3 \mathrm{~m}$ below the surface at Montreal. Oysters require water temperatures of at least $20^{\circ} \mathrm{C}$ for viability.

Rodrigues and Richard (1986) reviewed earlier work on the Champlain Sea. Elson's (1969a, b) suggestion of a twofold biostratigraphy - a cold, deep-water, Hiatella arctica phase succeeded by a warmer, shallow-water, Mya arenaria phase - has proven too simple. Rodrigues and Richard recognized 5 ecostratigraphic pelecypod and cirriped associations and showed that the Hiatella association persisted to near the end of the sea. Salinity and substrate exerted the major controls over these associations, with the barnacle Balanus hameri indicating deep, high salinity (30-34 per mil) water. HillaireMarcel (1980) detailed changes of species during deglaciation in the Tyrrell, Goldthwait, and Champlain seas. He recognized 6 pelecypod communities of the Champlain Sea that shifted with changing water depths and other conditions following deglaciation. 


\section{PROBLEMS AND BIASES}

\section{PRESERVATION}

The faunal assemblage at a fossil site is only the record of species that were preserved and the complete faunal cormmunity can not be reconstructed. Soft-bodied species have been lost. In addition, many smaller shells may not have survived burial or may be overlooked during collection.

Burial rates, transport history, sediment chemistry (acidity), and ground temperature (permatrost) all partly determine preservation potential of shelled taxa. These control rates of abrasion, fragmentation, dissolution, and staining of shells (Powell and Davis, 1990). For example, Valentine (1989) compared mofluscs inhabiting the California shelf with species collected in onshore Pleistocene deposits. He found that $77 \%$ of living species were preserved in the fossil record. Postburial destruction appeared responsible for most loss of species, not initial lack of shells. He also found that differences in preservation between gastropods (76\%) and bivalves (80\%) were due to a predominance of epifaunal species in the former and infaunal species in the latter. Aitken (1990) calculated that $66 \%$ of modern shelled macrobenthos of Baffin Island (mainly bivalves and gastropods) are represented in the local Quaternary fossil record but that $68-86 \%$ of all genera (mainly soft bodied) have no preservation potential; infaunal suspension feeders and epifaunal browsers are preferentially preserved.

Palmqvist (1991) suggested that differences in preservation between trophic groups are due to initial abundances; primary consumers like pelecypods are usually more abundant than higher trophic groups like carnivorous gastropods. Other differences in preservation may relate to variations in mobility, size, and skeletal nature. For example, many primary consumers are sessile and targe and grow thick shells to protect against predators; secondary consumers tend to be mobile and smaller and grow thinner shells.

For the raised marine deposits that hold the fossils of concern to this paper, the most important geological factors affecting preservation probably are presence or absence of permafrost, sediment acidity, and sediment permeability. Fossils are much more commonly found in areas of permafrost than farther south, particularly in acidic terrain. South of permafrost, fossils are better preserved in calcareous than in acidic sediments. In acidic terrain, they are generally restricted to fine-grained sediments of low permeability. It appears that carbonate shells are leached from coarser sediments over the course of a few thousand years

\section{COLLECTING, REPORTING, AND IDENTIFICATION}

Radiocarbon dating has been done mostly on monospecific groups of robust shells, with preference for well-preserved shells collected from growth positions. Although this reduces the risk of incorporating age mixtures in dated subsamples, it can introduce a bias in any taxonomic database based on radiocarbon dates. This bias is alleviated when the submitter reports other taxa in the collection or at the site. But this is not always done. An extreme sampling bias occurs when only one or a few large, easily recognized species, those most commonly used in radiocarbon dating, are collected or recorded. The extent of this bias can be assessed only by re-examination of hundreds of samples scattered in dozens of collections at various institutions. However, $17 \%$ of the radiocarbon dates have been published without identification of even the dated shells, which suggests that the bias may be substantial. On the other hand, many radiocarbon dates are published with comprehensive species lists. It would be exceedingly helpful to future research if collectors of radiocarbon samples ensured that all species are included in their samples and if full documentation of dated samples were deposited in the Canadian Radiocarbon database. Ideally, all samples should eventually reside in a national collections.

Identification of species is problematic for some entries in the database. Generally, samples identified only to genera are those that were too fragmented for specific assignment. Some problems arise from evolving nomenclature but can be impossible to correct without access to original samples. For example, the few Mya arenaria recorded from the Canadian Arctic are likely $M$. pseudoarenaria in that the former has never been identified in modern arctic collections (Lubinsky, 1980). Further inconsistencies of identification may have resulted from the many researchers, usually sample submitters, involved. We assume original identifications to be correct but have updated archaic nomenclature (Appendix). Few obvious cases of misidentification (e.g. a Pacific species reported from the Atlantic) are retained in the database but not used.

Mixing of Arctic and Atlantic waters results in mixing of arctic and boreal species. Arctic species tend to occupy deeper water with decreasing latitude and live below boreal communities. This creates a potential for conflicting interpretation of paleoenvironments. However, most shells in the database were collected above present sea level and at a known altitude below the postglacial marine limit. Many were dated because of their sedimentological affinity to former shorelines. Most represent communities that lived in water depths of a few metres to a few tens of metres. A small subset of samples from continental shelf sediment cores are generally of shells in growth position, and hence from known paleo-water depths.

\section{METHODS}

Radiocarbon dates on marine shells dating $<20 \mathrm{ka} B P$ were compiled from the literature, yielding a database of 3083 entries. Radiocarbon ages are corrected for the marine reservoir effect by subtracting 400 years whenever pertinent protocol information was available; otherwise dates are used as originally published. No taxa identifications were found (other than "marine shells") for 503 dated samples (16.6\% of database) and a further 115 samples (3.7\%) recorded only widespread taxa, many identified only to genera. Thus analysis herein relies on 2465 identified assemblages of known age and location (Table I). Every effort, including correspondence with submitters and reference to unpublished and limited-circulation data files (e.g. Robertson, 1987; Bigras and Dubois, 1987). was made to compile a full list of taxa in dated samples, rather than just the dated taxon. The database, which is in spreadsheet format and is current as of 1993 , is filed 
TABLE I

Abundances of dated mollusc and cirriped assemblages as percent of classified samples

\begin{tabular}{|c|c|c|}
\hline Assemblage & $\begin{array}{l}\text { No. of } \\
\text { samples }\end{array}$ & $\%$ \\
\hline 1. Hiatella arctica only & 540 & 21.9 \\
\hline 2. Mya truncafa only & 360 & 14.6 \\
\hline 3. H. arctica and $M$. truncata & 268 & 10.9 \\
\hline Restricted arctic $(1+2+3 ;$ RA $)$ & 1168 & 47.4 \\
\hline 4. Portiandia arctica & 91 & 3.7 \\
\hline Restricted arctic $(1+2+3+4 ;$ RA $)$ & 1259 & 51.1 \\
\hline 5. Mya pseudoarenaria $\pm 1,2,3,6$ & 33 & 1.3 \\
\hline 6. Other arctic species $\pm 1,2,3$ & 437 & 17.7 \\
\hline Diverse arctic $(5+6 ;$ DA) & 470 & 19.1 \\
\hline Arctlc only (subtotal) & 1729 & 70.1 \\
\hline 7. $H$. arctica +1 boreal species & 42 & 1.7 \\
\hline 8. M. truncata +1 boreal species & 11 & 0.4 \\
\hline 9. Both $(7 \& 8)+1$ boreal species & 30 & 1.2 \\
\hline 10. $P$. arctica +1 boreal species & 2 & 0.0 \\
\hline 11. $M$ pseudoarenaria +1 boreal species & 6 & 0.2 \\
\hline 12. Other arctic species +1 boreal species & 112 & 4.5 \\
\hline Arctic assemblages +1 boreal species & 203 & 8.2 \\
\hline 13. M. truncata +2 boreal species & 2 & 0.0 \\
\hline 14. H. arct. \& M. tr. +2 boreal species & 4 & 0.2 \\
\hline 15. $M$. pseudoarenaria +2 boreal species & 5 & 0.2 \\
\hline 16. Other arctic species +2 boreal species & 39 & 1.6 \\
\hline Arctic assemblages +2 boreal species & 50 & 2,0 \\
\hline 17. M. pseudoarenaria +3 boreal species & 3 & 0.1 \\
\hline 18. Other arctic species +3 boreal species & 10 & 0.4 \\
\hline Arctic assemblages +3 boreal species & 3 & 0.5 \\
\hline Arctic assembiages with boreal species (AB) & 266 & 10.8 \\
\hline Arctic dominated (subtotal) & 1995 & 81.9 \\
\hline 19. 2 boreal species $+H$. arctica & 8 & 0.3 \\
\hline 20. 2 boreal species $+M$. truncata & 2 & 0.0 \\
\hline 21. 2 boreal species + H.a. \& M.t. & 2 & 0.0 \\
\hline 22. 2 boreal species $+P$. arctica & 1 & 0.0 \\
\hline Restricted boreal assemblage with arctic species & 13 & 0.5 \\
\hline 23. 3 boreal species $+H$. arctica & 4 & 0.2 \\
\hline 24. 3 boreal species $+M$. truncala & 4 & 0.2 \\
\hline 25. 3 boreal species + H.a. \& M.t. & 2 & 0.0 \\
\hline 26. 3 boreal species + M. pseudoarenaria & 2 & 0.0 \\
\hline Boreal assemblages with arctic species & 12 & 0.5 \\
\hline 27. 4 boreal species $+H$. arctica & 2 & 0.0 \\
\hline 28. 4 boreal species $+M$ truncata & 2 & 0.0 \\
\hline 29. 4 boreal species + H.a. \& M.t. & 2 & 0.0 \\
\hline 30. 4 boreal species $+M$. pseudoarenaria & 1 & 0.0 \\
\hline 31. 4 boreal species + other arctic species & 6 & 0.2 \\
\hline 32. 6 boreal species $+H$. arctica & 2 & 0.0 \\
\hline 33. 6 boreal species $+M$. truncata & 1 & 0.0 \\
\hline Diverse boreal assemblages with arctic species & 16 & 0.6 \\
\hline Boreal assemblages with arctic species (BA) & 41 & 1.7 \\
\hline 34. Boreal species only (B) & 396 & 16.1 \\
\hline $\begin{array}{l}\text { 35. Boreal assemblage with a Virginian } \\
\text { species (BV) }\end{array}$ & 3 & 0.1 \\
\hline $\begin{array}{l}\text { 36. Virginian assemblage with a boreal and } \\
\text { an arctic species (mixed population?) }\end{array}$ & 1 & 0.0 \\
\hline 37. Virginian assemblage (V) & 29 & 1.2 \\
\hline Total classified in assemblages & 2465 & \\
\hline 38. Widespread & 115 & \\
\hline 39. Not identified & 503 & \\
\hline Total & 3083 & \\
\hline
\end{tabular}

Note: the \pm symbol above stands for 'with or without'. with the Radiocarbon Dating Laboratory, Geological Survey of Canada.

All taxa identified and dated are listed in the Appendix along with information on current geographic ranges and synonymy. Addition of reported but undated taxa would increase the list by a few percent. In total 170 shelled taxa have a dated tossil record, with most identified to species. These include 160 molluscs - 47 gastropods and 113 pelecypods - 7 cirripeds, 1 brachiopod, and 3 echinoderms. Although gastropods comprise $27 \%$ of the list, they are mainly from southeastern sample sites. Gastropods appear to be a less prominent part of marine invertebrate faunas in the Arctic. Thorson (1933) found they make $\mu p<1 \%$ of biomass weight in Frans Joseph Fjord, East Greenland. Similarly, Dale (1992) found that gastropods accounted for $<10 \%$ of taxa collected in Pangnirtung Fiord, Battin Island.

\section{FOSSIL MOLLUSC ASSEMBLAGES}

Marine mollusc and mollusc-cirriped assemblages are classified in this paper as widespread, arctic, boreal, temperate (Virginian), or intergrades of these according to geographic ranges (Appendix) and within-sample diversity. Classification was conducted at two levels. A detailed (39-part) classification (Table I) is retained in the database. This was collapsed to a more general classification (see below) for mapping and interpreting environments at a continental scale.

The assemblages defined here are based on the most common groupings that can be discerned from within-sample lists of fossils. They do not necessarily have formally recognized modern counterparts, but our approach does not differ fundamentally from that used in defining modern associations, which are based on relative abundance and diversity at a site. Ideally one should use abundance of species within each sample of fossils to classify that sample, but the database is not sufficiently detailed for this approach. Instead, we use diversity within a sampie and relative abundance within groups of samples to characterize assemblages. Hence, assemblages are discussed below according to a gradient of diversity and, we believe, generally of water-mass temperature.

\section{RESTRICTED ARCTIC ASSEMBLAGE (RA)}

Despite the large number (170) of taxa identified, samples are dominantly of arctic assemblages with few species (Table l; Plates I and II i.lustrate the 15 most common species). By far the most abundantly dated molluscs are Hiatella arctica and Mya truncata, which account for $47.4 \%$ of records. Of the 1168 samples reporting only these species, $H$. arctica occurs in $69.2 \%$ and $M$. truncata in $53.8 \%$. Dominance of the overall record by an apparently low-diversity arctic fauna partly reflects under-reporting of ofher species by submitters of radiocarbon samples, who may have no particular paleontological interests.

Both species range throughout the Arctic and subarctic, submerging to cooier water southward. They inhabit a wide range of depths from intertidal to hundreds of metres but prefer shallow sites, $2-45 \mathrm{~m}$ depth, in arctic waters. $H$. arctica exhibits a wide range of habitat adaptations. This suspension feeder is capable of infaunal habits by boring into soft rock 
and sediment or of epifaunal habits by byssate attachment to clasts. It thus occurs as a fossil in various sediments which partly explains its abundance. $M$. truncata, the most widespread species of its genus, exhibits a narrower range of habitats. This burrowing, infaunal, suspension feeder prefers finer substrates of the upper sublittoral. As a fossil in the Arctic, it is most commonly collected from deltaic and sandy foreshore facies.

No known zoogeographic region today is characterized exclusively by these two molluscs (Lubinsky, 1980). However, many fossil sites, certainly those in deglacial marine sediments in the Canadian High Arctic (Dyke, unpublished observations), Spitsbergen (Feyling-Hanssen, 1955; FeylingHanssen and Olssen, 1960), Greenland (e.g. Bennike, 1987), and apparently many in deglacial sediments south to the Gulf of St. Lawrence, contain only these two molluscs. Therefore, we suggest that this restricted assemblage is a legitimate paleontological group whose distribution is albeit exaggerated by incomplete site inventories of fossils. Hillaire-Marcel (1980) suggested that the $H$. arctica - $M$. truncata association of the Champlain Sea indicates cold waters $\left(<0^{\circ} \mathrm{C}\right)$ and salinities $>30$ per mil in depths greater than $30 \mathrm{~m}$. This depth constraint would not apply to arctic sites.

The greater reported abundance of $H$. arctica than of $M$. truncata in this group agrees with the authors' field experience for arctic sites and accords with the broader range of habitats of $H$. arctica. This relative abundance cannot be explained by different preservation potentials or by a sampling bias for radiocarbon dating because the less-reported $M$. truncata has a larger shell and would tend to be favoured for both reasons.

Another commonly occurring species is included in this group. Portlandia arctica is an obligate arctic species, especially in shallow water. This burrowing deposit feeder is a common fossil of fine-grained, ice-proximal glaciomarine sediment that accumulated in turbid, brackish water; a so-calied facies fauna. It occurs in $3.7 \%$ of identified samples and $7.2 \%$ of samples in the restricted arctic group, commonly alone. In a detailed (regional) analysis it should be considered another restricted arctic assemblage and this distinction is retained in the database. But because its distribution reflects local (substrate) rather that regional environments, we included it in a broader grouping. Its most common associates are Yoldiella fraterna and $Y$. frigida. $P$. arctica siliqua can indicate more boreal conditions but is rarely distinguished in fossil collections.

\section{DIVERSE ARCTIC ASSEMBLAGE (DA)}

A more diverse community appeared in arctic areas shortly atter deglaciation (Lemmen et al, 1994a; Bennike, 1987; Dyke, unpublished). In the High Arctic, diversification is marked at most sites first by appearance of Astarte borealis. According to data at hand (Table II), a typical diverse arctic assemblage consists of Macoma calcarea (in $40.6 \%$ of samples), Clinocardium ciliatum (18.7\%), Serripes groenlandicus (13.6\%), Astarte borealis (13.0\%), and Mya pseudoarenaria $(7.4 \%)$, along with the barnacie Balanus balanus $(6.2 \%)$. However, $M$. truncata and $H$. arctica dominate this assemblage,
TABLE ॥

Taxa in the diverse arctic assemblage (470 samples)

\begin{tabular}{lcc}
\hline Species & No. of & $\%$ \\
& Samples & \\
\hline
\end{tabular}

Gastropods:

Buccinum sp.

Buccinum (hancocki) glaciale

Buccinum physematum

Buccinum (tenuis) scaliforme

Lepeta caeca

Natica clausa

Oenopola sp.

Trichotropis borealis

unidentified gastropods

Pelecypods:

Astarte sp.

Astarte borealis

Astarte crenata

Astarte montagui

Bathyarca glacialis

Bathyarca raridentata

Clinocardium ciliafum

Clinocardium echinatum?

Cytodaria kurriana

Delectopecten greenlandicus

Hiatella arctica

Macoma sp.

Macoma calcarea

Macoma moesta

Musculus sp.

Musculus discors

Musculus niger

Mya sp.

Mya pseudoarenaria

Mya truncata

Mya truncata uddevalensis

Nucula belloti

Nucula sulcata?

Nuculana sp.

Nuculana pernula

Nuculana tenuisulcala

Palliolum greenlandicum

Portlandia sp.

Portlandia arctica

Portlandia intermedia

Serripes groenlandicus

Thyasira sp.

Yoldia hyperborea

Yoldielia fratema

Yoldiella frigida

\begin{tabular}{|c|c|}
\hline 1 & 0.2 \\
\hline 1 & 0.2 \\
\hline 1 & 0.2 \\
\hline 2 & 0.4 \\
\hline 1 & 0.2 \\
\hline 3 & 0.6 \\
\hline 1 & 0.2 \\
\hline 3 & 0.6 \\
\hline 5 & 1.1 \\
\hline 37 & 7.9 \\
\hline 61 & 13.0 \\
\hline 2 & 0.4 \\
\hline 13 & 2.8 \\
\hline 9 & 1.9 \\
\hline 1 & 0.2 \\
\hline 88 & 18.7 \\
\hline 1 & 0.2 \\
\hline 4 & 0.9 \\
\hline 1 & 0.2 \\
\hline 240 & 51.1 \\
\hline 34 & 7.2 \\
\hline 191 & 40.6 \\
\hline 1 & 0.2 \\
\hline 1 & 0.2 \\
\hline 1 & 0.2 \\
\hline 1 & 0.2 \\
\hline 18 & 3.8 \\
\hline 35 & 7.4 \\
\hline 250 & 53.2 \\
\hline 4 & 0.9 \\
\hline 3 & 0.6 \\
\hline 1 & 0.2 \\
\hline 1 & 0.2 \\
\hline 3 & 0.6 \\
\hline 1 & 0.2 \\
\hline 1 & 0.2 \\
\hline 3 & 0.6 \\
\hline 34 & 7.2 \\
\hline 1 & 0.2 \\
\hline 64 & 13.6 \\
\hline 3 & 0.6 \\
\hline 2 & 0.4 \\
\hline 5 & 1.1 \\
\hline 3 & 0.6 \\
\hline 42 & 8.9 \\
\hline 29 & 6.2 \\
\hline 18 & 3.8 \\
\hline
\end{tabular}

Cirripeds:

Balanus sp.

Balanus balanus

Balanus crenatus

Brachiopods:

Hemithyris psiltaceae

.2

0.4

0.2

0.6

6

1.1

7.9

0 6 
occurring in $53.2 \%$ and $51.1 \%$ of samples, respectively. This diverse assemblage is most commonly recovered from deltaic and prodeltaic sediments, which accounts for the nearly equal abundance of $M$. truncata and $H$. arctica.

Mya pseudoarenaria, considered in more detail below, is presently a low arctic mollusc that was formerly more widespread. Today it inhabits shallow water, 2-30 m deep, in eastern Hudson Bay. As a fossil, it usually occurs in diverse arctic associations or in boreal-arctic mixtures. The other prominent taxa of this assemblage are panarctic. The diverse arctic assemblage accounts for $19.1 \%$ of classified records. Future research will likely define important regional variants within this assemblage.

In contrast to the dominant taxa listed above, $62.5 \%$ of the elements in Table II occur in $<1 \%$ of samples. Restricted and diverse arctic assemblages together account for $70.1 \%$ of the database (Table 1).

\section{ARCTIC ASSEMBLAGE WITH BOREAL SPECIES (AB)}

Nearly $82 \%$ of the database consists of arctic-dominated assemblages. Nearly $11 \%$ is an arctic assemblage with boreal species. However, only one boreal species occurs in $80 \%$ of these samples. The samples form two main groups: a northern and a southeastern group.

The northern samples (Table IIIA) are from sites near the present arctic-subarctic marine boundary and within its zone of postglacial oscillation. Samples are mostly diverse arctic assemblages, as described above, to which are added most commonly Mytilus edulis (48.6\% of samples), Chlamys islandica (31.8\%), Macoma balthica (13.3\%), Astarte (montagui) striata (8.1\%), and Mya arenaria (8.1\%). These are the only boreal species that occur in $>5 \%$ of samples. Near their northern limits they are restricted to shallow water. As mentioned above, it would be woth re-examining the $M$. arenaria specimens in this group of samples to see if some are $M$. pseudoarenaria.

The southeastern samples (Table IIIB), from sites withir present boreal and low subarctic waters, similarly are diverse arctic assemblages, to which are added most commonly, Macoma balthica (43.2\%), Mytilus edulis (27.3\%), Mya arenaria $(18.2 \%)$, Chlamys islandica $(9.1 \%)$, and Balanus hameri $(6.8 \%)$. Again these are the only boreal species that occur in $>5 \%$ of samples.

Both regional, arctic-dominated associations are similar in the major species included. But they differ in order of abundance of these species. As might be expected, the southeastern group also has a more diversified overall assemblage (Table IIIB). Hence, early postglacial, arctic-dominated assemblages in the southeast are not strictly analogous to modern or Holocene assemblages near the subarctic-arctic boundary in that they included more temperate elements. Boreal species that occur in the poorly represented (5 samples) early postglacial, arctic-dominated assemblages of the Pacitic include Colus halli, Chlamys rubida, Cyclocardia ventricosa, Macoma obliqua, and, Nuculana fossa.

\section{BOREAL ASSEMBLAGE WITH ARCTIC SPECIES (BA)}

A dominantly boreal assemblage with arctic species comprises only $1.7 \%$ of the database, 41 samples (Table I). Hiatella arctica and Mya truncata are the only arctic species reported in $75 \%$ of these samples. In that these species range throughout the subarctic today, their presence does not necessarily represent strong polar water influence. The five most

TABLE III

Boreal species in arctic-dominated assemblages

\begin{tabular}{ll}
\hline Species & $\begin{array}{c}\text { No. of } \\
\text { Samples }\end{array}$ \\
\hline
\end{tabular}

A. Northern and northeastern region - Amundsen Gulf to northern Labrador and Hudson Bay (173 samples)

Gastropods:

Buccinum undalum $\quad 2 \quad 1.2$

Littorina saxatilis

Trichofrophis borealis

$3 \quad 1.7$

Pelecypods:

Astarte elliptica

Astarte (montagui) striata

Chlamys islandica

Crenella decussata

Lyonsia hyalina

Macoma balthica

Mya arenaria

Mytilus edulis

Nucula delphinodonta

Nucula tenuis

Zirphaea crispata

10.6

Cirripeds:

Balanus balanoides $\quad 3 \quad 1.7$

Balanus hameri

5

2.9

B. Southeastern region - southern Labrador to Maine (88 samples)

Gastropods:

Boreotrophon iruncatus $\quad 1 \quad 1.1$

Buccinum undatum

Buccinum totteni?

Haminoea solitaria

Neptunia despecta fornata

Plicifusus kroyeri

Trichoirophis borealis

Pelecypods:

Astarte undata

Cerastodema pinnulatum

Chlamys islandica

Cyclocardia borealis

Cyrtodaria siliqua

Macoma balthica

Mya arenaria

Mytilus edulis

Nucula tenuis

Panomya arctica

Panopea norvegla?

Spisula sp.

Thyasira sp.

$\begin{array}{rr}5 & 2.9 \\ 14 & 8.1 \\ 55 & 31.8 \\ 2 & 1.2 \\ 1 & 0.6 \\ 23 & 13.3 \\ 14 & 8.1 \\ 84 & 48.6 \\ 1 & 0.6 \\ 3 & 1.7 \\ 2 & 1.2 \\ & \\ 3 & 1.7 \\ 5 & 2.9\end{array}$

Cirripeds:

Balanus hameri 
commonly reported boreal species in this assemblage from the Atlantic are Mytilus edulis (in $69.2 \%$ of samples), Macoma balthica (46.2\%), Chlamys islandica (35.9\%), Mya arenaria $(25.6 \%)$, and Balanus hameri (15.4\%; Table IV). Compared to the arctic assemblage with boreal species, this assemblage is characterized by strong increases in the epifaunal $M$. edulis (to clear dominance), $M$. balthica, and $M$. arenaria. Although this small inter-grade assemblage could be considered fully boreal and the prominence of $M$. edulis distinguishes it from "colder" assemblages, the still-abundant $H$. arctica and $M$. truncata distinguish it from the group here classified as fully boreal. Only two samples of this assemblage are known from the Pacific.

\section{BOREAL ASSEMBLAGE (B)}

The boreal assemblage comprises $16.1 \%$ of the database, 396 samples (Table I). In the Atlantic, only five species occur in $>5 \%$ of samples. In order of abundance, these are Mytilus edulis (37.9\% of samples), Macoma balthica (21.5\%), Mya arenaria $(13.6 \%)$, Balanus hameri $(7.8 \%)$, and Chlamys islandica (5.6\%; Table V). This group of most abundant

TABLE IV

Boreal species in boreal assemblages with arctic elements in the Atlantic (39 samples)

\begin{tabular}{lcr}
\hline Boreal species & $\begin{array}{c}\text { No. of } \\
\text { samples }\end{array}$ & \\
\hline Gastropods: & & \\
Acmaea testudinalis & 1 & 2.6 \\
Buccinum undatum & 2 & 5.1 \\
Lacuna vincta & 1 & 2.6 \\
Littorina oblusata & 1 & 2.6 \\
Nucella lapellis & 1 & 2.6 \\
Pelecypods: & & \\
Astarte crenata subaequilatera & & \\
Astarte montagui & 4 & 10.3 \\
Astarte striata & 5 & 12.8 \\
Chlamys islandica & 2 & 5.1 \\
Cyclocardia borealis & 14 & 35.9 \\
Cyrtodaria siliqua & 3 & 7.7 \\
Ensis directus & 4 & 10.3 \\
Macoma balthica & 3 & 7.7 \\
Mesodesma arctatum & 8 & 46.2 \\
Mesodesma deauratum & 4 & 10.3 \\
Mya arenaria & 1 & 2.6 \\
Mysella planulata & 10 & 25.6 \\
Mytilus edulis & 1 & 2.6 \\
Panomya arctica & 27 & 69.2 \\
Spisula polynyma & 2 & 5.1 \\
Spisula solidissima & 3 & 7.7 \\
Thracia septentrionalis & 1 & 2.6 \\
Zirphaea crispata & 1 & 2.6 \\
Cirripeds: & 2 & 5.1 \\
Balanus balanoides & & \\
Balanus hameri & 1 & 2.6 \\
Brachiopods: & 6.4 \\
Hemithyris psittacea & & \\
\hline & 5 & 12.8 \\
\hline
\end{tabular}

species is nearly identical to the group of most abundant boreal animals in the boreal assemblage with arctic species; the two most common animals are the same in both groups. However, in the boreal assemblage, $C$. islandica

TABLE V

Taxa in boreal assemblages (396 samples)

\begin{tabular}{|c|c|c|}
\hline Species & $\begin{array}{c}\text { No. of } \\
\text { samples }\end{array}$ & $\%$ \\
\hline
\end{tabular}

Attantic

Gastropods:

Buccinum undatum $\quad 7 \quad 1.8$

Littorina littorea

Littorina obtusata

Littorina saxatilis

Neptunea despecta tornata

Nucella lapillus

Thais lapillus

Pelecypods:

Arctica islandica

Astarte crenata subaequilatera

Astarte montagui striata

Astarte undata

Chlamys islandica

Cyclocardia borealis

Ensis directus

Macoma balthica

Mercenaria mercenaria

Mesodesma arctatum

Modiolus modiofus

Mya arenaria

Mylilus edulis

Nucella delphinodonta

Nucula proxima

Nucula tenuis

Nuculana minuta

Panopea norvegia

Placopecten magellanicus

Soisula polynyma

Spisula solidisima

Zirphaea crispata

Cirripeds:

Balanus hamer

Brachiopod:

Hemithyris psittacea

0.2

10.2

$\begin{array}{ll}1 & 0.2 \\ 1 & 0.2\end{array}$

0.2

$6 \quad 1.5$

30.8

Pacific

Gastropods:

Fusitron oregonensis

Thais lamellosa

Pelecypods:

Chlamys rubida

Clinocardium nutalli

Macoma brota

Macoma inquinata

Macoma liparia

Macoma nasuta

Mytilus sp.

Ostrea lirida

Pododesmus macroschisma

Saxidomus gigantea 
declines in rank whereas $M$. arenaria and $B$. hameri increase. Many boreal species are represented in this fossil record by occurrence in one sample. Saxidomus gigantea is the most common boreal species reported from the Pacific.

\section{VIRGINIAN ASSEMBLAGE $(V)$}

The Virginian assemblage comprises only $1.2 \%$ of the database. In the Atlantic it consists most commonly of oyster, Crassostrea virginica, communities (75\% of samples; Table VI). Virginian taxa today range into the Bay of Fundy and the southwestern Gulf of St. Lawrence. That region has submerged during the Holocene which militates against fossil recovery. The temperate assemblage in the Pacific is represented by only five samples, two of which contain the mussel Mytilus californianus.

\section{REPRESENTATIVENESS OF FOSSIL ASSEMBLAGES}

The Late Quaternary marine fossil record is clearly dominated by only 15 species, 14 of which are molluscs (Table VII; Plates I and II). Most of the other 155 recorded taxa, generally $70-80 \%$ of taxa, are reported in $<5 \%$ of samples (Tables $(1-V)$ and many are single occurrences. This raises the question of how representative this particular fossil record is of its contemporaneous environments.

One approach to addressing this question lies in examining the sharing of rare species among the various assemblages. Take "rare" to be species listed as single occurrences or very low percentages where sample size is large (Tables II-VI). The number of rare species is similar in each assemblage, and with one exception, well over half of these occur uniquely in their groups (Table VIII). In this view, even the rare species are "representative" of the environmental categories here erected. Except in the odd case where a rare species is the only one in a sample, they have not themselves determined the classifications of the samples.

TABLE VI

Species in Virginian (temperate) assemblages

\begin{tabular}{lll}
\hline Species & No. of \\
Samples & $\%$ \\
\hline
\end{tabular}

\section{A. Atlantic (24 samples)}

Gastropods:

Polinices heros

14.2

Pelecypods:

Crassostrea virginica

Gukensia demissa

Mercenaria mercenaria

Pecten irradians

Spisula solidissima

B. Pacific (5 samples)

Pelecypods:

Hinrites multirugosus

Mytilus californianus

Protothaca tenerrima

Solen sicarius
TABLE VII

The top 15 marine invertebrates - percentage reported occurrences in assemblages (see footnote for definitions)

\begin{tabular}{lrrrrrrr}
\hline & $\mathrm{RA}$ & $\mathrm{DA}$ & $\mathrm{AB} \cap$ & $\mathrm{ABs}$ & $\mathrm{BA}$ & $\mathrm{B}$ & $\mathrm{V}$ \\
\hline H. arctica & 64 & $\mathbf{4 3}$ & $\mathbf{8 1}$ & $\mathbf{7 4}$ & $\mathbf{6 2}$ & 0 & 0 \\
M. truncata & 50 & $\mathbf{4 5}$ & 77 & $\mathbf{5 0}$ & $\mathbf{4 6}$ & 0 & 0 \\
P. arctica & 7 & 7 & 2 & $\mathbf{1 6}$ & 3 & 0 & 0 \\
M. calcarea & 0 & 41 & $\mathbf{3 4}$ & $\mathbf{3 5}$ & 5 & 0 & 0 \\
C. ciliatum & 0 & 19 & 17 & 8 & 0 & 0 & 0 \\
S. groenlandicus & 0 & 14 & 15 & 11 & 3 & 0 & 0 \\
A. borealis & 0 & 13 & 6 & 2 & 3 & 0 & 0 \\
M. pseudoarenaria & 0 & 7 & 4 & 8 & 8 & 0 & 0 \\
M. edulis & 0 & 0 & 49 & $\mathbf{2 7}$ & 69 & 38 & 0 \\
C. islandica & 0 & 0 & $\mathbf{3 2}$ & $\mathbf{9}$ & 36 & 6 & 0 \\
M. balthica & 0 & 0 & 13 & $\mathbf{4 3}$ & $\mathbf{4 6}$ & $\mathbf{2 2}$ & 0 \\
A. striata & 0 & 0 & 8 & 0 & 5 & 0 & 0 \\
M. arenaria & 0 & 0 & 8 & 18 & 26 & $\mathbf{1 4}$ & 0 \\
B. hameri & 0 & 0 & 3 & 7 & 15 & 8 & 0 \\
C. virginica & 0 & 0 & 0 & 0 & 0 & 0 & 75 \\
\hline
\end{tabular}

RA: restricted arctic; DA: diverse arctic: ABn: arctic with boreal elements, nothem areas; ABs: arctic with boreal elements, southeastern areas (not an extant environment); BA: boreal with arctic elements; B: boreal; and V: Virginian.

Note: Other than the 15 species listed above, the only taxa prominently represented in the fossil record are the widespread barnacles, which occur in $66 \%$ of samples classified as "widespread" (115 samples) and are also common in all environmental groups other than RA. in the samples with widespread taxa only, $31 \%$ record Balanus sp., $22 \%$ B. balanus, and $13 \%$ B. crenalus.

TABLE VIII

Sharing of rare species of marine molluscs among assemblages

\begin{tabular}{lcccc}
\hline Assemblage & $\begin{array}{c}\text { Rare } \\
\text { Species }\end{array}$ & $\begin{array}{c}\text { Shared } \\
1 \text { other }\end{array}$ & $\begin{array}{c}\text { Shared } \\
>1 \text { other }\end{array}$ & $\begin{array}{c}\% \\
\text { Shared }\end{array}$ \\
\hline Diverse arctic & 16 & 0 & 1 & 6.3 \\
Arctic-boreal, N & 13 & 1 & 3 & 30.8 \\
Arctic-boreal, SE & 8 & 1 & 4 & 62.5 \\
Boreal-arctic & 12 & 1 & 3 & 33.3 \\
Boreal & 18 & 2 & 3 & 27.8 \\
Virginian & 5 & 1 & 1 & 40.0 \\
\hline
\end{tabular}

Another approach is simply to measure "inclusiveness" by comparing regional lists of modem marine invertebrates with the list of fossils. Two major compilations cover most of our fossil sample sites. Bousfield (1960) described marine invertebrates occurring in the Atlantic Provinces region but most of these range welt beyond there. He listed 51 gastropod species, $14(27.5 \%)$ of which are represented in the fossil database; 32 of 55 pelecypod species (58.2\%) are represented, 4 of 6 cirripeds, 2 of 5 echinoderms, and 1 of 2 brachiopods. About $50 \%$ of the missing gastropods and pelecypods range minimally into the region from the south, moreover into a region of Holocene submergence. This can largely account for their absence from the current fossil record, which is reasonably inclusive with respect to more wide ranging species. Still, 
one suspects a more serious under-representation of gastropods than of pelecypods. Several species listed for Atlantic Canada but not represented in our list of fossils build thin, fragile, translucent shells (e.g. Velutina laevigata, Skenea planorbis, Mitrella lunata, Margarites costalis).

Lubinsky (1980) presented a comprehensive list of pelecypods in the Canadian Arctic Archipelago and mainland south to Strait of Belle Isle. Of the 64 species listed, 41 $(64.1 \%)$ are reported as fossils. Of the 23 unrepresented species, 11 are described as rare in the Canadian Arctic, some have single, unconfirmed reports, some have depth ranges that make them unlikely fossil exposures in postglacial raised marine deposits, and others range marginally into the region of postglacial emergence from the Beaufort Sea. Thus, the current fossil list includes about $75 \%$ of more common nearshore species. The data of Valentine (1989) and Aitken (1990) discussed above, collected to assess the representativeness of the fossil record, suggest that the record that we use here is reasonably inclusive.

However, considerations of inclusiveness do not address the question of whether the relative abundances of fossils reasonably reflect abundances of animals in the former communities, In particular, it would be useful to know whether the 15 abundant species (Table VII) dominate the various nearshore environments in rough proportion to their reported fossil abundance. The paucity of quantitative inventories of molluscs in the wide range of Canadian cold-water environments makes this difficult to assess.

\section{FOSSIL MOLLUSC ASSEMBLAGES AND MODERN FAUNISTIC ZONES}

Our database is dominated by arctic and subarctic assemblages of molluscs, primarily bivalves, as would be expected from the general paleoenvironmental conditions. Therefore, we use here the terminology and definition of bivalve zones of Lubinsky (1980) who treats the arctic, subarctic, and adjoining boreal zones in sufficient detail for our purposes. She based her classification and zoogeographic subdivisions on bivalves particular to cold, primarily shallow, waters. As discussed above, no modern faunal zone corresponds to the restricted arctic assemblage consisting of Hiatella arctica and Mya truncata only. Such a zone existed in ice-proximal waters during deglaciation, but many samples classified here as restricted arctic would be reclassified if fossil inventories were more completely reported. Most would likely fall into the diverse arctic group.

The diverse arctic fossil assemblage corresponds in composition closely to most of Lubinsky's (1980, p. 57-62) High Arctic Faunistic Subzone (Arctic Zone). Specifically, it corresponds to her subdivisions I, II, and IV, which include most of the Arctic Archipelago south to Cape Dyer. This zone is dominated entirely by polar surface water from the Arctic Ocean; it lies north of the farthest penetration of subarctic waters. Sea-ice cover persists for 7-12 months a year, resulting in mostly negative water temperatures. The upper 50 $100 \mathrm{~m}$ of water, corresponding to depths represented by most fossils, exhibits slight seasonal variability with summer water temperatures rising to $0-5^{\circ} \mathrm{C}$ (Lubinsky, 1980). This region lacks vertical zonation of faunas because warming is insufficient for survival of the hardiest of more southern species.

Our fossil arctic assemblage with boreal species, as represented by samples from northern sites (Table IIIA), corresponds to Lubinsky's subdivision III of the High Arctic Faunistic Subzone (the southwestern archipelago and adjacent mainland coast), to her Low-Arctic Faunistic Subzone (Hudson and James bays) and to the northernmost subdivision of her Subarctic Faunistic Zone (Hudson Strait to Cape Dyer). In these areas of polar surface water, with minimal admixture of other waters, the littoral zone is warmed enough seasonally for subarctic-boreal species to survive. Hence, these are the northernmost areas that exhibit a vertical thermal and faunal zonation. Its northern boundary corresponds essentially to that of the marine subarctic of Dunbar (1968). Those subarctic-boreal species in the southwestern archipelago extend from the Pacific via the Beaufort Sea; Beaufort Shelf Water is warmer and less saline than Arctic Ocean Surface Water due to Mackenzie River discharge.

As mentioned above, that part of the arctic assemblage with boreal elements as represented by samples from southeastern sites (Table IIIB) lacks a strict modern analog. We infer that these probably reflect the extra seasonal warming of littoral waters to be expected in more southerly areas. Because of this, more thermophilous species were viable but warming did not proceed to the point that would have prevented arctic fauna from dominating in relatively shallow water.

The fossil boreal assemblage with arctic species resembles that found today in mixed polar and Atlantic waters between eastern Newfoundland and the north shore of the Gulf of St. Lawrence in the south and Hudson Strait in the north. It thus corresponds most closely to Lubinsky's Subarctic Faunistic Zone, particularly to southern Labrador (subdivision VII), which today shows the first marked increase southward in species diversity, and to her Northern Acadian Faunistic Subzone, which shows a further increase in diversity. These areas are influenced strongly by the Labrador Current but seasonal warming and advection of non-polar water yields a warm surface layer thick enough that borealsubarctic species occupy littoral and sublittoral vertical zones. Summer surface water temperatures remain below $12^{\circ} \mathrm{C}$. Arctic elements are restricted to species like Hiatella arctica and Mya truncata that have greater tolerances for relatively warm water. Lubinsky (1980) suggested that they acquired these tolerances during southward displacements at glacial maxima.

Our boreal assemblage resembles that found in the Gulf of St. Lawrence region, the Acadian Faunistic Zone. Summer sea surface temperatures in this region are $12-15^{\circ} \mathrm{C}$. Bousfield (1960) classifies the constituent molluscs, which dominate the Atlantic Provinces fauna, as boreal or cold-temperate. Most member species range mainly between southern Labrador and North Carolina. Solar heating and incursion of warm Atlantic water resulted in exclusion of arctic species within sampled paleo-water depths (up to about $150 \mathrm{~m}$ ). Arctic species need water below $10^{\circ} \mathrm{C}$ for reproduction and do not survive where summer temperatures exceed 
$20^{\circ} \mathrm{C}$; optimum temperatures for reproduction of boreal species lie mostly between $5^{\circ}$ and $15^{\circ} \mathrm{C}$ (Bousfield, 1960).

The Virginian fossil assemblage corresponds to the present temperate or Virginian Faunistic Zone where summer surface water temperatures exceed $18^{\circ} \mathrm{C}$. However, Virginian species extend into the southern Acadian Faunistic Zone. In Atlantic Canada and adjacent USA, this zone is one of warm waters resulting either from exceptional seasonal warming or from incursion of Gulf Stream water. Virginian taxa today range from the Gulf of Mexico to the Bay of Fundy and southwestern Gulf of St. Lawrence, although they are interrupted by a large cold-water gap in the Gulf of Maine. These animals require high temperatures for reproduction, $20^{\circ} \mathrm{C}$ in the case of the oyster, the most numerous fossil in this assemblage (Bousfield, 1960).

\section{REGIONAL TIME SERIES OF MOLLUSC ASSEMBLAGES}

In this section we examine frequency distributions of mollusc assemblages through time for sixteen regions (Fig. 2) that conform generally to (but extend) Lubinsky's (1980) faunistic provinces. The discussion proceeds generally from the warmest region to the coldest in the east and then to the Pacific after a discussion of the aggregate frequency distribution of radiocarbon dates.

\section{AGGREGATE FREQUENCY DISTRIBUTION OF DATES}

Several factors conspire to generate an uneven frequency distribution of dates on marine shells for northern North America (Fig. 3). An obvious one is the extent of glacier ice cover. The dates do not extend all the way back to the last glacial maximum at $18 \mathrm{ka} \mathrm{BP}$. Fossils of that age can only be

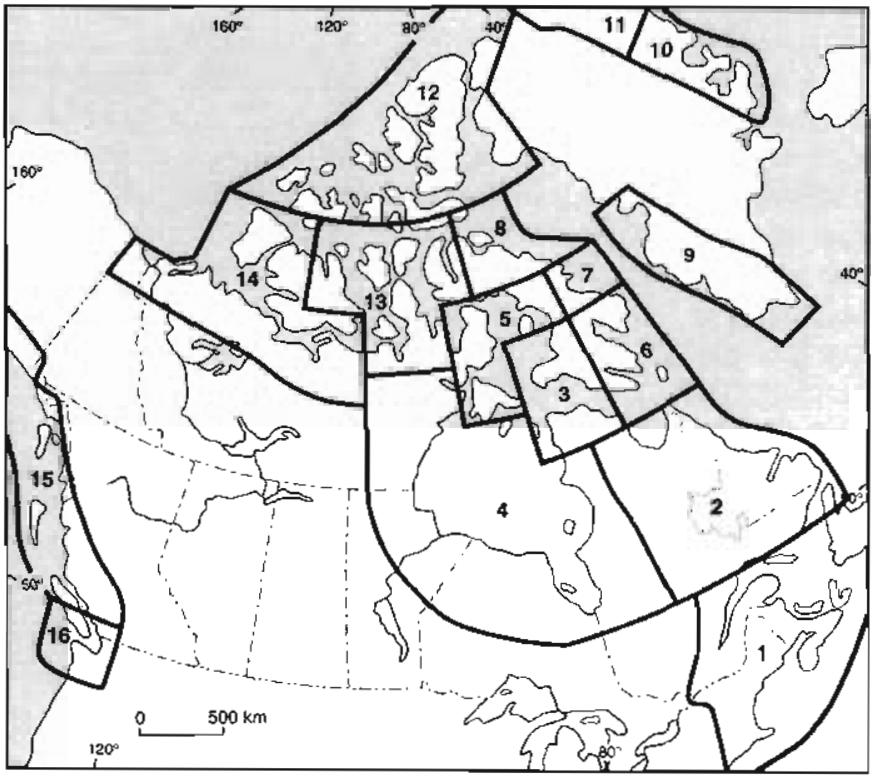

FIGURE 2. Regions for which histograms of mollusc assemblages are presented. Names are provided in the text.

Carte des régions pour lesquelles les histogrammes de tréquence des assemblages de mollusques ont eté preparés. Les noms apparaissent dans le texte. found beyond the glacial limit and below the glacial maximum shorelines which are now generally submerged by $100-120 \mathrm{~m}$. Few samples are older than $14 \mathrm{ka} B P$. The strong increase in number of samples dating $14-9 \mathrm{ka}$ BP correlates with a progressive increase in extent of postglacial seas. However, these seas continued to increase until about $6 \mathrm{ka}$ BP. For example, Hudson Bay and Foxe Basin were deglaciated 8 $6.5 \mathrm{ka} \mathrm{BP}$. Hence, the steady decline in number of samples dating $<9 \mathrm{ka} \mathrm{BP}$ is not easy to explain. The relatively few samples dated <6 ka BP probably reflects lessened interest in dating late Holocene marine features and the progressive decrease in area occupied by younger raised marine sediments. But perhaps there are biological influences on the distribution of dates (Fig. 3); the dynamic deglacial environment 10-7 ka BP, with its high meltwater flux and water mass turnover, may have created a greater number and variety of habitats attractive to molluscs while high sedimentation rates enhanced preservation. The practical implication of the distribution in Figure 3 for the present analysis is that the different time intervals are unevenly rich in data. The impoverishment in late Holocene data is unfortunate in that this time provides the best means of linking the fossil record, particularly in terms of representativeness, with modern zoogeography.

\section{GULF OF MAINE - GULF OF ST LAWRENCE}

The Gulf of Maine - Gulf of St. Lawrence region as used here (\#1 in Fig. 2) includes the former Champlain Sea. The region, roughly the modern Acadian Faunistic Zone, has richly dated Late Wisconsinan marine faunas but poorly dated Holocene faunas (Fig. 4). This primarily reflects regional sea level history (Grant, 1989). In most of the region, the shoreline regressed to present levels and lower by early Holocene; oniy the northern Gulf of St. Lawrence has an emerged and readily accessible Holocene marine record.

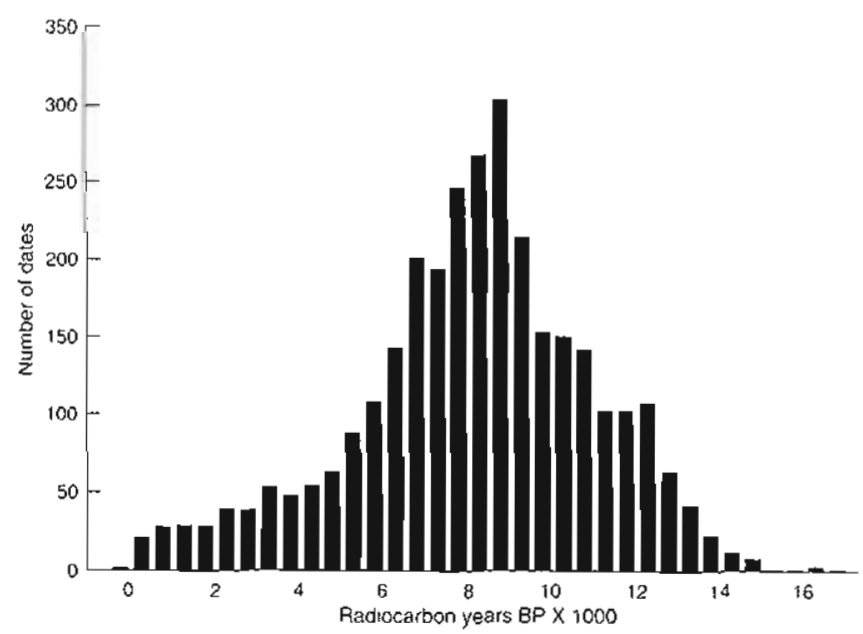

FIGURE 3. Frequency distribution of radiocarbon dates on marine shells north of $40^{\circ} \mathrm{N}$ in North America, including Greenland ( $\left.n=3080\right)$.

Histogramme de fréquence des ages au radiocarbone des coquillages marins au nord du $40^{\circ}$ lat. $N$ en Amerique du Nord et au Groenland $(n=3080)$. 
This region is at the southeastern limit of glaciation where the ice sheet margin must have contacted the warmest waters along its entire eastern side. The earliest faunas, dating close to glacial maximum, were dominantly, but not exclusively, arctic in character. The oldest record (off scale on Fig. 4), is of Portlandia arctica dated $17 \mathrm{ka}$ BP from the Scotian Shelf, but Nucula proxima, which presently ranges from Nova Scotia to Texas, was also present there at $16.3 \mathrm{ka} \mathrm{BP}$. The entire record older than $14 \mathrm{ka} \mathrm{BP}$ consists of 6 samples of $P$. arctica, 3 of Hiatella arctica, 1 of Macoma calcarea, all arctic-subarctic species; single samples of the boreal species $N$. proxima, $N$. tenuis, Mesodesma arctafum, and Balanus hameri, and a sample of the widespread Balanus crenatus.

After ice retreat onshore, the restricted Hiatella arctica Mya truncata assemblage was common throughout the remaining Late Wisconsinan. This assemblage is represented by only two samples after $8.5 \mathrm{ka} \mathrm{BP}$, despite the fact that both molluscs range into the region today. In every 1 ka interval before $8 \mathrm{ka} \mathrm{BP}, H$. arctica outnumbers $M$. truncata by a tactor of 2-4, reflecting its greater substrate adaptability and possibly its more advantageous position at glacial maximum resulting from its greater depth range. The boreal elements noted above at glacial maximum remained the most common early in deglaciation. The ratio of boreal to arctic assemblages increased to boreal dominance about $8.5 \mathrm{ka} \mathrm{BP}$ when there was no longer any glacier ice left in the region. BoreatVirginian taxa are sporadically recorded back to $13.5 \mathrm{ka} \mathrm{BP}$ and are relatively well represented between $11 \mathrm{ka}$ and $3.5 \mathrm{ka}$ $B P$, mainly by Crassostrea virginica. The late Holocene record is entirely boreal as expected for the Acadian Faunistic Zone.

\section{LABRADOR}

This region includes the lower Québec North Shore, both sides of the Strait of Belle Isle, the Labrador coast and Ungava Bay (\#2 in Fig. 2). It thus consists mainly of the southern two provinces of Lubinsky's Subarctic Faunistic Zone. Most of it has experienced continuous postglacial emergence (Vincent, 1989). Its molluscan fauna is fairly well dated and spans the last 13 ka starting with deglaciation of the Strait of Belle Isle area (Fig. 5). The record shows dominantly arctic assemblages before $9 \mathrm{ka} \mathrm{BP}$, a mosaic of boreal, boreal-arctic, and diverse arctic assemblages from $9 \mathrm{ka}$ to $4 \mathrm{ka} \mathrm{BP}$, and mostly boreal assemblages after $4 \mathrm{ka}$.

The lack of prominence of the restricted arctic assemblage here during deglaciation is interesting but may simply reflect better reporting of taxa by regional workers. Boreal species were among the first to enter, including Mytilus edulis by $12.6 \mathrm{ka} \mathrm{BP}$. Cyrtodaria siliqua, Chlamys islandica, and Buccinum undatum followed shortly thereatter ( $>12 \mathrm{ka} \mathrm{BP})$. the first and last of which reach their northern limits here today. The single record classified as Virginian is one of Spisula solidisima at St Anthony, northernmost Newfoundland; its modern range is Nova Scotia to South Carolina. Hence, this record represents a substantial range extension.

\section{HUDSON STRAIT}

This region includes central and western Hudson Strait and adjacent segments of Hudson Bay and Foxe Basin (\#3 in
Fig. 2). It occupies the modern subarctic-arctic transition of Lubinsky (1980). Because this is entirely an area of continuing postglacial emergence, the decline in frequency of dated faunas after $7 \mathrm{ka} \mathrm{BP}$ (Fig. 6) reflects either decreasing faunal abundance, a decrease in deposition of sediments that can host marine fossils, or decreased interest in dating younger deposits. The dated faunal record extends securely back to about $9 \mathrm{ka} \mathrm{BP}$ and more tenuously to nearly $11 \mathrm{ka} \mathrm{BP}$. The suite of dates older than $9 \mathrm{ka} \mathrm{BP}$ is mostly from a thin bed containing Portlandia arctica and Yoldiella fraterna in the bottomsets of a glaciomarine delta. Dates on this bed range from $10.675 \mathrm{ka}$ to $8.51 \mathrm{ka} \mathrm{BP}$ (Gray et al., 1993). The older dates were the basis for the proposed "early" deglaciation of Hudson Strait (e.g. Dyke and Prest, 1987), but the range of dates on this bed is problematic: if all are accepted as valid, it indicates a near zero accumulation rate and unvarying faunal composition in an ice-proximal, glaciomarine deltaic environment for $>2 \mathrm{ka}$. This aside, the pre- $8 \mathrm{ka}$ BP faunas are dominated by the restricted arctic assemblage consisting of the species mentioned plus Hiatella arctica and Mya truncata.

The post- 8 ka BP record demonstrates a dominant mixture of restricted and diverse arctic assemblages but boreal elements are present throughout. The first recorded boreal entry is of Mytilus edulis at $8.04 \mathrm{ka} \mathrm{BP}$. This and four other recorded boreal species range through the region today. However, the barnacle Balanus hameri occurs in three samples dated between $7.83 \mathrm{ka}$ and $7.08 \mathrm{ka} \mathrm{BP}$ but ranges today only north to Hamilton Inlet, thus indicating a range extension of $1100 \mathrm{~km}$. Mya arenaria is reported in a sample dated $7.16 \mathrm{ka}$ $\mathrm{BP}$ and also now has its northern limit at Hamilton Inlet.

\section{HUDSON BAY}

Hudson Bay (\#4 in Fig. 2), which comprises Lubinsky's entire Low Arctic Subzone, is thought to have been deglaciated about $8 \mathrm{ka}$ BP (Andrews and Falconer, 1969; Dyke and Prest, 1987). However, four radiocarbon dates on marine shells, two from Québec (QU-242, 8.55 ka; QU-244, $8.23 \mathrm{ka}$ ) and two from Manitoba (BGS-813, $8.2 \mathrm{ka}$; GX-1063, $8.01 \mathrm{ka})$, suggest that the $8 \mathrm{ka}$ estimate may be conservative. Until 7 ka BP, the Tyrrell Sea (postglacial Hudson Bay) apparently had a low diversity marine molluscan fauna (Fig. 7) consisting of 7 species. Of 40 samples with identified species dating $>7 \mathrm{ka} \mathrm{BP}$, Hiatella arctica occurs in $70 \%$, Macoma calcarea in 22.5\%, Mya truncata in 20\%, Macoma sp. Chlamys islandica, and Clinocardium ciliatum, each in $5 \%$, and Portlandia arctica and Mytilus edulis in single samples (2.5\%). This agrees with Wagner's (1969) high elevation Hiatella-dominated zone. The abundance of $M$. calcarea (especially adding Macoma sp.) relative to $M$. truncata, along with its prolonged presence when other common arctic molIuscs were so rare, is not characteristic of any of the environmental groups in aggregate (Table $\mathrm{V} \mid 1$ ).

The two recorded boreal species dating $>7 \mathrm{ka}$ BP range throughout the bay today and entered soon upon deglaciation (7.88 ka BP). The proportion of samples with boreal elements increased in the interval $7.6 \mathrm{ka}$ BP but may have declined again; sparse dating of middle Holocene faunas leaves this unclear. The increase in boreal elements is due almost en- 

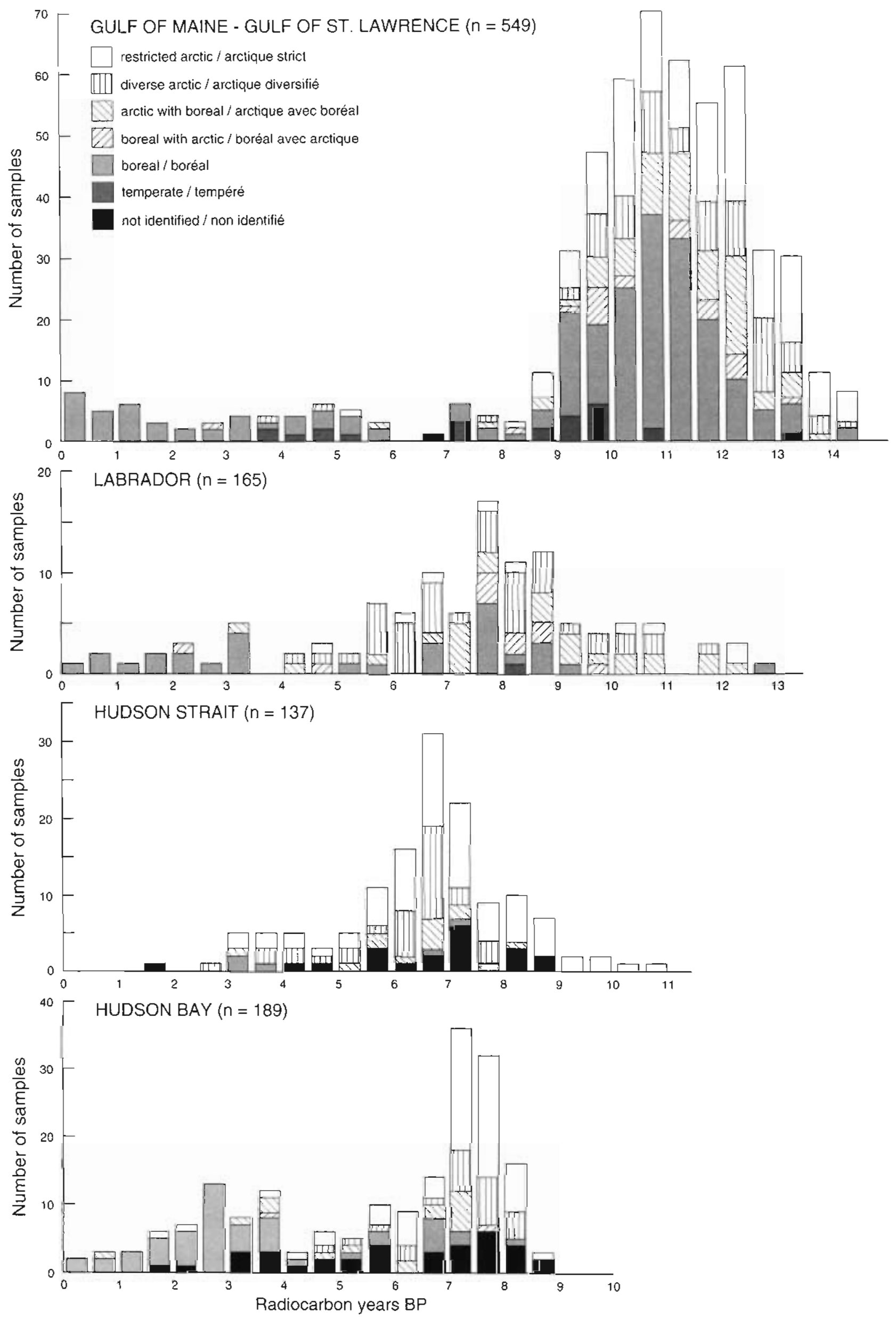

FIGURES 4-7. Frequency distributions of marine mollusc assem- Histogrammes de fréquence des assemblages de mollusques marins 
tirely to Mytilus edulis, which occurs in $33 \%$ of identified samples dating 6-7 ka BP and is the second most recorded species. The first recorded appearance of Macoma balthica is at 6.1 ka BP. Mya pseudoarenaria occurs first in the same sample. The taxa list for 7-6 ka BP increases to 20 , mainly by addition of common arctic species. Hiatella arctica remains strongly dominant ( $71 \%$ of samples), but Macoma calcarea declines to $15.6 \%$, whereas Mya truncata increases to $26.7 \%$.

The late Holocene record is dominated by boreal assemblages, mainly by Mytilus edulis, which occurs in $83 \%$ of identified samples dating $<4 \mathrm{ka} B P$. The taxa list for this interval contains only 14 species. This may reflect a focus on collecting $M$. edulis to date raised beaches because of its intertidal habitat, but it is not clear why this bias is not prevalent in older samples. Lubinsky (1980, p. 54) refers to the "pauperization" of the fauna of James Bay because of uplift (shallowing and freshening). Perhaps the record in Figure 7 reflects a similar process for Hudson basin in general, where deeper water species have become increasingly restricted to small parts of the bay. The only range extension recorded by the Hudson Bay faunal record is that of Mya arenaria in a sample (I-3907) from Cape Henrietta Maria on the south shore dated at $2.41 \mathrm{ka}$ BP; the present limit is at Hamilton Inlet.

\section{FOXE BASIN}

The Foxe Basin region as defined here (\#5 in Fig. 2) includes a part of southern Gulf of Boothia because data were sorted by geographic coordinates. The basin proper probably was not deglaciated until about $6.9 \mathrm{ka} \mathrm{BP}$, the oldest shells dated from there; pre-7 ka samples on Figure 8 are from Gulf of Boothia. The region is within Lubinsky's High Arctic Subzone province IIt, which has the peculiarity of having the least number of mollusc species in the entire Arctic, partly because of shallowness and restricted currents flowing in from the open ocean. Mytilus edulis, Macoma balthica, and Chlamys islandica, common in Hudson Bay, are absent here. This large region of continuous emergence remains inadequately dated and more than half the ages are concentrated in the immediate postglacial interval (Fig. 8). The record may illustrate a postglacial succession from restricted to diverse arctic assemblages, but the poor dating of the middle and late Holocene leaves this uncertain.

Two samples record a boreal species in the basin. Both report Mya arenaria on the western side, the earlier at $6.26 \mathrm{ka}$ $\mathrm{BP}$ (GSC-4798). In light of the large range extension implied and the absence of Mytilus edulis and Chlamys islandica, which are more north-ranging than $M$. arenaria, in both the present fauna and as fossils, these shells are probably Mya pseudoarenaria. The latter is reported from one site on the Baffin shore of the basin (GSC-5395).

The fossil record of Foxe Basin is impoverished with only 13 species, excluding $M$. arenaria. The 7-6 ka BP record, with 9 species, is dominated by Hiatella arctica ( $81.1 \%$ of samples), Mya truncata (40.5\%), and Macoma calcarea (10.8\%), the only species reported in more than one sample. The 6-4 ka $\mathrm{BP}$ record, with 12 species, is more balanced, with $\mathrm{H}$. arctica $(61.5 \%)$, M. truncata $(42.3 \%)$, M. calcarea $(30.8 \%)$, Clinocardium ciliatum (11.5\%), and Serripes groenlandicus
(11.5\%), again the only molluscs in more than one sample. The post- 4 ka record has 9 species dominated by $M$. truncata $(73.3 \%)$, M. calcarea $(26.7 \%)$, S. groenlandicus $(26.7 \%), H$. arctica $(20 \%)$, and C. ciliatum $(13.3 \%)$.

There are interesting contrasts between the fossil records of Hudson Bay and Foxe Basin beyond the northward impoverishment in species. In Hudson Bay, M. calcarea was abundant - more so than $M$. truncata - in the first $1 \mathrm{ka}$ after deglaciation, then decreased as the assemblage diversified. In Foxe Basin, $M$. calcarea was subordinate in the first $1 \mathrm{ka}$ after deglaciation, then increased as the assemblage diversified.

Lubinsky $(1980$, p. 60) pointed out that the subarctic species Crenella faba and Yoldia hyperborea occur in the northern part of Foxe Basin, probably as postglacial relicts. This implies that they extended their ranges into the basin under conditions more favourable than today. As yet these are missing from the fossil record.

\section{SOUTHEAST BAFFIN ISLAND}

This region extends from eastern Hudson Strait to the present northern limit of boreal-subarctic species just north of Cape Dyer (\#6 in Fig. 2). It coincides with Lubinsky's northernmost subarctic province. The faunal record is well dated for the general interval of deglaciation but is almost blank thereafter (Fig. 9). The easternmost parts of the region have experienced middle to late Holocene submergence but the rest has undergone continuous emergence (Andrews, 1989). Hence, the near absence of records younger than $6 \mathrm{ka} \mathrm{BP}$ is not adequately explained by the sea-level history. There is little evidence of ecostratigraphic succession in this record. Thermophiles are present early in deglaciation and there is no evidence of a period when their range retracted south of the region. Chlamys islandica is the most common of these and makes the first recorded appearance ( $9.51 \mathrm{ka} B P$ ), followed by Macoma balthica (8.23 ka BP), Mytilus edulis (7.61 ka BP), Balanus balanoides (7.08 ka BP), and Lyonsia hyalina (6.4 ka BP). Excepting the last, which is a single, unconfirmed and dubious record of a Virginian species, none of these represent range extensions. However, species diversification may have occurred in that only 3 species (Mya truncata, Hiatella arctica, and Balanus balanus) are recorded for the pre-10 ka BP interval, whereas successive $1 \mathrm{ka}$ intervals record 11 species (10-9 ka), 18 species ( $9-8 \mathrm{ka}), 13 \mathrm{spe}-$ cies (8-7 ka), and 18 species $(7-6 \mathrm{ka})$. There are no consistent trends in abundances of the dominant $H$. arctica and $M$. truncata.

\section{HOME BAY}

The Home Bay area of central eastern Baffin Island extends north from the present marine subarctic-arctic boundary (\#7 in Fig. 2). Thus, it is sensitively located to record shifts of this boundary as indicated by range extensions. The dated faunal record extends from 10 to $2.7 \mathrm{ka} \mathrm{BP}$. Boreal-subarctic species apparently extended throughout the Home Bay area for most of that time (Fig. 10). The first to appear was Astarte striata at $9.28 \mathrm{ka} \mathrm{BP}$. It is probably the least warmthdemanding in that it occupies arctic outposts today, but it is 

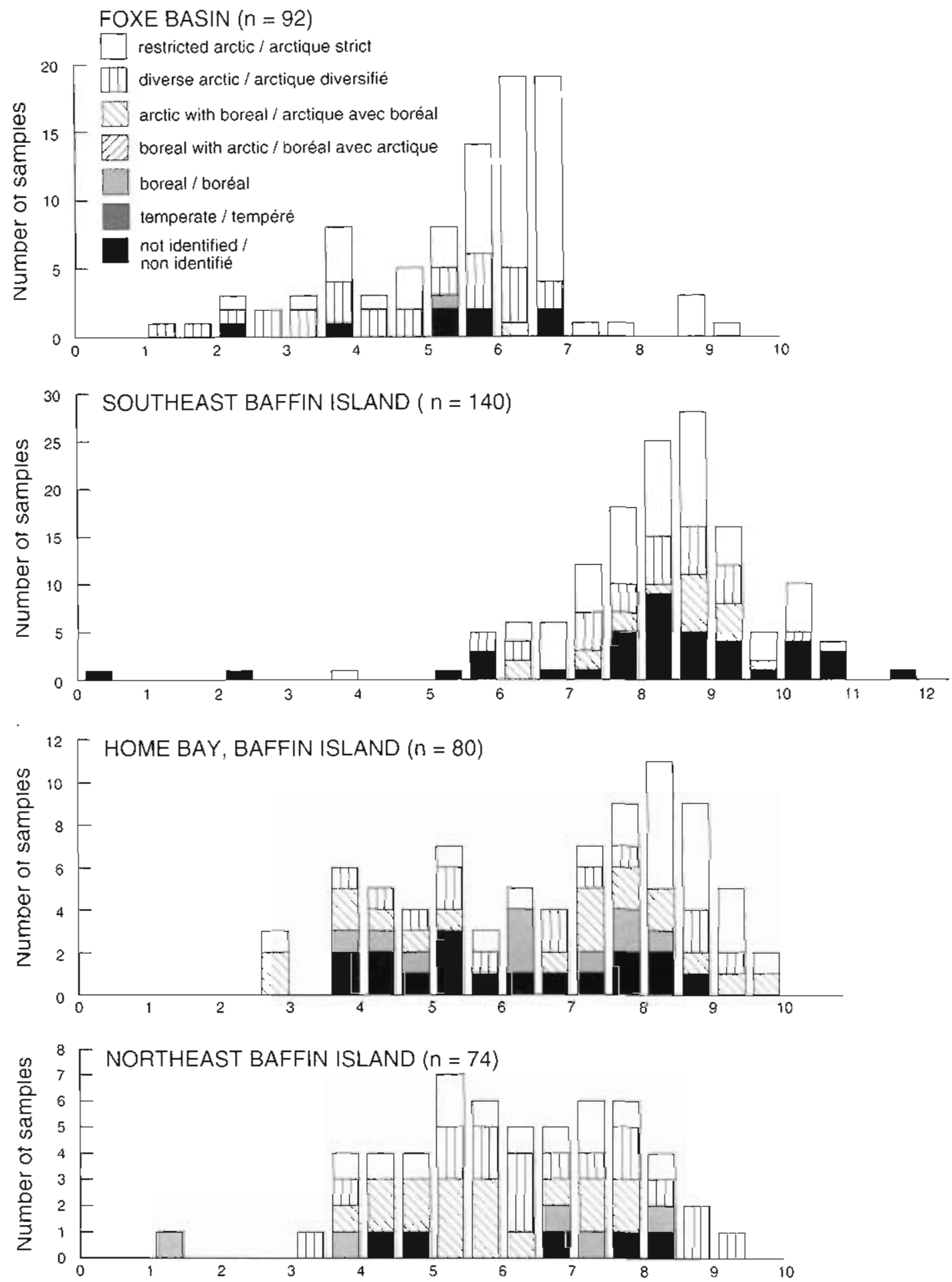

Radiocarbon years BP

FIGURES 8-11. Frequency distributions of marine moliusc assemblages in the Foxe Basin region, the southeast Battin Island region, the Home Bay region, and the northeast Baffin Island region.
Histogrammes de frëquence des assemblages de mollusques marns dans les régions du bassin de Foxe, du sud-est de l'ile de Baftin, de la baie de Home, ef du nord-est de linle de Baffin. 
considered a thermophile north of Cape Dyer (Andrews, 1972). Chlamys islandica appears in the record at $8.23 \mathrm{ka} \mathrm{BP}$, Mytilus edulis at $8.19 \mathrm{ka} \mathrm{BP}$, and Macoma balthica at $7.08 \mathrm{ka}$ $\mathrm{BP}$. The latter two are common in the interval 5-3 ka BP when Astarte montagui is also listed. A. montagui is similar to $A$. striata but has a more southerly range. Collectively these southern species seem to have been most abundant 8-7 ka $\mathrm{BP}$, with 12 records, but $M$. edulis and $M$. balthica are most common from $7-3 \mathrm{ka} \mathrm{BP}$. Hiatella arctica is not recorded in samples older than $9 \mathrm{ka}$ and is subordinate to Mya truncata throughout. The dearth of samples dating younger than $2.7 \mathrm{ka}$ $B P$ leaves the retraction of ranges to present limits undated.

\section{NORTHEAST BAFFIN ISLAND}

This region (\#8 in Fig. 2) coincides largely with Lubinsky's high arctic province IV, and although farther north, subarctic species that do not occur in Home Bay - including Astarte striata and Mytilus edulis - sporadically reappear here. The region may represent a westward extension of the relatively warm West Greenland faunal region (Lubinsky, 1980, p. 61), or the present outposts of subarctic species may be relicts of a general expansion of ranges up the Baffin coast. The outpost of $M$. eduils at Pond inlet may have been reseeded from mussels attached to whaling ships in the last century (J.T. Andrews, personal communication, 1995).

The histogram for this region (Fig. 11) has the usual profile of well-dated earlier Holocene taunas and a nearly undated later Holocene. Much of the region has experienced late Holocene submergence, which partly accounts for this. This record does not display an early dominance of the restricted arctic assemblage. Instead, diverse arctic assemblages and arctic assemblages with boreal-subarctic elements comprise the bulk of the record. The earliest recorded boreal entries, both in the same sample, are Mytilus edulis and Macoma balthica at $8.25 \mathrm{ka} \mathrm{BP}$. These two dominate occurrences of boreal taxa and jointly reach maximum percentile abundance in the interval 6-4 ka BP when each occurs in $27.3 \%$ of identified samples. $M$. balthica withdrew sometime after $4 \mathrm{ka} \mathrm{BP}$ to a limit about $1000 \mathrm{~km}$ to the south; $M$. edulis remains in isolated colonies but its main limit has retracted a comparable distance, assuming a southward rather than eastward retreat. Thus, there appears to have been greater influence of subarctic water masses or much greater solar warming of the littoral zone during the period $8.25-4 \mathrm{ka} B P$ than after.

The other recorded boreal species are Astarte striata, A. montagui, and Mya arenaria, the latter two in single samples and the last indicating a range extension of $2300 \mathrm{~km}$ at $4.85 \mathrm{ka}$ $\mathrm{BP}$ (GSC-4379). As with other extreme range extensions, the identification should be checked to guard against misidentification of $M$. pseudoarenaria.

Recent field work by Dyke (see McNeely and Jorgensen, 1993; McNeely, in press) has shown a difference between Holocene molluscs present on either side of the western boundary of this region. Mytilus edulis fossils were found at several sites along Navy Board and Milne inlets, just east of the boundary, but not along Admiralty Inlet, just west; earlier collections by B.G. Craig show the same pattern. We are confident that the maximum range extension of the boreal taxa was not beyond the mouth of Navy Board Inlet.

The dominant species in this record, in order of apparent abundance, are Hiatella arctica, Mya truncata, Macoma calcarea, Mytilus edulis, and Macoma balthica. M. calcarea reaches peak abundance (54.5\% of samples) at 6-4 ka BP as do the two boreal elements. $M$. truncata also is at peak percentile abundance then $(86.4 \%)$, but $H$. arctica declines about 6 ka BP (from $80 \%$ to $59.1 \%$ ).

\section{SOUTHERN WEST GREENLAND}

This subarctic region (\#9 in Fig. 2) is warmed by the West Greenland Current. The dated faunal record extends back to $10 \mathrm{ka} \mathrm{BP}$ with an outlier (Mya truncata) at $13.5 \mathrm{ka}$ BP. Much of the region has experienced late Holocene submergence (Kelly, 1973).

In that boreal and diverse arctic species are present at deglaciation, there is no obvious succession of postglacial environments (Fig. 12). The dominant species throughout are Mya truncata and Hiatella arctica, with the former consistently more numerous. However species diversity does change through time: 15 species are recorded for $10-8 \mathrm{ka} \mathrm{BP}, 31$ for 8-6 $\mathrm{ka}_{\text {, }}$ and 15 for $6-4 \mathrm{ka}$. The increased diversity at $8-6 \mathrm{ka}$ is due mainly to addition of boreal elements, with 13 such species at that time compared to only 3 previously. The first appearances of boreal animals in the record are: Chlamys islandica at $9.4 \mathrm{ka}$, Mytihus edulis at $9.07 \mathrm{ka}$, Balanus hameri at $8.54 \mathrm{ka}$, Astarte striata at $7.98 \mathrm{ka}$, Buccinum undatum at $7.73 \mathrm{ka}$, Lora nobilis at $7.73 \mathrm{ka}$, Lima subauriculata at $7.55 \mathrm{ka}$, Crenella decussata at $7.34 \mathrm{ka}$, Epitonium sp. at $7.22 \mathrm{ka}$, Macoma balthica at $6.84 \mathrm{ka}$, Littorina saxatilis at $6.84 \mathrm{ka}$, and Zirphaea crispata at $5.19 \mathrm{ka}$. Funder and Weidick (1991) list additional taxa, now extinct in Greenland, that occupied the area $8.4-4.9 \mathrm{ka} \mathrm{BP}$. Funder and Weidick (1991) pointed out that the extinct species occurred along a small part of the West Greenland coast where today the cold polar water is deflected westward across Davis Strait, leaving water from the Irminger Current to warm the coastal zone. They thus infer that this division of currents has been in place since at least $8.4 \mathrm{ka} \mathrm{BP}$.

\section{EAST GREENLAND}

The faunal record of East Greenland (\#10 in Fig. 2; Fig. 13) differs greatly from that of West Greenland. The East Greenland record has an arctic aspect in that it is dominated by the restricted arctic assemblage from deglaciation until $6.5 \mathrm{ka} \mathrm{BP}$ and species diversity is markedly reduced. The interval t0.3$8 \mathrm{ka}$ has 10 species; 8-6 ka, 12 species; and 6-4 ka, 9 species. Mya truncata and Hiatella arctica are exceedingly abundant, the former somewhat more than the latter. Both decline in relative abundance through time, from $90.8 \%$ to $62.5 \%$ and from $70.8 \%$ to $50 \%$, respectively. At the same time Macoma calcarea increases from $13.8 \%$ to $62.5 \%$ of records.

Species regarded here as thermophiles represent range extensions into the area. Their order of appearance in the record is: Astarte elliptica at $9.01 \mathrm{ka}$, Nucula tenuis and $8.67 \mathrm{ka}$, Chlamys islandica at $8.58 \mathrm{ka}$, Mytilus edulis at $7.87 \mathrm{ka}$, and Mya arenaria at $5.58 \mathrm{ka} \mathrm{BP}$. Only $M$. edulis is 

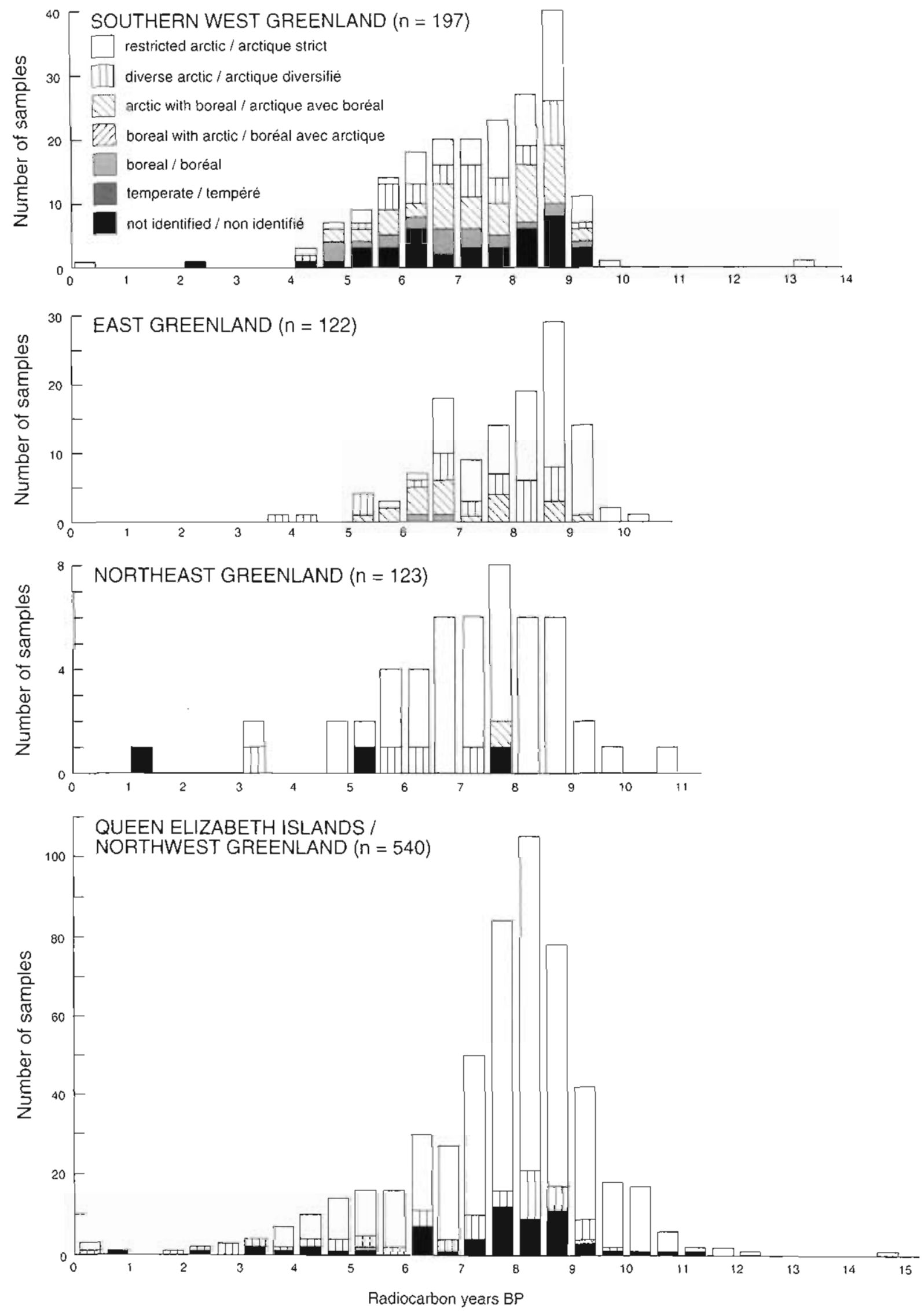

FIGURES 12-15. Frequency distributions of marine mollusc assemblages in the southwest Greenland region, the east Greenland region, the northeast Greentand region, and the Queen Elizabeth Islands / northwest Greenland region.

Histogrammes de fréquence des assemblages de mollusques marins du sud-ouest du Groenland, de l'est du Groenland, du nord-est du Groenland, ainsi que de l'archipel de la Reine Elizabeth et du nordouest du Groenland. 
common; it occurs in about $25 \%$ of samples from 8 to $4 \mathrm{ka}$ BP. Hjort and Funder (1974) suggested that $C$. islandica and $M$. edulis expanded into this area from Spitsbergen, rather than from south Greenland, and that this could have been caused by a shift in the balance between the cold East Greenland and the warm West Spitsbergen current.

\section{NORTHEAST GREENLAND}

The faunal record for northeast Greenland (\#11 in Fig. 2; Fig. 14) is further impoverished with respect to central East Greenland. All but 5 samples with identified taxa fall in the restricted arctic assemblage. Only 5 species are listed from this region, all pelecypods. Bennike (1987) reports 10 species of subfossil pelecypods from the region but does not provide radiocarbon dates. Before $8 \mathrm{ka} \mathrm{BP}$. Hiatella arctica is dominant; thereafter it and Mya truncata are equally abundant. The more diverse assemblage results from the additional presence of Astarte borealis. Astarte elliptica is the single boreal-subarctic species appearing at $7.73 \mathrm{ka} \mathrm{BP}(W$ 1088). It has a low arctic-boreal range today extending up the West Greenland coast to the head of Baffin Bay and nothward to Cumberland Sound in the Canadian Arctic.

\section{QUEEN ELIZABETH ISLANDS - NW GREENLAND}

The faunal record of this high arctic region (\#12 in Fig. 2; Fig. 15), which corresponds to Lubinsky's "endemic province of northern Canadian Arctic Archipelago", resembles that of northeast Greenland. The record is dominated by restricted arctic assemblages with diverse arctic assemblages making up most of the rest. The oldest date is on Hiatella arctica at $14.88 \mathrm{ka} \mathrm{BP}$ (TO-475) from northern Ellesmere Island (Evans, 1990). This important sample demonstrates that at least this species survived the last glacial maximum along the shores of the Arctic Ocean. Thus, postglacial recolonization by molluscs did not necessarily occur in the form of a front advancing from the south. Since completion of the database, a second record of this species from the region, dating $14.6 \mathrm{ka} \mathrm{BP}$, has been published (Hodgson et al., 1994), but further dating has shown this to be a blended age.

Boreal elements are recorded in only two samples. Mytilus edulis and Chlamys islandica occur in a sample dated $9.15 \mathrm{ka}$ $\mathrm{BP}(\mathrm{K}-4781)$ in the Thule area of northwest Greenland. This records early penetration of these thermophiles to the head of Baffin Bay and indicates that the West Greenland Current was functioning by then. The only record of a southern species in the Queen Elizabeth Islands is that of $C$. islandica on east-central Ellesmere Island at $5.35 \mathrm{ka} \mathrm{BP} \mathrm{(TO-390).} \mathrm{This}$ site is in the small part of the Queen Elizabeth Islands influenced by the West Greenland Current.

The faunal records illustrated by Figures 14 and 15 represent high arctic marine environments that have never warmed enough to allow a wider variety of molluscs to survive than are there today. Under these restricted conditions, a dramatic postglacial succession would not be expected. Yet a subtle succession seems to have occurred. Before $10 \mathrm{ka} \mathrm{BP}$ only 4 species are recorded. This increases 1017 species for the period $10-8 \mathrm{ka}$. The most common additions to the fauna after $10 \mathrm{ka}$ are Astarte sp., A. borealis, and Macoma calcarea.
Astarte becomes the dominant taxon in the record for the last $4 \mathrm{ka}(55.6 \%$ of samples, $n=18$ ). But unfortunately, this part of the record is too little dated to determine firmly whether an important shift in faunal composition occurred. Hiatella arctica and Mya truncata were strongly dominant, in that order, before $4 \mathrm{ka} \mathrm{BP}$. Although $H$. arctica and $M$. truncata today range southward into the subarctic, we suggest that the closest analogue of fossil assemblages strongly dominated by - or limited to - these species in present boreal to low arctic areas is the postglacial records of the Queen Elizabeth Islands and northeast Greenland.

\section{CENTRAL ARCTIC ISLANDS}

The central arctic islands region coincides with Lubinsky's central shallow-water province of the high arctic. It lies south of and contiguous with the Queen Elizabeth Islands ( $\$ 13$ in Fig. 2). Although not as intensively dated, its faunal record differs somewhat from that of the northernmost region in its greater diversity, i.e. a smaller proportion reporting Hiatella arctica and Mya truncata only (Fig. 16). The central region exhibits a similar diversification through time. Comparing the $11-8 \mathrm{ka}$ BP interval with the post-6 ka BP interval, $H$. arctica declines from presence in $84 \%$ to $45 \%$ of samples; $M$. truncata declines from $68.9 \%$ to $45 \%$; Astarte borealis increases from $8.5 \%$ to $60 \%$; Serripes groenlandicus from $5.7 \%$ to $30 \%$; and Macoma calcarea from $8.5 \%$ to $25 \%$. As tarther north, this middle Holocene diversification is not sufficiently well dated at present to be adequately characterized.

Three samples reportedly contain boreal species. Mya arenaria is reported from northeast Victoria Island at $8.37 \mathrm{ka}$ BP (GSC-4650) and Macoma balthica from southern Victoria Island at $8.12 \mathrm{ka} \mathrm{BP}$ (GSC-4242). A single record of Mytilus edulis trom the northern mainland is dated $7.16 \mathrm{ka} \mathrm{BP}$ (I(GSC)-212). Mytilus extends nearly to the southwestern boundary of the region today from the Beaufort Sea (see below) and this sample may represent a brief extension of that range. Neither of the other two occur in or near the region. In the Pacific, $M$. arenaria ranges north to the Aleutian Islands and $M$. balthica into the Bering Sea. The latter is thus poised to enter the Arctic Ocean through Bering Strait and is identified in several samples from the region discussed next.

The data from this region along with that from Foxe Basin and northeast Baffin Island do not support the conclusion of Andrews (1972) that $M$. edulis and $M$. balthica spread westward across the entire mainland coast during the period 8$2.5 \mathrm{ka} \mathrm{BP}$. If such extensions occurred, they were very briet and have not yet been recorded. Apart from diversification following deglaciation, the regional faunal record indicates unwavering high arctic conditions.

\section{WESTERN ARCTIC MAINLAND - SOUTHWESTERN ISLANDS}

This region (\#14 in Fig. 2) corresponds to Lubinsky's southwestern Canadian Archipelago province and differs from the rest of her high arctic faunistic zone in the presence here of Pacific species and subarctic elements, especially Mytilus edulis. The western third of the region has been submerging throughout the Late Wisconsinan and Holocene but the east- 

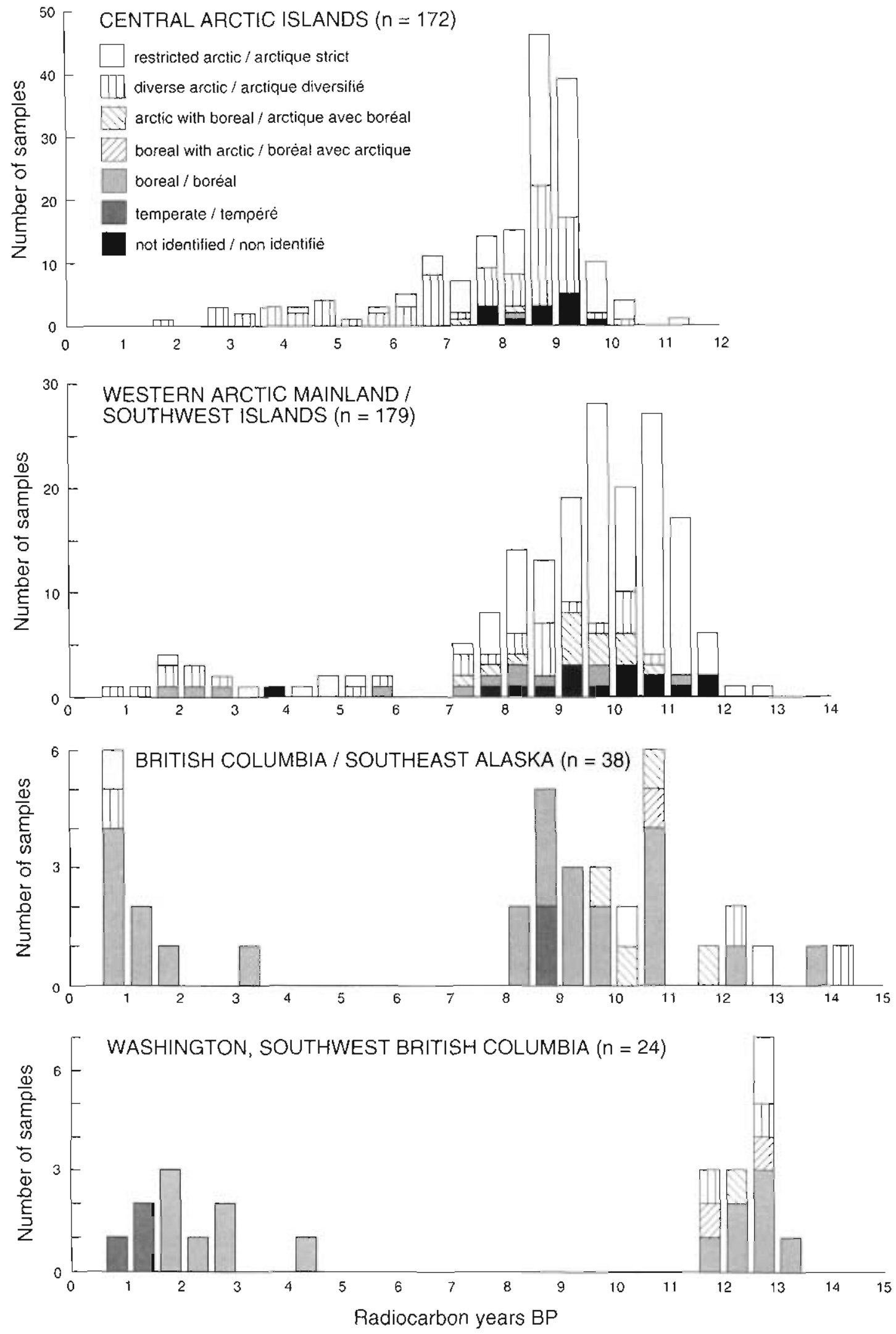

FIGURES 16-19. Frequency distributions of marine mollusc assemblages in the central Arctic Islands region, the western arctic mainland / southwestern arctic islands region, the British Columbia/southeast Alaska region, and the Washington / southwest British Columbia region.
Histogrammes de fréquence des assemblages de mollusques marins dans les régions des illes centrales de l'Arctique, de l'Arctique de l'ouest continental et des iles du sud-ouest de l'Arctique, de la Colombie-Britannique et du sud-est de l'Alaska, ainsi que de l'état de Washington et du sud-ouest de la Colombie-Britannique. 
ern part has been emerging since deglaciation (Dyke and Dredge, 1989).

There are two interesting features of the this faunal record. First, the greater importance of boreal elements than in neighbouring records is clear (Fig. 17) and is expected from the present fauna. Second, a strong shift in relative abundances of Hiatella arctica and Mya truncata occurred at 10-10.5 ka BP. This was not anticipated as a feature of this faunal record and has not been previously documented; it may be generally significant for the high arctic paleoenvironmental record. $H$. arctica occurs in $89.6 \%$ of samples $(n=67)$ dated $>10 \mathrm{ka}$ BP (Portiandia arctica accounts for most of the rest); $M$. truncata occurs in $3 \%$, in 2 samples dated $11.8 \mathrm{ka}$ and $10.2 \mathrm{ka}$ BP. This severe imbalance of the proportions of these two species is unique to this region and to this age group. The imbalance disappears about $10.3 \mathrm{ka} \mathrm{BP}$ (10.2-10.5 ka); in the $10-8 \mathrm{ka}$ age group $H$. arctica occurs in $67.6 \%$ of samples $(n=68)$ and $M$. truncata in $36.8 \%$. We suggest below that the shift from imbalanced to balanced proportions coincides with submergence of Bering Strait, with influx of Pacific surface water to the Arctic Ocean, and with the entry of bowhead whales into the High Arctic (Dyke and Morris, 1989; Dyke et al, in review). These correlations suggest that $H$. arctica colonized the Canadian Arctic Aschipelago before $10.5 \mathrm{ka} \mathrm{BP}$ by dispersing from the Arctic Ocean or from the Allantic via North Greenland very early in deglaciation. Portlandia arctica was also a very early arrival or survivor in the Arctic Ocean. $M$. truncata, in contrast, may have been eliminated from the Arctic Ocean by the last glacial maximum and unable to access the western arctic mainland until opening of Bering Strait.

This dramatic ecostratigraphic change in the record of the western Arctic stands out simply because of the large number of samples that date older than $10 \mathrm{ka}$ BP. The paucity of dates in that range in the neighbouring regions to the east and north precludes as clear a recognition of this event. However, available data indicate that $M$. truncata was absent or exceedingly sparse there too before $10.5 \mathrm{ka} \mathrm{BP}$. Its earliest records from the central arctic islands region are samples dated 10.1 and $10.07 \mathrm{ka}$, whereas the record of Hiatella arctica there extends back to $11.01 \mathrm{ka} \mathrm{BP.} \mathrm{M.} \mathrm{truncata} \mathrm{is} \mathrm{dated} \mathrm{at} 12.2 \mathrm{ka} \mathrm{BP}$ on Saunders Island at the head of Baffin Bay, but this site was accessible directly from the Atlantic and the record does not imply presence of the species in the Arctic Ocean. Its only record in the entire Queen Elizabeth Islands before $10 \mathrm{ka} \mathrm{BP}$ is in a sample from Hot Weather Creek, west-central Ellesmere Island. $H$. arctica in that sample dated $10.6 \mathrm{ka} \mathrm{BP}$. There are 25 records of $H$. arctica in the Queen Elizabeth Islands with dates $>9.8 \mathrm{ka} \mathrm{BP}$ as compared to the one $M$. truncata.

The earliest recorded entry of a boreal species to the western arctic mainland region (Fig. 17) is a sample reporting Macoma balthica dating 11.4 ka BP (GSC-3840). If correctly identified, it indicates either migration into the region along the Eurasian coast from the Barents Sea or incursion of $\mathrm{Pa}$ cific fauna into the Arctic Ocean by that time. In either case it surprisingly precedes $M$. truncata. Entry from the Pacific at $11.4 \mathrm{ka} \mathrm{BP}$ is problematic: it requires submergence of Bering Strait, with a sill depth of about $50 \mathrm{~m}$, at a time when global eustatic sea level was much lower (about $-75 \mathrm{~m}$; Fairbanks, 1989; Tushingham and Peltier, 1991). Migration from Barents Sea is thus more feasible. The significant implications for water temperatures along the Eurasian coastline require that this record be confirmed.

Subsequent boreal species records are about $1 \mathrm{ka}$ younger: $M$. balthica at $10.5 \mathrm{ka}(\mathrm{I}(\mathrm{GSC})-25)$ and Mytilus edulis at $10.35 \mathrm{ka} \mathrm{BP}$ (UQ-722). These are essentially coincident with the arrival of $M$. truncata. The only other reported boreal species in this record is Mya arenaria, which is listed in five samples (GSC-4747, $-4537,-4608,-4579$, and AECV-948c), the oldest of which dates $9.64 \mathrm{ka} \mathrm{BP}$. This represents a great range extension of the Pacific population which now ranges north to the Aleutian Islands. As with all high arctic records of this species, identifications should be confirmed.

This regional record lists only 13 species of pelecypods and cirripeds. None of the Pacific forms that are unique to this part of the Canadian High Arctic yet have a fossil record. The common arctic mollusc Serripes groenlandicus occurs in the area but is not reported in any fossil collection and Clinocardium ciliatum is poorly represented. The absence of Chlamys islandica is interesting because on the Atlantic side it extended its range in company with $M$. edulis, ahead of $M$. balthica, and much farther than $M$. arenaria. In the Pacific today it ranges north to Alaska. $M$. edulis still occupies the region and is the third most common species of record. It occurs in $17.6 \%$ of samples for the interval $10-8 \mathrm{ka}, 8.3 \%$ for 8-6 ka, and $15.6 \%$ for <6 ka BP. It exceeds Macoma calcarea, the only other commonly reported pelecypod, in abundance and far exceeds Astarte borealis, which appears to be rare here. $M$. balthica has withdrawn to the Bering Sea; its youngest record is $2.51 \mathrm{ka} \mathrm{BP}$ (GSC-158).

\section{BRITISH COLUMBIA - SE ALASKA}

The entire coast from the Mackenzie Delta to southern Alaska lacks a fossil mollusc record for the last $18 \mathrm{ka}$. This coastline has been submerging throughout that time and its faunal record is not available. Some of the species that survived during the last glacial cycle south of Beringia are known from the list of early arrivals in the western Arctic discussed above.

Even the emergent, glaciated coastline of the Pacific is poorly sampled. We have found only 37 dated samples of identified marine shells for the British Columbia - SE Alaska region (\#15 in Fig. 2; Fig. 18). About as many shell dates have no taxa reported. The database, however, points to a record of a different type than any discussed above. Although some arctic-subarctic molluscs are reported, boreal taxa dominate even at deglaciation, and there is some suggestion of a faunal succession. Before $12 \mathrm{ka} \mathrm{BP}$ there are records of only 4 species of pelecypods and Balanus sp. in 7 samples. These include the panarctic Mya truncata and Macoma calcarea but also two animals that have their northern limits in the area today - Macoma nasuta and Macoma liparia. The list for $12-$ 10 ka BP (12 samples) includes 14 species of pelecypods and 3 gastropods, all of which occur in the region today. Only 6 species are recorded for the 13 samples dated $10-8 \mathrm{ka}$ BP but 5 of these are additions to the previous fauna. One, 
Protothaca tenerrima from Haines Creek at 53⒌' $N$ dating 8.85 ka BP (GSC-2534), may record a range extension from its present limit around Vancouver.

\section{SW BRITISH COLUMBIA - WASHINGTON}

This region (\#16 in Fig. 2) is the counterpart of the Gulf of Maine in that the Cordilleran Ice Sheet advanced here into the warmest water at the last glacial maximum. Although mollusc assemblages here are not extensively dated (Fig. 19; no identifications found for 57 of 88 samples), the record differs from that of the Gulf of Maine in that arctic molluscs were not dominant during early stages of deglaciation. Considering the small data set, there is a diverse array of mostly boreal taxa - 22 in 16 samples ( 6 identified to genera only). The least thermophilous taxa for the interval $>11 \mathrm{ka} \mathrm{BP}$ extend to Puget Sound today. On this evidence, the glacial maximum and early deglacial seas may not have been much colder than present. Hence, the southwestern and perhaps much of the western margin (Fig. 18) of the Cordilleran Ice Sheet terminated in warmer water than did the Laurentide lce Sheet at its southeast extremity. In this light, it seems improbable that the periglacial zone of the Cordilleran Ice Sheet at the last glacial maximum served as a refugium of many arctic marine invertebrates. Those that retreated to the Pacific likely survived along the Beringian coast.

\section{PALEOGEOGRAPHY}

In this section, we examine the mollusc data in $1 \mathrm{ka}$ steps in order to map shifting paleofaunistic zones as they relate 10 the shrinking ice sheets. We infer general surface water mass characteristics from mollusc assemblages and postulate causal mechanisms for changes. We assume that ocean circulation at the last glacial maximum involved a Gulf Stream transporting warm water northward and other currents transporting cold water southward in the North Atlantic. We also assume existence of a proto-Beaufort Gyre. This is supported by wind directions along the Beaufort coast during the glacial maximum (Carter, 1981), but the assumption does not constrain our data interpretations. We also consider constraints as well as supporting and conflicting interpretations arising from other marine paleoenvironmental data sets. However, it is not our intention to synthesize these latter data. Because there are no dated molluscs for the height of the last glacial maximum (18 ka BP) and sparse data immediately thereafter, we start the map series at 14 ka BP. Each map displays data for the preceding $1 \mathrm{ka}$ interval but we interpret conditions for the end of each interval.

Outlines of ice sheets and shorelines, are simplified and modified from Dyke and Prest (1987) with the addition of Cordilleran Ice Sheet margins for 13,12 , and $11 \mathrm{ka} \mathrm{BP}$ from Ryder (unpublished contract report to GSC, 1993). There is a growing need to generally update the deglaciation history of Dyke and Prest (1987). However, this is well beyond the scope of this paper as it involves more than simply incorporating suggested revisions. The more substantive proposed revisions indicate later ice retreat than proposed by Dyke and Prest (1987). Those proposed by Macpherson (1988; personal communication, 1995) for the Avalon Peninsula of Newfound- land and by Richard et al. (in review) for the Gaspé Peninsula of Québec are incorporated in the paleogeographic maps herein. Macpherson (1988) argued that the Avalon Peninsula of Newtoundland remained ice covered until about $10 \mathrm{ka} B P$ based on basal lake sediment ages, 3 ka later than proposed by Dyke and Prest. Fichard of al. (in review) showed by AMS dating of macrofossils that previous conventional radiocarbon dates from the plateau of Gaspé Peninsula are too old and that deglaciation finally occurred after $10 \mathrm{ka}$ BP rather than about 12 ka BP. Payette (1993) and Gray et al. (1993) proposed that final deglaciation of the Ungava region of Québec occurred 5.5-5 ka BP, 1 ka later than the date suggested by Dyke and Prest (1987). The younger deglaciation proposal for that area is based on a few basal peat and gyttja dates that Dyke and Prest (1987) regarded as not closely constraining the dates of deglaciation and on a peculiarity in the present distribution of Larix. Similarly Lemmen ef al. (1994b) took the sparse set of basal organic dates from the District of Mackenzie to more closely date deglaciation than did Dyke and Prest and thus decreased the date of deglaciation on average by about $0.5 \mathrm{ka}$.

\section{MOLLUSCAN ZONES AT 14 ka BP}

Sparsity of data makes any reconstruction of faunistic zones at this time tentative. Data from the Gulf of Alaska indicate a diverse arctic assemblage just before $14 \mathrm{ka} \mathrm{BP}$. As discussed above, the waters at the southwestern margin of the Cordilieran lce Sheet had mollusc assemblages warmer than those in the Gulf of Maine - Gulf of St. Lawrence region. Hence, we show a broad Pacific boreal zone with subarctic conditions only in the periglacial fringe where meltwater would have been influential. The Pacific boreal zone today extends south to $34^{\circ} \mathrm{N}$; therefore, the area labelled "undefined" on Figure 20 was probably entirely boreal.

Boreal taxa in the Gulf of Maine and, at least as a minor element, on the Scotian Shelf indicate that a north-flowing Gulf Stream mitigated the effect of the melting ice sheet on the adjacent ocean (Fig. 20). However, the boreal zone may have been narrow for most of the southeastern periglacial region supported arctic taxa. Water temperatures would have been depressed by the large meltwater flow and by strong northwesterly winds (COHMAP Members, 1988; Mudie and McCarthy, 1994) and the effect of the Gulf Stream would have been further limited by its sharp eastward deflection by the emergent Georges Bank. The modem arctic faunai zone lacks vertical zonation due to insufficient seasonal heating. This was unlikely in the Gulf of St. Lawrence and on the shallow Scotian Shelf at $14 \mathrm{ka} \mathrm{BP}$, where conditions were probably subarctic. However, summer meltwater flow through the inner gulf at $14 \mathrm{ka} \mathrm{BP}$ was enough to freshen the entire water column (deep water salinity <20 per mil; Rodrigues et al., 1993).

Rahman and de Vernal (1994) concluded that the sea off eastern Newfoundland was cold and (or) seasonally ice covered between 23 and $13 \mathrm{ka}$ BP on the basis of the nannofossil record in a welf-dated sediment core. The Labrador Current at that time may have been a direct continuation of the East Greenland Current and neither was influenced by the Irminger Current. Therefore, arctic water probably occupied the entire 
east coast to southeastern Newfoundland. Between 14 and $13 \mathrm{ka} \mathrm{BP}$ the Labrador Current was influenced by exceptional ice berg production that produced a distinct layer of ice-rafted detritus, a so-called Heinrich layer (event), across much of the North Atlantic (Dowdeswell et al, 1995). Andrews et al. (1994) suggested that this berg calving was accompanied by major meltwater discharge from Hudson Strait and by rapid retreat of the eastern Laurentide Ice Shoet. The 14-13 ka BP Heinrich layer $(\mathrm{H} 1)$ is also distinguished by a peak abundance of reworked pre-Quaternary microfossils of European provenance, which indicates that the Fennoscandian and (or) British ice sheets also released bursts of ice bergs at the same time, presumably in response to a common controlling mechanism (Rahman, 1995). The extensive oceanic ice front and ice berg production at $14 \mathrm{ka}$ BP would have chilled surface water and retarded seasonal warming.

The sample of Hiatella arctica from the Arctic Ocean shore (Fig. 20) illustrates that this mollusc was able to survive glacial maximum conditions in the most polar sites. Its dominance of faunas south to the Bay of Fundy demonstrates an enormous range in shallow water at $14 \mathrm{ka} \mathrm{BP}$. It must be one of the most robust animals in terms of adaptation to environmental change. The large latitudinal span of western North Atlantic arctic taxa is in striking contrast to that of its boreal taxa as is the span of the Pacific boreal zone. Habitats of obligate shallow-water boreal species at $18 \mathrm{ka}$ BP in the Atlantic, when the Laurentide Ice Sheet extended to Long Island. must have been even more restricted than at $14 \mathrm{ka}$.

\section{MOLLUSCAN ZONES AT $13 \mathrm{ka} \mathrm{BP}$}

Boreal molluscs extended north of Vancouver Island by $13 \mathrm{ka} \mathrm{BP}$. We suggest an expanding marine boreal zone and shrinking subarctic zone there but the database is inadequate to define boundaries properly (Fig. 21). The Gulf of Maine Gulf of St. Lawrence region, in contrast, is richly dated. Restricted arctic and diverse arctic assemblages dominate the regional fauna ( $74 \%$ of samples), particularly in the Gulf of St. Lawrence. However, a few boreal elements are present, possibly indicating vertical faunal zonation. The fauna grades to mostly boreal southward and the boreal zone seems to have expanded northward since $14 \mathrm{ka} \mathrm{BP}$. This could be due to a decreased meltwater flux through the Gulf of Maine by $13 \mathrm{ka} \mathrm{BP}$. The fauna in the more ice-proximal Bay of Fundy retained an arctic aspect. The single arctic site dated $>13 \mathrm{ka}$ $\mathrm{BP}$ (southwest Greenland) records the minimum northward extension of Mya truncata. Foraminiferal and diatom records from the continental shelt off Hudson Strait indicate moderate biological productivity and water seasonally cleared of sea ice by $13 \mathrm{ka} \mathrm{BP}$ (Andrews el al., 1990).

\section{MOLLUSCAN ZONES AT $12 \mathrm{ka} \mathrm{BP}$}

Pacific boreal fauna extended north at least to Queen Charlotte Sound and was common in fairly ice-proximal sites in southwestern British Columbia (Fig. 22). The Cordilleran ice margin had largely retreated from the outer coast so that meltwater influence on the nearshore zone was less. Subarctic conditions may have persisted along the Gulf of Alaska, but lack of identified taxa among the four dated samples from the region leaves this uncertain.
The Gulf of Maine records mainly boreal assemblages, boreal assemblages with arctic elements, and arctic dominated assemblages with boreal elements during the period 12.9-12 ka BP (Fig. 22). Arctic influence diminished until by $12 \mathrm{ka}$ BP boreal conditions apparently were established throughout the gulf. Boreal faunas also extended their range, diversity, and dominance in the Gulf of St. Lawrence to the point that the ice-distal part was boreal by $12 \mathrm{ka} \mathrm{BP}$. Subarctic conditions continued to prevail along the north shore where the Laurentide margin approximated the present coastline. This zone remained cold not only because of its ice-proximal setting but also because the Strait of Belle Isle had opened: the Coriolis effect diverts a branch of the Labrador Curreni through the strait and along the north shore. The oldest dates on marine moluscs from the Champlain Sea exceed $12 \mathrm{ka}$ $\mathrm{BP}$ (as much as $12.8 \mathrm{ka}$ ) and are plotted here incongruously in glacial Lake Iroquois (Lake St. Lawrence of Rodrigues and Vilks, 1994) and within the ice margin; these dates are considered to be 500-1000 years too old because of the "old water" (meltwater) effect in the Champlain Sea (Anderson, 1987). The samples illustrate, however, that even the earliest invaders here included boreal taxa.

In the Arctic, Portlandia arctica appears in the record on Victoria Island. Arctic Ocean conditions at this time were likely little different from those at $18 \mathrm{ka}$ BP. Therefore, $P$. arctica probably survived through the last glacial maximum along with Hiatella arctica. Both $H$. arctica and Mya truncata extended to the head of Baffin Bay by $12 \mathrm{ka}$ BP. Distal glaciomarine conditions are indicated by benthic foraminiferal assemblages along the Baffin Shelf by $12 \mathrm{ka} \mathrm{BP}$, though dating of the sediment cores is insecure (Osterman and Nelson, 1989). Williams (1990) recognized diatom productivity in one of seven cores from western Baffin Bay, suggesting seasonal open water, starting about $12.5 \mathrm{ka} \mathrm{BP}$ but with a brief barren interval at $12 \mathrm{ka} \mathrm{BP}$.

\section{MOLLUSCAN ZONES AT $11 \mathrm{ka} \mathrm{BP}$}

There are only three classified marine mollusc samples from the Pacific for the interval $11.99-11 \mathrm{ka} B P$. The Cordilleran lce Sheet and hence the periglacial subarctic zone had all but disappeared by $11 \mathrm{ka}$ BP. Reconstructions for $11 \mathrm{ka} \mathrm{BP}$ and younger in the Pacific are depicted as shown in Figure 23 - boreal conditions extending to the Aleutian Islands.

Abundantly dated faunas from the early phase of the Champlain Sea do not indicate a dominance of arctic assemblages in spite of its periglacial setting and strong meltwater influence. Boreal taxa, notably Macoma balthica, are strongly represented along with Hiatella arctica and Portlandia arctica. $M$. balthica requires summer water temperatures of at least $10^{\circ} \mathrm{C}$ for survival of its pelagic larvae (Lammens, 1967). The distribution of faunal associations in the Champlain Sea appears to have been controlled mainly by salinity and grainsize of the bottom (Rodrigues and Richard, 1986). The sea was salinity stratified throughout its existence (Rodrigues, $1987)$. $P$. arctica here is associated with high-salinity waters, whereas elsewhere it is most commonly associated with meltwater-diluted, ice-proximal deltaic enviromments. It does occur 


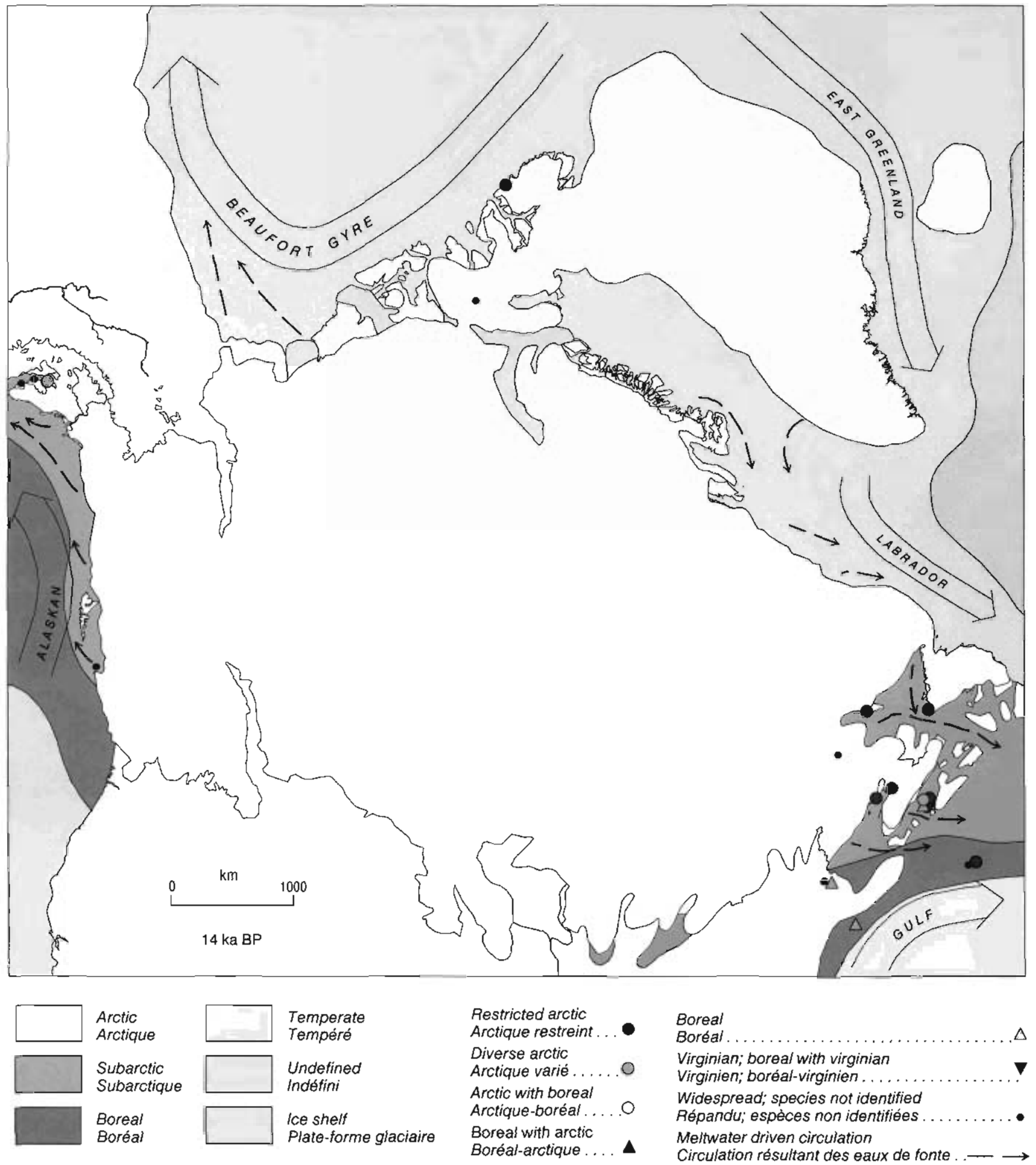




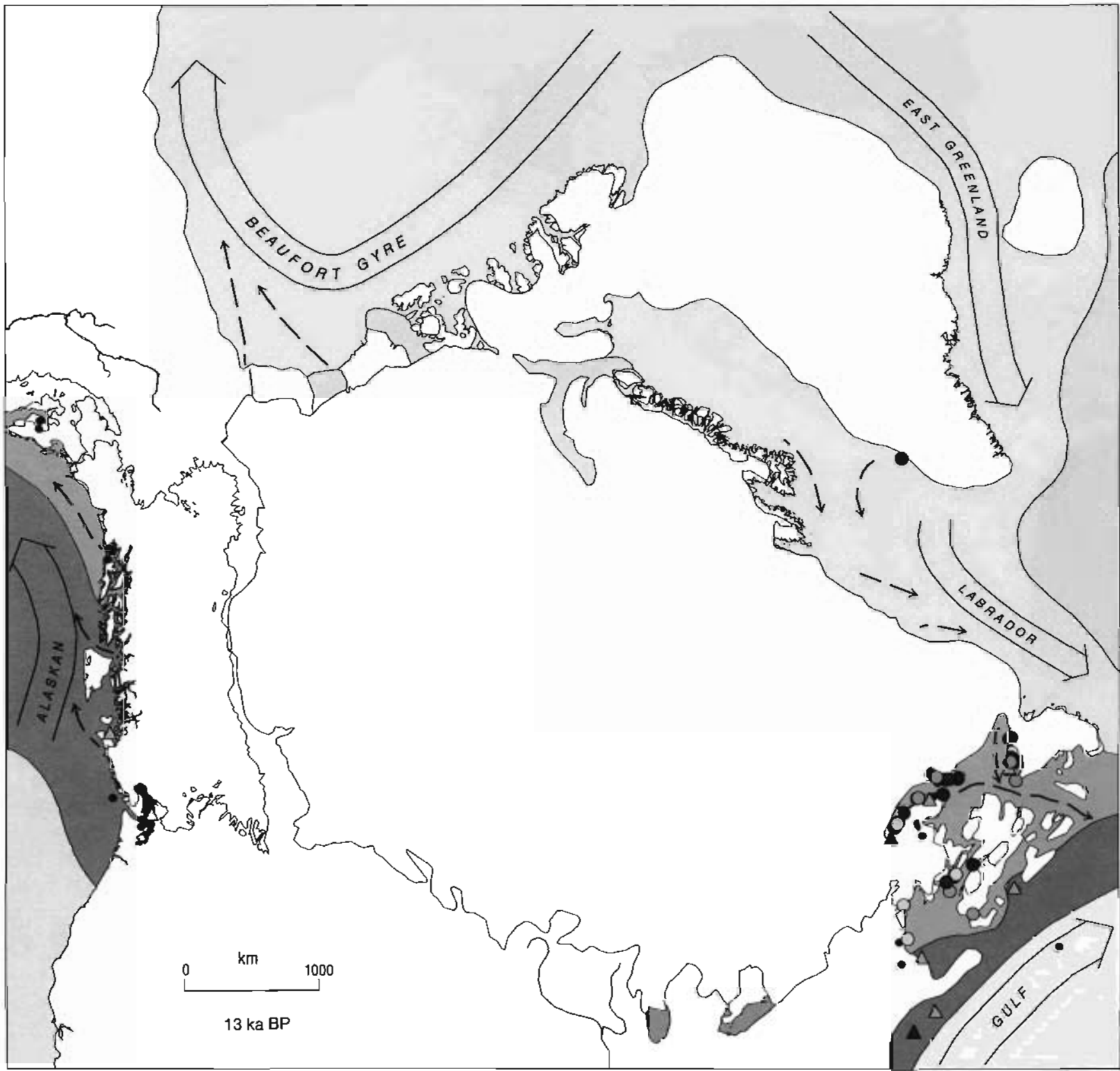

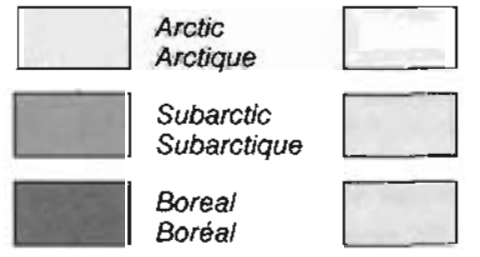

Temperate

Tempéré

Undefined Indéfini

ice shelf

Plate-forme glaciaire

\begin{abstract}
Restricted arctic Arctique restreint.

Diverse arctic Arctique varié . . . . . .

Arctic with boreal Arctique-boréal . . . . . O

Boreal with arctic

Boréal-arctique.
\end{abstract}

Boreal

Boréal ..................

Virginian; boreal with virginian

Virginien; boreal-virginien.

Widespread; species not identified

Repandu; espèces non identifiées.

Metwater driven circulation

Circulation résultant des eaux de fonte . .- $\rightarrow$
FIGURE 21. Molluscan faunistic zones at $13 \mathrm{ka}$ BP. Plotted samples date 13-13.99 ka BP.
Zones fauniques des mollusques à $13 \mathrm{ka} \mathrm{BP}$. Les âges des échantillons sont répartis de 13-13,99 ka BP. 


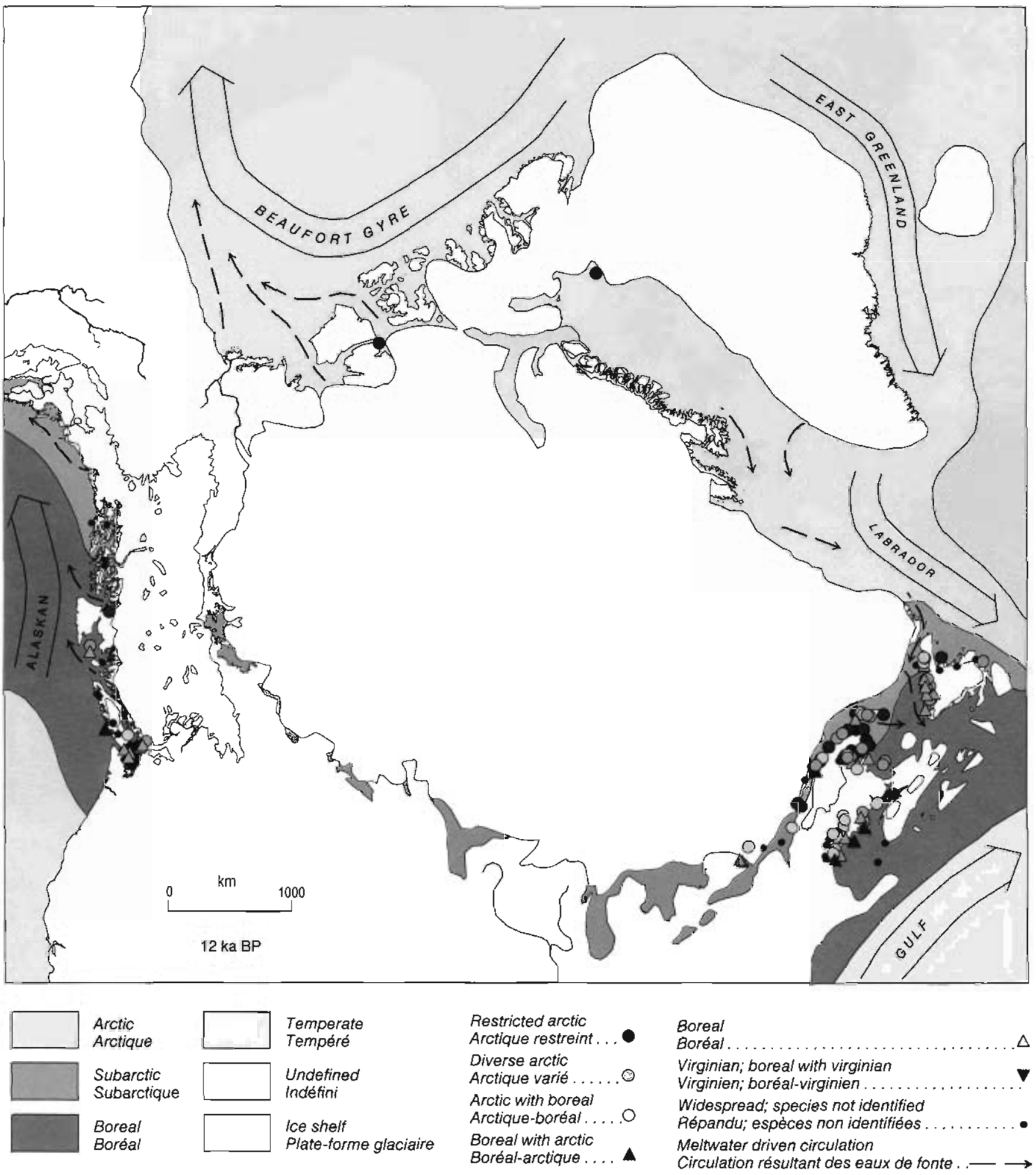

FIGURE 22. Molfuscan faunistic zones at $12 \mathrm{ka} \mathrm{BP.} \mathrm{Plotted}$ samples date 12-12.99 ka BP.
Zones fauniques des mollusques a $12 \mathrm{ka} B P$. Les ages des echantillons sont repartis de 12-12,99 ka BP. 


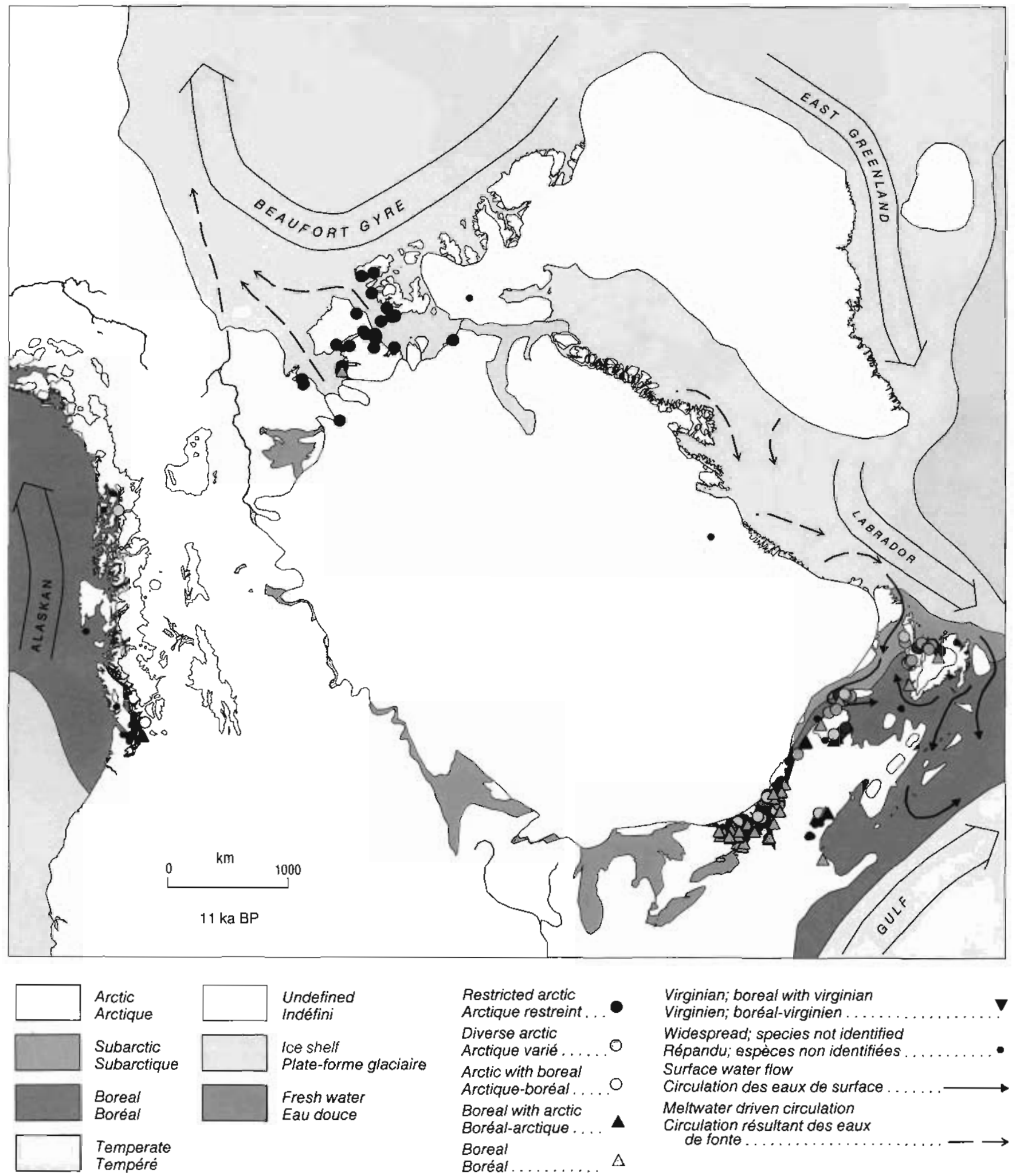

FIGURE 23. Molluscan faunistic zones at $11 \mathrm{ka}$ BP. Plotted samples date 11-11.99 ka BP.

Zones tauniques des mollusques à $11 \mathrm{ka} B P$. Les âges des echantillons sont répartis de 11-11,99 ka BP. 


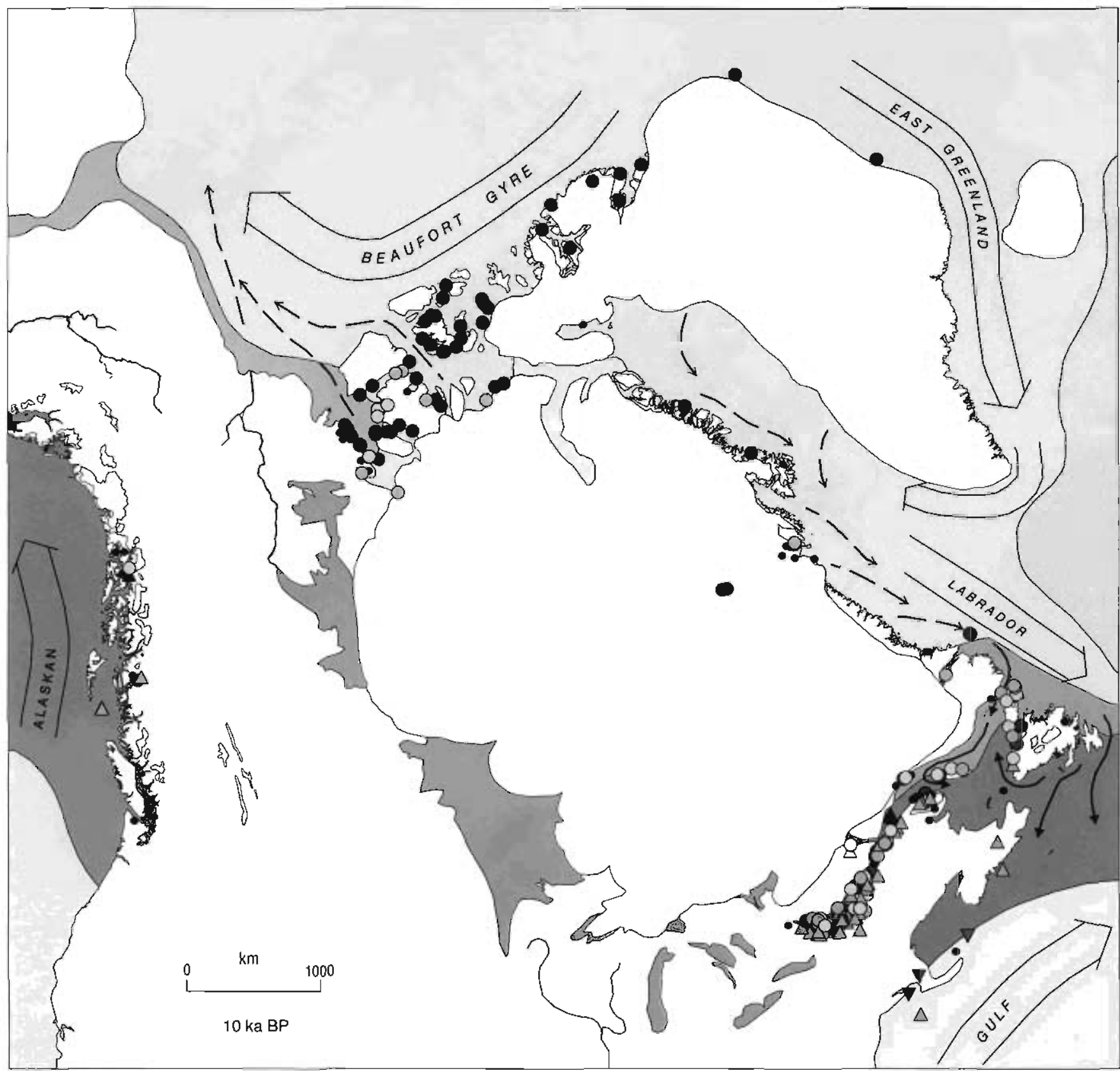

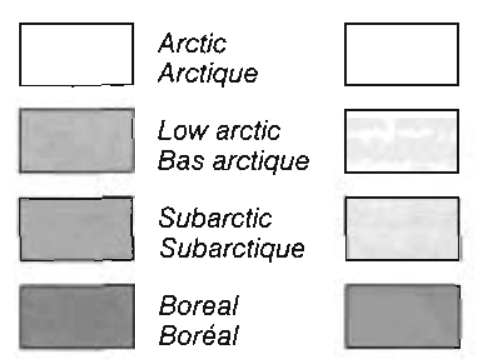

Temperate Tempéré

lae shelf

Plate-forme glaciaire

Undefined Indéfini

Fresh water

Eau douce
Restricted arctic Arctique restreint. . . Diverse arctic Arctique varié. ..... Arctic with boreal Arctique-boreal. . . . 0 Boreal with arctic Boréal-arctique.... Boreal

Boréal
Virginian; boreal with virginian

Virginien; boréal-virginien. . .

Widespread; species not identified

Répandu; espèces non identifiées . . . . . . . . . . .

Surface water flow

Circulation des eaux de surface.

Meltwater driven circulation

Circulation résultant des eaux 

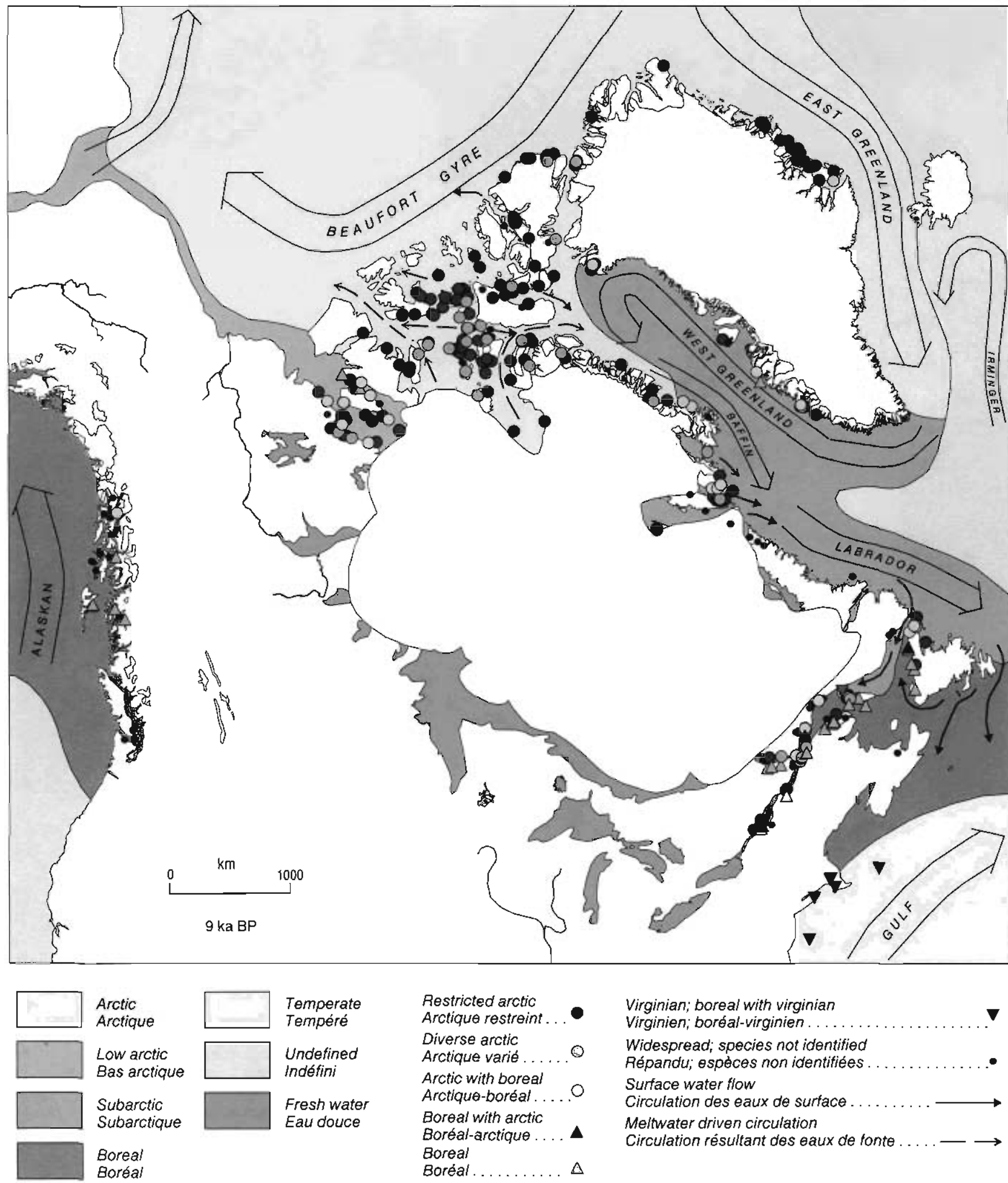

Restricted arctic

Arctique restreint. .

Diverse arctic

Arctique varié .....

Arctic with boreal

Arctique-boréal .....

Boreal with arctic

Boreal-arctique.... $\Delta$

Boreal

Boreal
Virginian; boreal with virginian

Virginien; boréal-virginien

Widespread; species not identified

Répandu; espécess non identifiées.

Surface water flow

Circulation des eaux de surface . . . . . . . . . $\longrightarrow$

Meltwater driven circulation

Circulation résulfant des eaux de fonte . . . . - $\longrightarrow$
FIGURE 25. Molluscan faunistic zones at 9 ka BP. Plotted samples date $9-9.99$ ka BP.
Zones fauniques des mollusques a $9 \mathrm{ka} B P$. Les âges des échantillons sont répartis de 9-9,99 ka BP. 

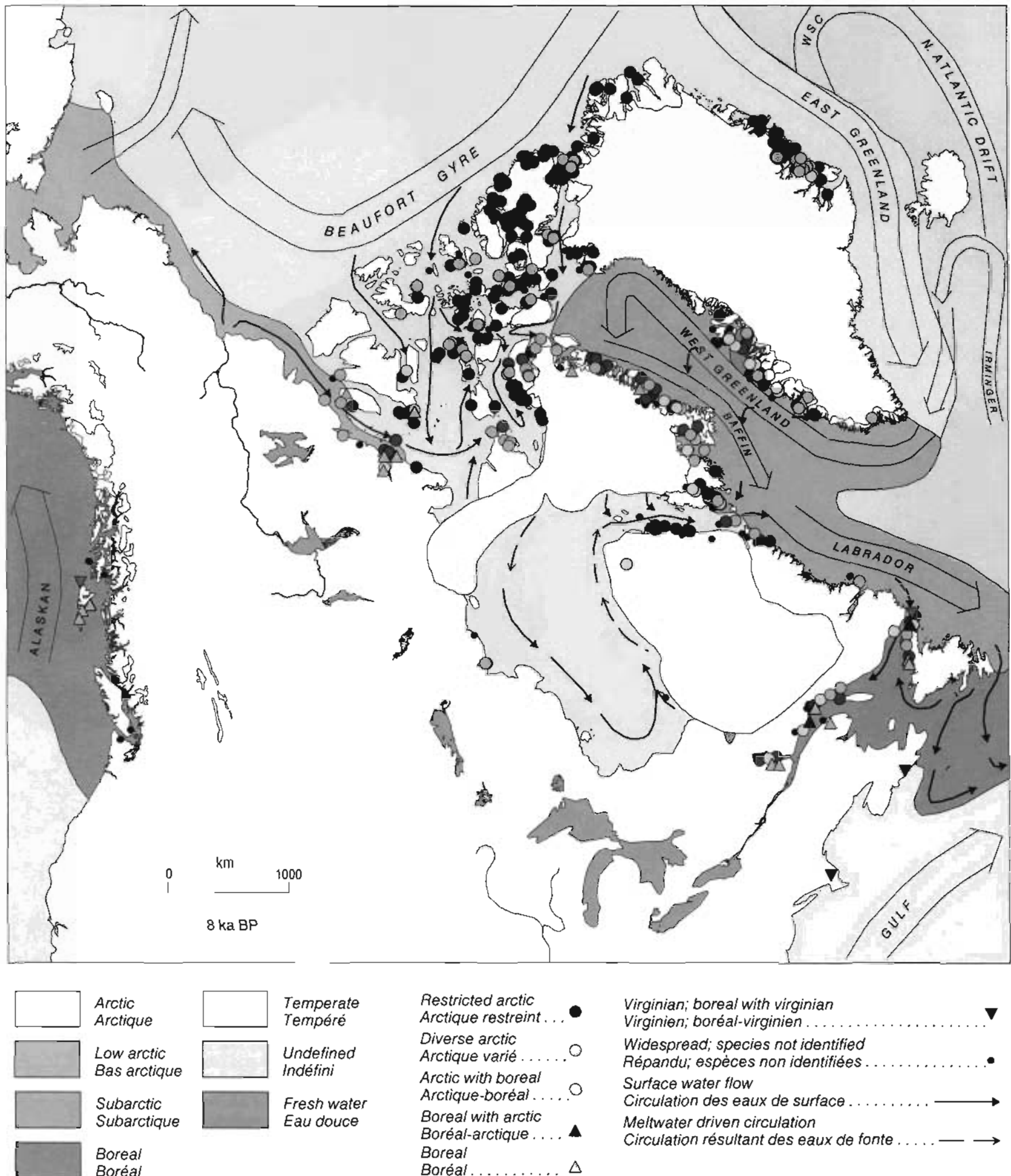

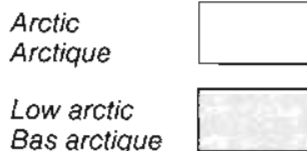

Bas arctigue

Subarctic

Subarctique

Boreal

Boréal
Temperate

Tempéré

\section{Undefined} Indéfini

Fresh wate

Eau douce
FIGURE 26. Molluscan faunistic zones at $8 \mathrm{ka}$ BP. Plotted samples date 8-8.99 ka BP.
Festricted arctic Arctique restreint

Diverse arctic

Arctique varié ..... 0

Arctic with boreal

Arctique-boréal.....

Boreal with arctic

Boréal-arctique. .

Boreal

Boréal . A
Virginian; borea/ with virginian

Virginien; boréal-virginien

Widespread; species not identified

Répandu; espèces non identifiées.

Surface water flow

Circulation des eaux de surface . . . . . . . . . $\longrightarrow$

Meltwater driven circulation

Circulation résultant des eaux de fonte . . . . - $\longrightarrow$
Zones fauniques des mollusques à $8 \mathrm{ka} B P$. Les âges des échantillons sont répartis de $8-8,99 \mathrm{ka} \mathrm{BP}$. 

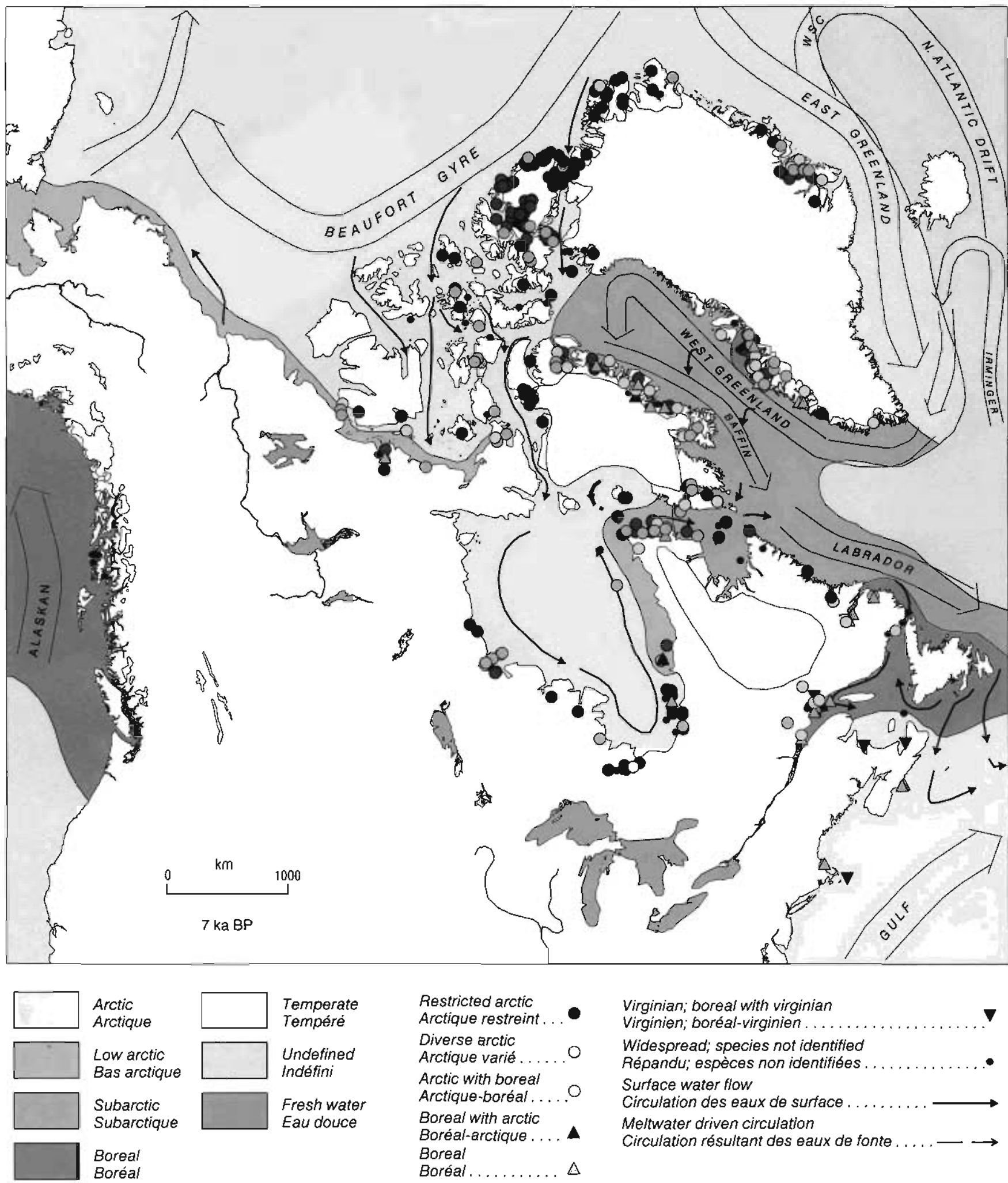

Restricted arctic

Diverse arctic

Arctique varié..... 0

Arctic with boreal

Arctique boréal....

Boreal with arctic

Boréal-arctique.... A

Boreal

Boréal
Virginian; boreal with virginjan

Virginien; boréal-virginien . ................

Widespread; species not identified

Répandu; espèces non identifieses.

Surface water flow

Circulation des eaux de sufface.

Meltwater driven circulation

Circulation résultant des eaux de fonte. .....- $\rightarrow$
FIGURE 27. Molluscan faunistic zones at 7 ka BP. Plotted samples date 7-7.99 ka BP.
Zones fauniques des mollusques a $7 \mathrm{ka}$ BP. Les âges des $6 \mathrm{chan}-$ tillons sont rópartis de $7.7,99 \mathrm{ka} \mathrm{BP}$. 


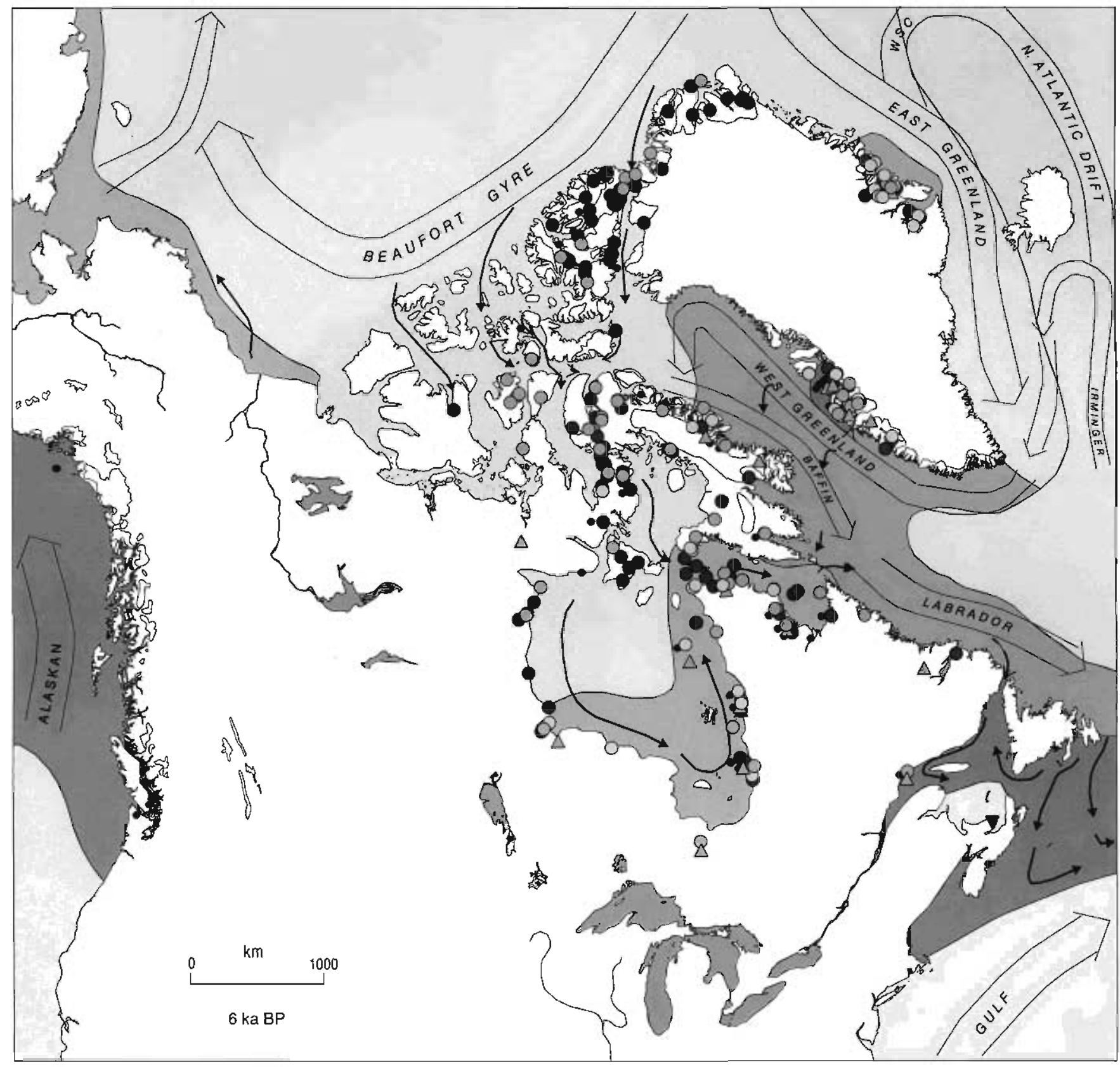

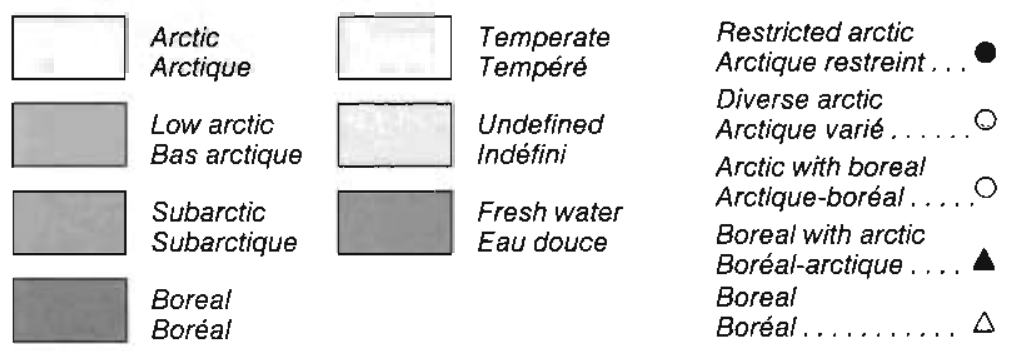

Virginian; boreal with virginian Virginien; boréal-virginien

Widespread; species not identified

Répandu; espéces non identifièes.

Surface water flow

Circulation des eaux de surface . . . . . . . . . $\longrightarrow$

Meitwater driven circulation

Circulation résultant des eaux de fonte . . . . - $\longrightarrow$
FIGURE 28. Molluscan faunistic zones at $6 \mathrm{ka}$ BP. Plotted samples date 6-6.99 ka BP.
Zones fauniques des mollusques à $6 \mathrm{ka}$ BP. Les agges des échantillons sont réparis de 6-6,99 ka $B P$. 


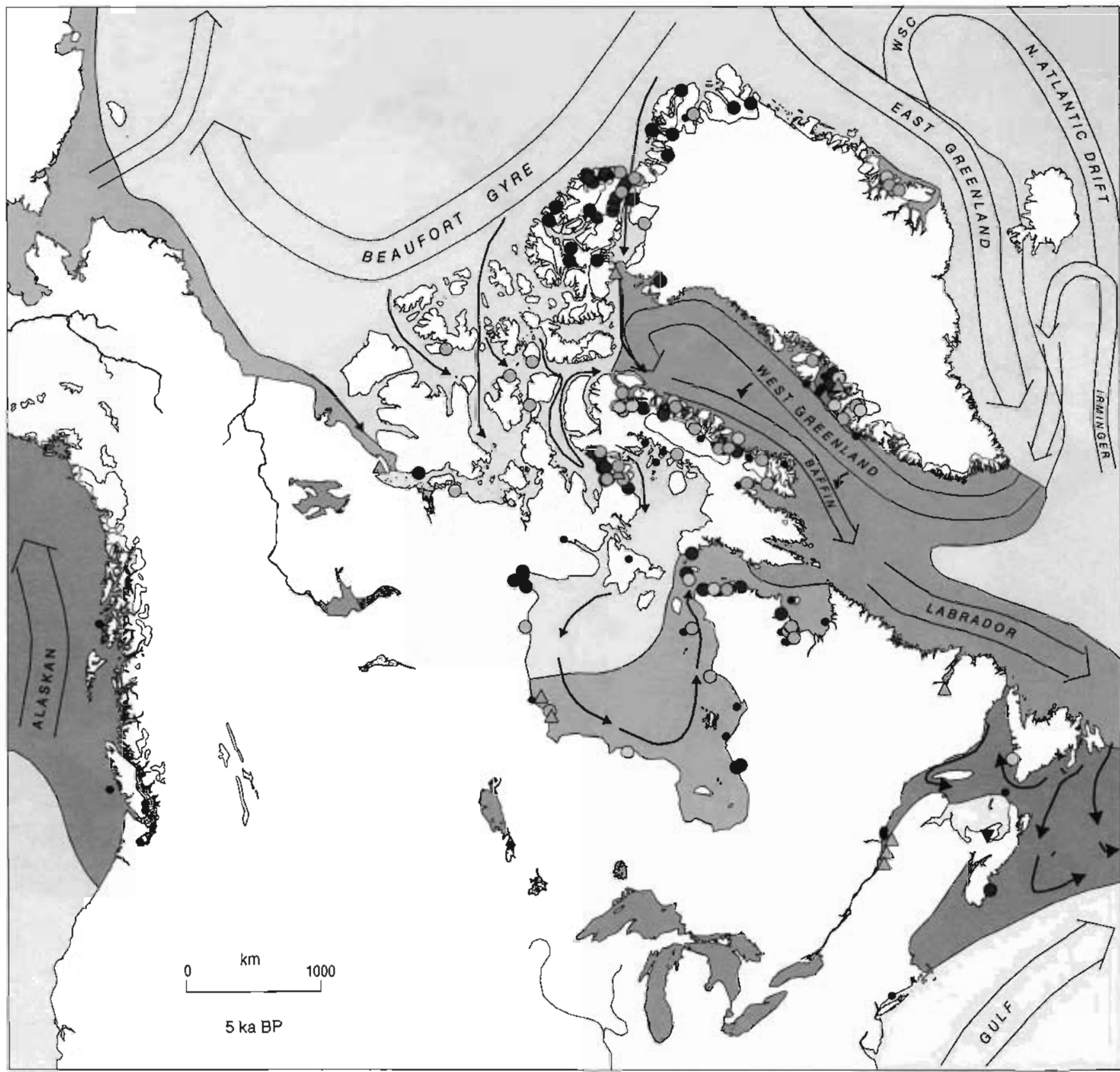

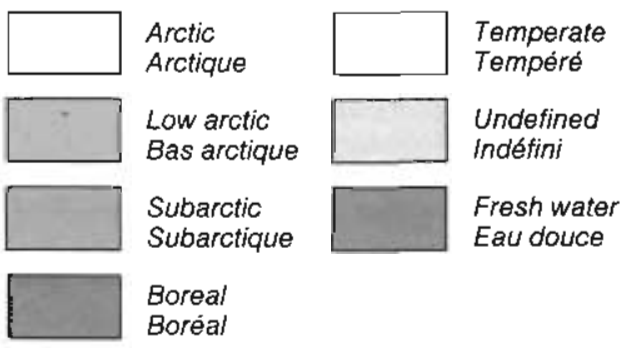

Restricted arctic Arctique restreint...

Diverse arctic Arctique varié . . . . . Arctic with boreal Arctique-boreal.... Boreal with arctic Boréal-arctique...
Boreal

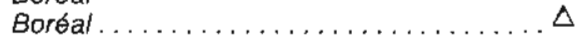

Virginian; boreal with virginian

Virginien; boréal-virginien.........

Widespread; species not identified

Répandu; espèces non identifiées . . . . . . . .

Surface water flow

Circulation des eaux de surface.
FIGURE 29. Molluscan faunistic zones at 5 ka BP. Plotted samples date $5-5.99 \mathrm{ka} \mathrm{BP}$.
Zones fauniques des mollusques à $5 \mathrm{ka}$ BP. Les âges des échantillons sont répartis de $5-5,99 \mathrm{ka} \mathrm{BP}$. 

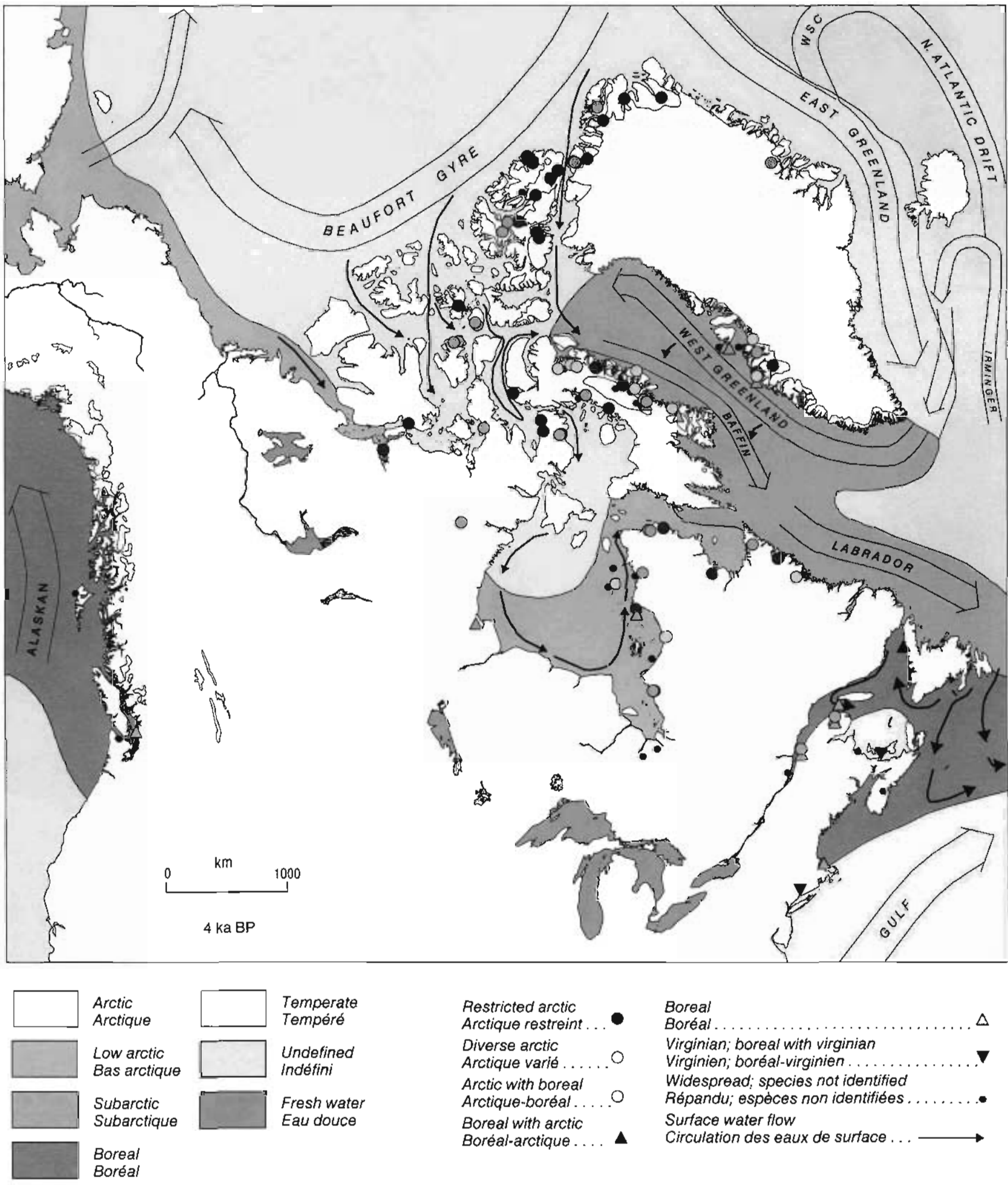

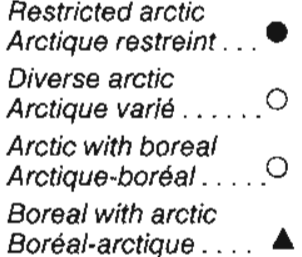

Boreal

Boréal . . . . . . . . . . . . . . .

Virginian; boreal with virginian

Virginien; boréal-virginien . .

Widespread: species not identified

Répandu; espèces non identifiées. . . . . . . .

Surface water flow

Circulation des eaux de surface. .
FIGURES 30. Molluscan faunistic zones at $4 \mathrm{ka}$ BP. Plotted samples date 4-4.99 ka BP.
Zones fauniques des mollusques à $4 \mathrm{ka} \mathrm{BP}$. Les âges des échantillons sont répartis de 4-4,99 ka BP 

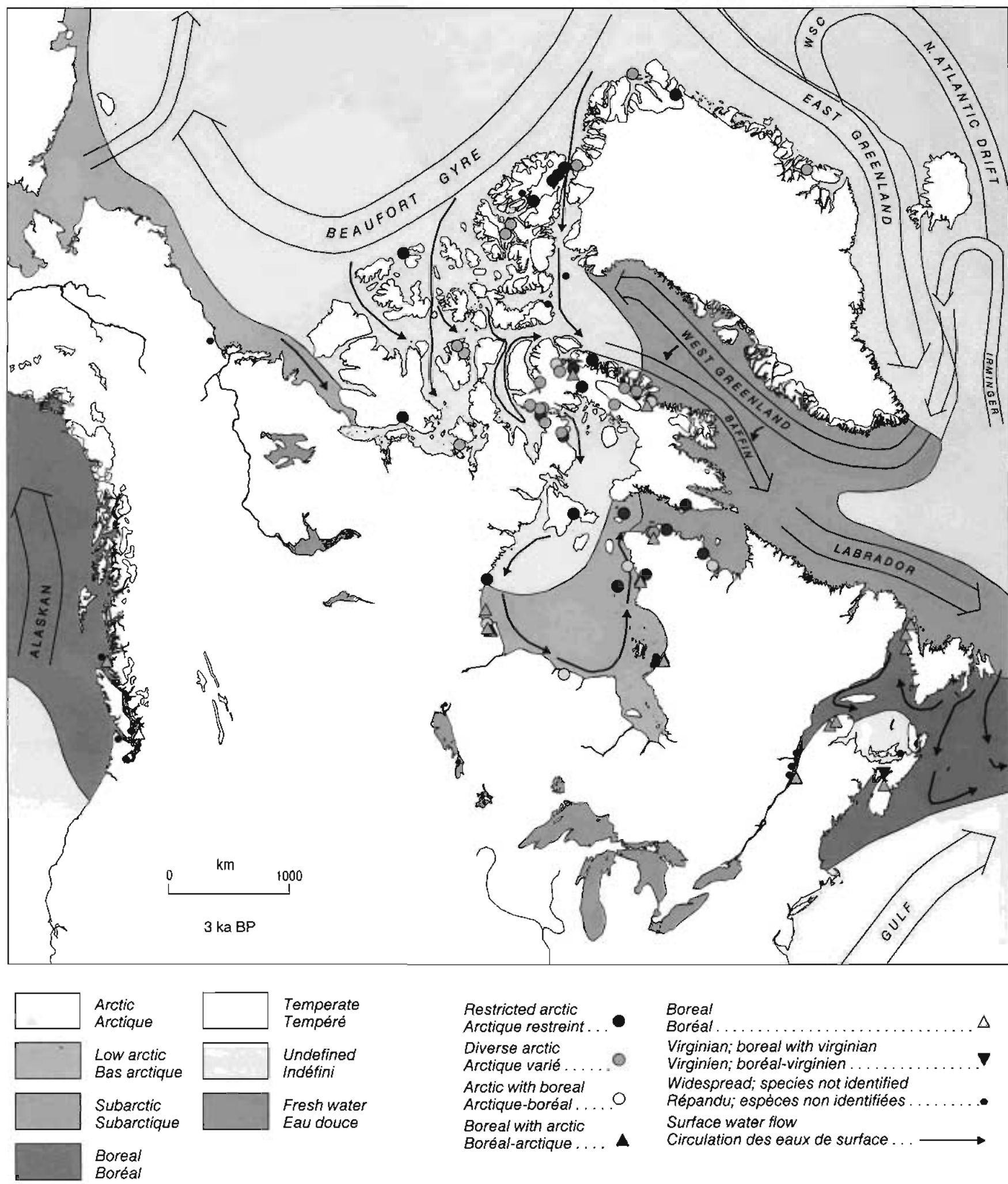

Restricted arctic Asctique restreint. . .

Diverse arctic Arctique varlé. ..... Arctic with boreal Arctique-boréal..... 0 Boreal with arctic Boréal-arctique....
Boreal

Boréal ....................... $\triangle$

Virginian; boreal with virginian

Virginien; borelal-virginien

Widespread; species not identified

Répandu; espéces non identifieses

Surtace water flow

Circulation des eaux de surface.
FIGURE 31. Molluscan faunistic zones at 3 ka BP. Plotted samples date 3.3 .99 ka $\mathrm{BP}$.
Zones fauniques des mollusques à $3 \mathrm{ka} \mathrm{BP}$. Les âges des bchantillons sont répanis de 3-3,99 ka BP. 

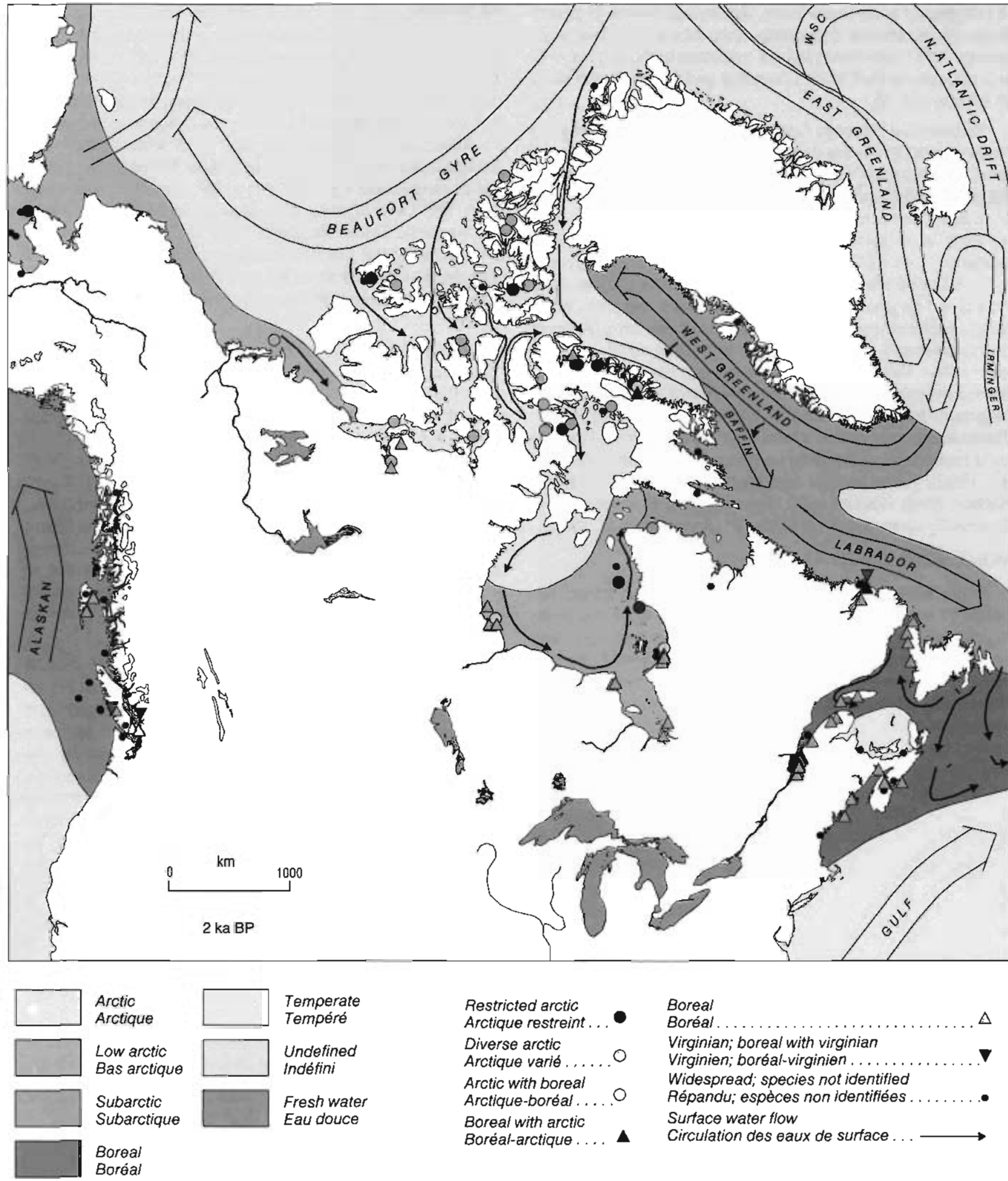

Boreal

Boréal . . . . . . . . . . . . . . . . . . .

Virginian; boreal with virginian

Virginien; boréal-virginien

Widespread; species not identifled

Répandu; especes non identifiées

Surtace water flow

Circulation des eaux de surface ... $\longrightarrow$

Boráal

FIGUPE 32. Molluscan faunistic zones at $2 \mathrm{ka}$ BP. Plotted samples date $0-2.99 \mathrm{ka} \mathrm{BP}$.
Zones fauniques des mollusques à $2 \mathrm{ka} \mathrm{BP}$. Les áges des échantillons sont répartis de 0-2,99 ka BP. 
in non-diluted arctic fiords today (Aitken and Gilbert, in press). Subarctic conditions supporting arctic faunas with boreal elements and local boreal faunas prevailed along the ice contact zone of the Gulf of St. Lawrence and the northeast coast of Newfoundland.

Widespread molluscs first appear in the Arctic during this interval, most in the western arctic islands and adjacent mainland. As discussed in the section on regional mollusc assemblages, samples exclusively record Hiatella arctica with three exceptions; one each record Portlandia arctica and Mya truncata. More surprising is the record of the boreal Macoma balthica (11.4 ka BP) which at this time could only have come in from the Pacific or from the Atlantic via the Barents Sea. As this is $1 \mathrm{ka}$ ahead of other Pacific arrivals and problematically early for submergence of Bering Strait, the sample should be re-examined to confirm that it is not the more common and similar Macoma calcarea. A sample placed well inside the ice margin in Hudson Strait consists of unidentified shell fragments from till on Akpatok Island dated at $11.97 \mathrm{ka} \mathrm{BP}$. These apparently record a brief opening of the strait followed by a readvance of ice onto southern Baffin Island (Gray et al., 1993). Foraminiferal and diatom records of cores off Hudson Strait indicate fairly high biological productivity and seasonally open water 12-11 ka BP (Andrews et al., 1990).

\section{MOLLUSCAN ZONES AT $10 \mathrm{ka} \mathrm{BP}$}

There were important changes in molluscan zones between 11 and $10 \mathrm{ka} \mathrm{BP} \mathrm{(Fig.} \mathrm{24).} \mathrm{We} \mathrm{discuss} \mathrm{them} \mathrm{in} \mathrm{a} \mathrm{south}$ to north sequence'. The first dated Virginian taxa appeared on the submerging New England shelf between $11 \mathrm{ka}$ and $10 \mathrm{ka} \mathrm{BP}$, where only boreal species were reported previously. Hence, the warming effect of the Gulf Stream extended farther north and coastward than before, perhaps simply because of progressive inundation of the outer shelf or perhaps because of enthanced warming during the summer insolation maximum of the late Pleistocene - early Holocene (Berger. 1978). The oyster (Crassostrea virginica) requires minimum summer temperatures of $20^{\circ} \mathrm{C}$ for spawning.

The faunal record of the outer Gulf of St. Lawrence is impoverished by $10 \mathrm{ka}$ BP because of ongoing submergence. This precludes examination of the molluscan response to the Younger Dryas cooling recorded in pollen assemblages in the Maritimes (Mott et al. 1986) and in foraminiferal assemblages in the central North Atlantic (Ruddiman, 1987). However, the western extension of the gulf, the Champlain Sea, has welldated molluscan faunas. These can still be characterized as boreal, but a relatively larger proportion of samples record arctic faunas between 10.9 and $10 \mathrm{ka} \mathrm{BP}$ than before. This is surprising in light of the early concept of a Hiatella arctica phase succeeded by a Mya arenaria phase (Elson, 1969b). $Y$ ef a general cooling of the sea may be expected in light of

1. The two samples placed tar inside the ice margin in Hudson Strait are regionaily anomalous. One is a date on shell fragments from the till surface and may, therefore, be on shells of mixed ages. The other is one of several dates on a thin bed of shells in a delta that have yielded ages with a variance of about 2000 years that remains unexplained (Gray et al., 1993). the changing discharge into it from the west: from 11-10 ka $\mathrm{BP}$, the entire proglacial lake sequence west to Lake Agassiz drained into the sea via Lake Ontario and the Ottawa Valley (Clayton and Moran, 1982; Teller and Clayton, 1983; Teller. 1985, 1987; Dyke and Prest, 1987; Teller, 1990; Rodrigues and Vilks, 1994). Before $11 \mathrm{ka} \mathrm{BP}$, Lake Agassiz drained via the Mississippi River into the Gulf of Mexico. It had been thought that flow returned to the Gulf of Mexico atter blockage of eastern outlets about $9.9 \mathrm{ka} \mathrm{BP}$. However, it now appears that Lake Agassiz discharged northward at that time into the Arctic Ocean via glacial Lake McConnell (Fisher and Smith, 1995), that this flow continued until re-establishment of eastward drainage about $9.5 \mathrm{ka} \mathrm{BP}$, and that meltwater flow never resumed down the Mississippi River (Marchitto and Wei, 1995).

Because the eastward diversion of Agassiz waters into the Champlain Sea correlates with the Younger Dryas cooling recorded in pollen records on both sides of the North Atlantic and with a $15^{\circ}$ latitude southward shift of the marine polar front in the North Atlantic, the diversion has been invoked as the causal mechanism of the cooling (Broecker et al., 1989). The Agassiz meltwater, in this view, produced a cold, "fresh" water lid on the North Atjantic which dampened thermohaline circulation (bottom water production in the northern North Atlantic) and consequently northward advection of subtropical surface waters. If the freshening effect was so strong in the open ocean, there should have been a strong response in the relatively small Champlain Sea itself, through which all the water passed.

The suggestion of a more "arctic" fauna at 10-11 than at 11-12 ka BP in the Champlain Sea (ct. Fig. 23 and 24) invites a closer comparison of data for pre-Younger Dryas and Younger Dryas intervals (Table IX). Both are well dated, with 75 and 94 samples, respectively, and with essentially the same suite of taxa. The boreal Mya arenaria increases strongly from the older interval to the Younger Dryas (as expected from Elson's biostratigraphy) whereas other boreal species, Macoma balthica and Balanus hameri, decrease. The largest change is the marked increase during the Younger Dryas in the proportion of samples reporting Hiatella arctica, especially those reporting that species only.

\section{TABLE IX}

Abundances of common marine invertebrates of the Champlain Sea as percentage presence in samples from the Younger Dyras cold interval and the preceding interval

\begin{tabular}{lcc}
\hline Species & $\begin{array}{r}11-11.99 \mathrm{ka} \mathrm{BP} \\
(\mathrm{n}=75\end{array}$ & $\begin{array}{c}\text { 10-10.99 ka BP } \\
\text { (n=94 samples) }\end{array}$ \\
\hline Macoma ballhica & 47.0 & 29.8 \\
Hiatella arcfica tolal & 24.0 & 44.7 \\
Hiatella arctica alone & 6.7 & 22.3 \\
Balanus hamer & 22.7 & 11.8 \\
Portlandia arctica & 12.0 & 11.8 \\
Mytilus edulis & 6.7 & 8.5 \\
Mya arenaria & 2.7 & 18.1 \\
Mya truncata & 4.0 & 6.4 \\
Macoma calcarea & 1.3 & 7.4 \\
\hline
\end{tabular}


These faunal changes are not likely artefacts of sampling, given the attention that Champlain Sea faunas have received. In that Rodrigues and Richard (1986) linked $M$. balthica and $B$. hameri in this sea to high salinity bottom waters, their decrease can be seen as compatible with Agassiz-induced freshening, although the former is euryhaline. Similarly, $M$. arenaria prefers brackish conditions (Wagner, 1959). $\mathrm{H}$. arctica could tolerate both water mass cooling and seasonally changing salinities. Thus the faunal changes broadly suggested on Figure 24 and outlined more fully in Table IX are compatible with the history of discharge into the Champlain Sea although they are not necessarily diagnostic of it. However, Rodrigues and Vilks (1994) provided a different analysis of the effects of Agassiz discharge on the Champlain Sea and Gulf of St. Lawrence. They recognized freshening of the Champlain Sea, but only after $10.5 \mathrm{ka} \mathrm{BP}$, and suggested that this could also be explained by shallowing as uplift progressed. Agassiz runoff through the Gulf of St. Lawrence during the Younger Dryas occurred during a broader interval (12.1-8.7 ka BP) of low salinity bottom waters there. The Agassiz outflow apparently did not mix with bottom water. In their assessment, Agassiz outtlow did not trigger Younger Dryas cooling.

The Arctic faunal record by $10 \mathrm{ka} \mathrm{BP}$ is more widely distributed than previously. The restricted arctic assemblage still dominates on both Baffin Bay and Arctic Ocean sides. However, in the southwestern arctic islands, we define a low arctic molluscan zone due to the presence in several samples of Mytilus edulis and Macoma balthica and reportedly Mya arenaria. Although we regard the latter as dubious, the presence of the other species requires that Bering Strait was open, as discussed earlier, and that these waters were warmer than present despite meltwater effects (Andrews et al, 1993), including the considerable discharges of lakes Agassiz and McConnell. Because there are no extra-regional currents to import warm water to this region (even with Bering Strait open), we infer greater seasonal warming than occurs today. This is not problematic in that a woodland existed north of present treeline in the Mackenzje Delta area by $11 \mathrm{ka} \mathrm{BP}$ and Northern Hemisphere summer insolation was at a maximum at $10 \mathrm{ka}$ BP (Ritchie et al., 1983; Ritchie, 1989).

The molluscan chronology of the Canadian Arctic places the opening of Bering Strait at 10.5-10.3 ka BP (dates corrected for reservoir age of 400 years). Submergence of the strait is not well dated directly and the molluscs may provide the best age control available. The deepest part of the sill is shallower than $50 \mathrm{~m}$ and Fairbanks' (1989) eustatic curve for Barbados would place the sea rising to that level about $9.5 \mathrm{ka}$ BP. However, hydro-isostatic deformation imparts a variable eustatic sea level history to extra-glacial regions (Walcott, 1972; Tushingham and Peltier, 1991) which makes it unlikely that the Barbados curve would precisely apply to Bering Strait. Furthermore, it is improbable that thermophilous molluscs arrived in the western Canadian Arctic at $10.3 \mathrm{ka}$ BP from the Allantic via North Greenland without leaving any record of this passane. Therefore, we suggest they provide a minimum age on the opening of Bering Strait. This opening is important to the history of the Arctic Ocean because it marks the first postglacial inflow of Pacific water to the head of the
Transpolar Drift and contribution to formation of Arctic Ocean surface water as today.

Although $M$. edufis remains in this area today, Lubinsky (1980) includes the southwest Canadian Arctic in her High Arctic Faunistic Zone (region III). However, the region bears strong similarity to the Low Arctic Faunistic Zone in its greater seasonal warming of littoral waters due to continental runoff and to higher summer temperatures as evidenced by the proximity of the region to treeline. In the Atlantic the northern limit of $M$. edulis marks the boundary between arctic and subarctic, and in Hudson Bay between high arctic and low arctic. For consistency in interpreting the fossil record, we exclude Mytilus-bearing regions from the high arctic zone

The only diverse arctic assemblages recorded for this interval in the western Arctic occur in the belt adjoining the low arctic zone. This suggests a coherent spatial pattern of high arctic species diversification, the equivalent of the temporal diversification suggested by the regional arctic records. If so, the postglacial arctic diversification wave, including the spread of $M$. truncata, may have originated in the Pacific. Elsewhere in arctic Canada and Greenland, only Hiatelia arctica and Mya truncata occur, with the former being strongly dominant. Feyling-Hanssen and Olsson (1960) reported that raised marine terraces of Billefjorden, Spitsbergen older than $10 \mathrm{ka}$ BP likewise contain $H$. arctica and $M$. truncata only. Thus, the restricted arctic assemblage may have dominated much of the Arctic Ocean until about $10 \mathrm{ka} \mathrm{BP}$.

Because of interest in the Younger Dryas cool interval, particularly its hemispheric or even global occurrence, we have examined all the molsuscan data for this interval. We recognize credible evidence of freshening and probably cooling in the Champlain Sea, a strong suggestion of warming off New England in the advance of Virginian taxa, and clear evidence of warmer than present marine conditions along the western arctic mainland despite its ice-proximal setting. This is not supportive of a hemispheric Younger Dryas event. Our interpretations clearly do not challenge the proposal of a meltwater trigger via the Champlain Sea for the Younger Dryas cooling. However, Andrews et al. (1990) regarded that as an insufficient mechanism. They recognized diatom- and foraminifera-barren zones of Younger Dryas age in cores off Hudson Strait and postulated a major correlative glacial readvance into seas with either an ice shelf or with summerpersistent sea ice. They speculated, along with Mifler and Kaufman (1990), that enhanced calving of ice bergs off Hudson Strait during the glacial advance triggered the Younger Dryas cooling. However, that cooling does not then explain the Laurentide advance (11.5-10.5 ka BP) which may invoke cooling by another mechanism.

\section{MOLLUSCAN ZONES AT $9 \mathrm{ka}$ BP}

Important changes in oceanographic conditions occurred between 10 and 9 ka BP. mainly in arctic areas (Fig. 25). At $9 \mathrm{ka} \mathrm{BP}$. warm temperate (Virginian) faunas appear to have held their previous distribution off New England. However, the sparse record suggests a farther northward advance, as might be expected from continuing submergence of the continental shelf. 
Arctic elements, mostly Hiatella arctica, occurred in the late phase Champlain Sea. This may be due to continued salinity and temperature effects of discharge from glacial lakes. Portlandia arctica, which today ranges south to Hamilton Inlet, was present in proglacial Lac Saint-Jean basin. Other than these local effects, the Gulf of St. Lawrence faunal record appears similar to today and probably warmer than at $10 \mathrm{ka}$ $\mathrm{BP}$, perhaps due to continued ice sheet retreat inland. The local faunas of the west coast of Newfoundland and the St. Lawrence estuary present a more boreal aspect than previously. No range extensions are involved except for an oyster Crassostrea virginica reported from the north shore of the gulf. But this shell is not directly dated and occurs in add association with the dated Mya truncata (UQ-1375).

The eastern arctic record is highly informative by $9 \mathrm{ka} B \mathrm{P}$. Funder and Weidick (1991) showed that the extension of Mylilus edulis and Chlamys islandica to the Thule area of northwest Greenland requires that the West Greenland Current was established by $9.1 \mathrm{ka} \mathrm{BP}$. The occurrence of $C$. islandica in southwest Greenland at $9.4 \mathrm{ka} \mathrm{BP}$ indicates that the current extended at least into Davis Strait by then. $M$. edulis also extended farther up the Baffin coast by $9 \mathrm{ka} \mathrm{BP}$ than it does today.

A warm West Greenland Current requires presence of the Irminger Current, the branch of the North Atlantic Dritt that provides warm water to it (Fig. 25). The Irminger Current probably started to influence the northeastern Labrador Sea about $10 \mathrm{ka}$ BP when warm-water dinoflagellates increased (De Vernal and Hillaire-Marcel, 1987). Similarly establishment of a suite of boreal molluscs in Svalbard after $10 \mathrm{ka} \mathrm{BP}$, including $M$. edulis and $C$. islandica, (Feyling-Hanssen and Olssen, 1960) signals establishment of the North Atlantic Drift and the warm West Spitsbergen Current. The oldest radiocarbon dates on $M$. edulis from Svalbard are $9375 \pm 80 \mathrm{BP}$ (DIC3076; Forman, 1990) and 9360 $110 \mathrm{BP}$ (T-3098; Salvigsen and Osterholm, 1982); a sample containing $C$. islandica dated $9535 \pm 90 \mathrm{BP}$ (DIC-3055; Forman, 1990). These dates suggest that these animals entered central East Greenland from Svalbard, as inferred by Hjort and Funder (1974). West Greenland and the eastern Canadian Arctic may have been settled by boreal mollusc larvae arriving broadly from Spitsbergen and Iceland via the West Spitsbergen, Irminger, and West Greenland currents. Although both $M$. edulis and $C$. islandica were present in the Gulf of St. Lawrence well before $10 \mathrm{ka}$ $\mathrm{BP}$, the Labrador Current would have hampered northward dispersion.

A southward flow along the Baffin Island shore, a Baffin Current, must also have formed as the West Greenland Current became established. But the chilling effect of this current along the north coast of Cumberland Peninsula was less severe than it is today. It possibly was mitigated by greater admixture of water from the West Greenland Current or greater seasonal warming of the littoral zone during a longer summer ice-free period (Fig. 25). Melt rates on the Devon and Agassiz ice caps in the Canadian high arctic were at a maximum in the early Holocene (Koerner, 1989; Koerner and Fisher, 1990; Fisher et al., 1995) and the greater summer heating implied can probably explain the range extension (relative to present) of Astarte striata and $M$. edulis along Cumberland Peninsula. Dinoflagellate and foraminiferal records from southern Baffin Bay also indicate warmer conditions, possibly because of little Arctic water flow into northern Baffin Bay to form Baffin Bay Bottom Water (Aksu and Mudie, 1985).

Because eastern Baffin Island has an important record of molluscan range extensions and retractions, we summarize regional oceanographic variability at this point. A number of factors can influence the temperature of coastal waters along eastern Baffin Island: (1) the thickness of the cold, low-salinity, surface water flow in the Baffin Current, largely derived now from outflow of surface water from the Arctic Ocean, (2) the sea-ice load of that current, (3) the relative contribution of warm water from the West Greenland Current to the inner Baffin shelf and its depth of flow, and (4) the relative contribution of warm bottom water of Atiantic origin flowing out at depth from the Arctic Ocean via the Queen Elizabeth Islands. Williams et al. (1995) pointed out that postglacial uplift of the Queen Elizabeth Islands has led to a steadily diminishing flow of deep Atlantic water from the Arctic Ocean into Baffin Bay. The inflow of Pacific water through Bering Strait would also have affected the character of outflowing Arctic Ocean water in the upper $200 \mathrm{~m}$. The sea-ice load carried by the Baffin Current is dictated partly by the pattern of summer ice clearance in the arctic islands.

Dyke and Morris (1990) and Dyke et al. (in review a, b) concluded for several reasons that surface water flow from the Arctic Ocean to Baffin Bay started at 8.6-8.5 ka BP. It was not until then that driftwood was carried into the Canadian Arctic Islands from the Arctic Ocean. Before then driftwood entry was prevented in spite of widespread bowhead whale penetration. Furthermore, driftwood was arriving at Svalbard via the Arctic Ocean before $8.5 \mathrm{ka} 8 \mathrm{P}$. They concluded that a meltwater-driven surface water outflow from the islands exported sea ice, allowing access by whales, while deflecting driftwood before $8.5 \mathrm{ka} 8 \mathrm{P}$.

Considering these constraints and the factors listed above, we can suggest some likely oceanographic conditions, in addition to greater solar heating, that could have made coastal waters of western Baffin Bay warmer than present during the early Holocene. The Baffin Current probably comprised only a thin melswater-derived surface layer that flowed above warmer water derived from the West Greenland Current, from Atlantic water exiting the Arctic Ocean, or from both. The meltwater-derived layer was sufficiently thin that the warmer water below was able to affect the nearshore zone, thus its moltuscs. The mollusc record seems at odds with William's (1990) conclusion of severe summer sea-ice conditions in western Battin Bay during the early Holocene. However, this may arise in part from uncertain core chronologies.

Conditions in the western Arctic at 9 ka were similar to those at $10 \mathrm{ka} \mathrm{BP}$. The low arctic zone was dominated by restricted and diverse arctic local faunas but Mytilus edulis occurred in its maximum postglacial abundance, even in the periglacial zone. Thus, coastal waters were probably warmer than during the preceding interval and than at present. 
Molluscs were very widespread throughout the Canadian Arctic Islands and along North and East Greenland by $9 \mathrm{ka}$ BP. Hiatella arctica was regionally dominant, Mya truncata was common, and diverse arctic assemblages were widespread, though perhaps not in the Sverdrup Islands region. That region apparently never cleared of sea ice in the summers sufficiently to allow reliable entry of bowhead whales at any time during the Holocene (Dyke et al., in review b) and panarctic molluscs have a restricted distribution there today (Lubinsky, 1980).

\section{MOLLUSCAN ZONES AT $8 \mathrm{ka} \mathrm{BP}$}

Molluscan zones shifted significantly between 9 and $8 \mathrm{ka}$ BP (Fig. 26). These shifts can not be explained simply by deglaciation so we seek oceanographic explanations. The largest and best documented changes were in the Arctic but zones also appear to have shifted along the Atlantic. We argue in this section that $8.5 \mathrm{ka}$ BP was a time of profound change in polar regions with repercussions in middle latitudes.

The record of shifting zones off the Atlantic Provinces is tentative but suggests a further northward expansion of temperate molluscs by $8 \mathrm{ka} \mathrm{BP}$. The gastropod Polinices heros is recorded off Nova Scotia at $8.83 \mathrm{ka} \mathrm{BP}$, the earliest Virginian recorded so far north. However, it ranges into southwestern Gulf of St. Lawrence today and thus does not represent a range extension with respect to present. A probable range extension is recorded by the pelecypod Mysella planulata in a sample dating $8.28 \mathrm{ka}$ BP from the north shore of the St. Lawrence estuary (Bigras et Dubois, 1987). It ranges today from southwestern Gulf of St. Lawrence to Texas. A larger range extension is recorded by Spisula solidissima in a sample from St. Anthony, northernmost Newfoundland dated at $8.17 \mathrm{ka} \mathrm{BP}$ (Robertson, 1987). This bivalve today ranges from South Carolina to Nova Scotia. Its occurrence at a site now strongly affected by the Labrador Current is highly significant though additional records of this extension should be sought.

Bearing in mind that the regional record for this interval is difficult to sample due to submergence, we take the foregoing as evidence that the temperate zone by $8 \mathrm{ka} \mathrm{BP}$ had expanded well up the shallowly submerged Scotian Shelf; the boreal environment of the Gulf of St. Lawrence had expanded and warmed enough for entry of a few temperate taxa. This suggests that the cooling influence of the Labrador Current on the north shore of the gulf was lessened. We can reasonably invoke diminished inflow of water from the Labrador Current due to shaflowing of the Strait of Belle Isle, increased inflow and upwelling of Atlantic bottom water into the deepening southern gutf (Grant, 1989), or warming of the Labrador Current itself as suggested by the arctic data.

In order to explore possible feedbacks from region to region, we next discuss the eastern arctic molluscan record in a down-current sequence starting in East Greenland. Two thermophiles appeared in East Greenland by $8 \mathrm{ka} \mathrm{BP}$, one extinct in the area now. However, the regional faunal record is so dominantly arctic that at $8 \mathrm{ka}$ BP perhaps the subarctic faunas were able to establish only in restricted enclaves. Yet initial colonization by $C$. islandica at $8.58 \mathrm{ka}$ BP is important. Boreal molluscs now extend to highest latitudes in the east- ern North Atlantic due to warming by the North Atlantic Drift (Fig. 26). Some of these had reached Spitsbergen by $9.4 \mathrm{ka}$ BP (Forman, 1990). Thus a reasonable mechanism for these animals reaching central East Greenland, well north of Iceland and the trminger Current, is transport of their larvae in the warm West Spitsbergen Current (Hjort and Funder, 1974). This requires that the West Spitsbergen Current had a greater influence on coastal northeast Greenland than previously and than it does today. Occupation of central East Greenland by Mytilus edulis indicates that this condition lasted till $5.5 \mathrm{ka} \mathrm{BP}$ (Hjort and Funder, 1974). In that the West Spitsbergen Current along East Greenland today flows outside of and below the East Greenland Current at about $150 \mathrm{~m}$ depth, the East Greenland Current may formerly have been thinner.

Increased influence of the West Spitsbergen Current on East Greenland may indicate its strengthening or a weakening flow of the Transpolar Drift to the East Greenland Current. A stronger West Spitsbergen Current could arise from generally increased transport of North Atlantic Drift waters. Abrupt nannofossil changes in a core off south Greenland are thought to indicate strengthening of the Irminger Current and North Atlantic Drift at $8.4 \mathrm{ka} \mathrm{BP}$ (Rahman and De Vernal, 1994). However, the Transpolar Drift may have shifted at the same time. Because the Transpolar Drift crosses the central Arctic Ocean and approaches the apex of northeast Greenland, a small lateral shift can divert much of it into the Beaufort Gyre, on the one hand, or into the East Greenland Current, on the other. Dyke et al. (in review a) suggested that shifts of the Transpolar Drift, which carries most driftwood across the Arctic Ocean, account for changing patterns of wood delivery to the Canadian Arctic and Svalbard. When the distal Transpolar Drift takes a more westward route both the East and West Greenland currents, and possibly the Baffin and Labrador currents will be warmer. The widespread onset of driftwood stranding in the Canadian Arctic Archipelago at 8.6$8.5 \mathrm{ka} \mathrm{BP}$ correlates with the initial arrival of thermophilous molluscs in East Greenland and may have a common cause.

Another, more remote, change at about $8.5 \mathrm{ka}$ BP may have profoundly affected the Transpolar Drift and systems down current. Until about $8.5 \mathrm{ka}$ BP much of the western Laurentide lce Sheet discharged meltwater into the Arctic Ocean via the Mackenzie River. At about $8.5 \mathrm{ka} \mathrm{BP}$, the ice margin withdrew from that watershed (Dyke and Prest, 1987). Mackenzie discharge apparently now affects sea ice and related conditions in the region from the Beaufort Sea to the Labrador Sea (Mysak and Manak, 1989; Mysak et al, 1990; Mysak and Power, 1991; 1992) so it probably also affected conditions in the past. Seasons of heavy discharge lead to increased sea ice production on the Beaufort Shelf because freshened surface water freezes at a higher temperature than shelf water. High Mackenzie discharges today result in increased sea ice discharge through Fram Strait 3-5 years later. This produces "Great Ice and Salinity Anomalies" (GISAs) in the Greenland-Iceland Sea that migrate through the Labrador Sea south to Newfoundland. As the Mackenzie switched from a glacial to a nonglacial river at $8.5 \mathrm{ka} B P$ reduction of discharge must have been orders of magnitude greater than any historic fluctuation. Hence, at $8.5 \mathrm{ka} \mathrm{BP}$ there must have 
been a great reduction in sea ice discharge through Fram Strait. This alone could have led to an increase in temperatures of currents downstream to the North Atlantic Drift.

Mackenzie-regulated ice discharge through Fram Strait has further feedbacks on climate (Mysak and Power, 1992). Great ice discharge into the Greenland-Iceland Sea freshens surface water on melting. This reduces convective overturning of water, heat transfer from the water, cyclogenesis in the North Atlantic, and precipitation in polar regions including the Canadian Arctic Islands. These feedbacks in the modern climate system strongly suggest that retreat of the Laurentide ice margin from the Mackenzie watershed, complemented by a reduction in glacial meltwater entering the adjacent archipelago (Andrews et al., 1993), could have triggered a general change in North Atlantic climate. We postulate a "Truly Great Ice and Salinity Anomaly" before $8.5 \mathrm{ka} \mathrm{BP}$ followed by the modern regime when the Greenland-Iceland Sea became warmer, more saline, and more convective and cyclogenesis became stronger and more frequent.

By 8 ka BP subarctic West Greenland was populated by Chlamys islandica and Mytilus edulis. Funder and Weidick (1991) also report the occurrence in part of southwest Greenland at this time of more thermophilous Panopea norvegica and Arctica islandica, now extinct there. The area of occurrence is related to regional submarine topography. The West Greenland Current carries both cold water from the East Greenland Current (running on the coastal side in southernmost West Greenland; Funder and Weidick, 1991) and warm water from the Irminger Current (Fig. 26). Shallow banks at $65^{\circ} \mathrm{N}$ now deflect the colder water and its sea-ice load westward into Davis Strait creating warmer conditions over the banks than farther south. The fossil mollusc record suggests that this pattern of separation of water masses by the banks started by $8.4 \mathrm{ka} \mathrm{BP}$, probably as postglacial sea level change established the critical water depths (Funder and Weidick, 1991). Thus, transport of cold water northward into Baffin Bay then decreased further by this effect.

Boreal molluscs extended along the entire east coast of Baffin Island by $8.2 \mathrm{ka} \mathrm{BP}$, almost $1000 \mathrm{~km}$ north of their present limit on that coast. The record is not detailed enough to reveal whether these animals extended their ranges northward between 9 and $8 \mathrm{ka}$ BP or settled the area from Greenfand. Because of their zoogeographic significance, any collection containing these range-extension indicators is almost certain to be radiocarbon dated. Thus, they are not underrepresented in the record. These boreal species may never have been able to exploit more than restricted niches along the northeast Baffin coast so the portrayal of general subarctic conditions in all of Baffin Bay at $8 \mathrm{ka} \mathrm{BP} \mathrm{(Fig.} \mathrm{26)} \mathrm{is} \mathrm{perhaps}$ too broad. Nevertheless, coastal marine conditions were certainly warmer than today or than they were at $9 \mathrm{ka} \mathrm{BP}$.

Conditions inferred for the Canadian Arctic Archipelago at 8 ka BP (Fig. 26; Dyke et al., in review b) may, at first glance. appear contradictory of those in Baffin Bay. By $8 \mathrm{ka}$ BP flow through the archipelago of surface water from the Arctic Ocean was established, replacing the previous meltwaterdominated outflow. A consequence of this change was that the inter-island channels became congested with sea ice which between $8 \mathrm{ka}$ and $6 \mathrm{ka}$ BP cleared only minimally in the summers, severely restricting the range of the bowhead whale. Although these "bad-ice summers" in the archipelago may appear to contradict warm conditions in Baffin Bay, we suggest that retention of sea ice in the archipelago would have reduced the ice load of the Baffin and Labrador currents. This would have allowed longer ice-free summers from eastern Baffin Island to southeastern Newfoundland and diminished chilling of the Gulf of St. Lawrence and the Gulf Stream. Furthermore, as pointed out by Williams ef al. (1995), the outflow of warm bottom water of Atlantic origin through the archipelago was then larger than now, allowing it to more strongly affect the then-deeper Baffin Shelf and fiords.

The mollusc record of the archipelago at $8 \mathrm{ka} \mathrm{BP}$ was similar to that at $9 \mathrm{ka}$. Both restricted and diverse arctic assemblages were widespread, the latter perhaps more than before. Mytilus edulis extended along the mainland coast to Bathurst Inlet, defining a shailow coastal zone of enhanced solar warming as today. The record of Mya arenaria from northeast Victoria island is dubious as is perhaps that of Macoma balthica farther south.

Just formed and expanding, Hudson Bay (Tyrrell Sea) was probably fully arctic due to a large meltwater and ice berg flux. An occurrence of Mytilus edulis along with Hiatella arctica dating $8.04 \mathrm{ka} \mathrm{BP}$ (UQ-761) from the northeastern part of the bay is plotted inside the ice margin (Fig. 26). Data from the Ottawa Islands suggest that the Mytilus site was not deglaciated so early (Andrews and Falconer, 1969), and attempts to replicate the date from that site have failed (cf GSC4332).

\section{MOLLUSCAN ZONES AT $7 \mathrm{ka} \mathrm{BP}$}

The most prominent change in molluscan zones between 8 and $7 \mathrm{ka} \mathrm{BP} \mathrm{(Fig.} \mathrm{27)} \mathrm{was} \mathrm{a} \mathrm{northward} \mathrm{expansion} \mathrm{of} \mathrm{the}$ temperate mollusc zone. The earliest records of the oyster Crassostrea virginica in the Gulf of St. Lawrence date just before $7 \mathrm{ka} \mathrm{BP}$. Its apparent absence earlier may be due to the near intractability of the submerged molluscan record; the earlier occurrence of Spisula solidissima at St. Anthony (8.17 ka) may better indicate expansion of warm-temperate fauna into the gulf. Nevertheless, by $7 \mathrm{ka} \mathrm{BP}$ at least the southwestern part of the gulf hosted warm-temperate fauna, likely in broad shallow waters that heated to $>20^{\circ} \mathrm{C}$.

Expansion of the temperate zone into the gulf, although still meagrely recorded, is a pivotal event in explaining modern molluscan distributions (Bousfield and Thomas, 1975). Warm-water taxa comprise $35 \%$ of marine invertebrate species in the southwestern Gulf of St. Lawrence. They probably settled the area during the regional marine thermal optimum but are now separated from the main range to the south by a cold-water gap of $1300 \mathrm{~km}$. Bousfield and Thomas (1975), without reference to the mollusc fossil record, placed the maximum range extension of warm-temperate fauna in the gulf at about $7 \mathrm{ka} \mathrm{BP}$ based on the hypsithermal pollen record. Current data do not refute this, but that date should be considered a minimum. They attributed the subsequent breach of the temperate zone to growing tidal amplitude in the Gult of Maine - Bay of Fundy, brought on by submergence. 
The more vigorous tides destroyed summer thermal stratification of nearshore waters and eliminated the warm-water faunas. The Gult of Maine was then re-invaded by its present boreal tauna.

The mollusc assemblages in Hudson Bay at $7 \mathrm{ka}$ BP resembled those of the High Arctic, dominated by Hiatella arctica as Wagner (1969) proposed. Throughout the interval $8.7 \mathrm{ka}$ BP Hudson Bay would have been strongly affected by meltwater and ice berg production, particularly from ice over Foxe Basin. A sparse record of boreal-subarctic species along the east coast and in western Hudson Strait indicates an incipient low arctic zone there. The low arctic faunal zone of the western Arctic possibly extended as a coastal strip as far as Boothia Peninsula. However, this relies on a single report of Mytilus edulis from there and on another from Bathurst Intet (Fig. 27). Two additional reports of the full-boreal Mya arenaria are dubious.

\section{MOLLUSCAN ZONES AT 6 ka BP}

Faunal zones at $6 \mathrm{ka} \mathrm{BP}$ (Fig. 28) were not greatly ditterent from those earlier. The most important changes involved the following: probable disjunction of the temperate zone in the Gulf of St. Lawrence; a well-documented expansion and diversification of the boreal-subarctic molluscan component in Hudson Bay indicating evolution toward present low arctic conditions; and expansion of a low arctic zone along a segment of the East Greenland coast, indicating the maximum effect of the West Spitsbergen Current. In contrast, there is suggestion of a small range retraction of boreal-subarctic molluscs along the northeast Baffin Island coast. There is a change from 16 thermophiles north of present limits dated 8$7 \mathrm{ka} \mathrm{BP}$ to 7 for the interval 7-6 ka BP and the area of occurrence is more restricted. Evidence for persistence of a low arctic fauna along the arctic mainland is limited to a single sample of Mytilus edulis south of Chantrey Inlet. Summer sea ice conditions in the archipelago were at their postglacial worst 7-6 ka BP (Dyke et al, in review b) and possibly the low arctic zone shrank to runoff-dominated inlets where disjunct communities survived for a while.

\section{MOLLUSCAN ZONES AT 5 ka BP}

There is little evidence of shifting of zones from 6 to $5 \mathrm{ka}$ BP (Fig. 29). However, the boreal-subarctic fauna along the northeast Baffin Island coast may have re-extended its range to Nawy Board Inlet between 6 and $5 \mathrm{ka}$ BP. During this interval Chlamys islandica reached its northernmost recorded position at Cape Herschel on east-central Ellesmere Island. Although boreal elements are less numerously represented in the West Greenland record by $5 \mathrm{ka}$ BP, continued presence of Zirphaea crispata indicates local coastal niches warmer than present (Funder and Weidick, 1991). The low arctic zone of East Greenland had either shrunk to niche environments or disappeared by 5 ka BP.

The faunal record from Hudson Bay for this interval is puzzling. Mytilus edulis occurs in only 1 sample dating 6-5 ka BP compared to 15 samples dating 7-6 ka BP and is not replaced by other boreat-subarctic elements. Nothing in the history of the region reasonably explains this.

\section{MOLLUSCAN ZONES AT 4 ka BP AND LATER}

Only the Baffin Bay and high arctic regions have well distributed local faunas dated to the interval 5-4 ka BP (Fig. 30 ). Molluscan zones elsewhere are based on an assumption of conservative differences from present and previous conditions. By 4 ka BP the low arctic zone had disappeared from East Greenland and the boreal zone from West Greeniand. However, boreal-subarctic species still extended fully up the northeast Baffin coast until shortly after $4 \mathrm{ka} \mathrm{BP}$, though their record is less numerous for the interval 5-4 ka BP than before.

The faunal database is increasingly impoverished through time in the late Holocene for various reasons discussed earlier. This unfortunately limits our ability to examine the response of molluscs to the hemispheric climate changes documented for the Neoglacial period (3-0 ka BP). However, data for the interval $4-3 \mathrm{ka}$ BP show the start of a large shift in molluscan zones: relraction of the subarctic boundary in Baffin Bay (Fig. 31). By 3 ka BP the boundary had retreated to the middle Baffin coast. Mytilus edulis and Macoma balthica north of there date $3.6 \mathrm{ka}$ BP or older; $M$. edulis remained in the vicinity of that boundary until about $2.8 \mathrm{ka} B \mathrm{P}$ after which it has no record north of its present limit other than at its relict outpost at Pond Intet (Fig. 32).

Williams et al. (1995) invoked diminished outflow of warm bottom water of Atlantic origin from the Arctic Ocean due to rebound of the Queen Elizabeth Islands, combined with shallowing of the inner northeastern Baffin Shelf and fiords, to account for this retreat of moliuscs. This mechanism may have played an influential role but two others should also be considered. First, the fact that the molluscs retreated during the Neoglacial suggests that reduced solar heating may have been responsible. Second, the Neoglacial period in the high arctic islands was characterized by a sharp increase in arrival of driftwood. Dyke et al. (in review a) implicate a westward diversion of much of the Transpolar Drift to explain this. Because that water filtered through the islands to the Baffin Current, it may also have lowered its temperature.

\section{NORTHWEST ATLANTIC REFUGIUM AND ROLE OF THE LABRADOR CURRENT}

To what extent can the present fossil mollusc database address the issue in our opening quote from Franz and Merrill (1980): "Little is known of the fate of boreal species, and to a lesser extent arctic-boreal species in the northwest Atlantic during the last glacial maximum?" The question here is essentially which species survived in full glacial refugia along the shoreline on the outer continental shelf in the western Norh Atlantic south of the Laurentide Ice Sheet and which species settled North America from Europe via Iceland and Greenland during the postglacial marine thermal optimum? Any settling from Europe betore establishment of the West Greentand Current about 9.4-9.1 ka BP seem improbable. However, starting about 9 ka BP many of the subarctic molluscs of eastern Canada may have arrived from Europe via Svalbard, Iceland, and Greenland.

Dated species occupying the southern Labrador to Gulf of Maine region before $9.5 \mathrm{ka} \mathrm{BP}$ are listed in Table XA in order 
TABLE $X$

Species from southern Labrador to Guif of Maine listed in order of oldest radiocarbon date ( $\mathrm{ka} B P$ ). Those present betore $9.5 \mathrm{ka} B P$ likely extended northward from the full-glacial refugium. Westem North Atlantic endemic and temperate species that have younger limiting radiocarbon dates are listed at the and of section $A$

\begin{tabular}{l} 
A. Dated species \\
\hline Portlandia arctica $(16.98)$ \\
Nucula proxima $(16.29)$ \\
Mesodesma arctatum (14.85) \\
Nucula tenuis $(14.47)$ \\
Balanus hameri $\{14.42)$ \\
Hiatella arctica $(14.4)$ \\
Balanus crenatus (14.25) \\
Macoma calcarea (14.03) \\
Mya truncata (13.9) \\
Serripes groenlandicus (13.8)
\end{tabular}

Mya arenaria (13.7)

Mya pseudoarenaria (13.5)

Macoma balthica (13.39)

Nucula delphinodonta (13.34)

Placopecten magellanicus (13.2)

Neptunea despecta iornata (13.2)

Buccinum tenuis (13.2)

Clinocardium ciliatum (13.1)

Portlandia arctica siliqua (13.0)

Astarte crenata subaequilatera (12.8)

Nuculana pernula (12.79)

Mytilus edulis (12.6)

Natica clausa (12.6)

Chlamys islandica (12.45)

Trichotrophis borealis (12.32)

Buccinum plectrum (12.26)

Buccinum terranovae (12.2)

Hemithyris pssittacea (12.1)

Cyrtodaria siliqua (12.0)

Spisula sp. (12.0)

Panomya arctica (11.95)

Balanus balanoides (11.95)

Astarte monfagui (11.9)

Ensis directus (11.5)

Astarte undata (11.34)

Thyasira sp. (11.3)

Haminoea solitaria (11.1)

Buccinum totteni? (11.1)

Lunatia pallida (11.1)

Buccinum undatum (11.0)

Spisula polynyma (10.98)

Crassostrea virginica (10.85)

Echinorachnius sp. (10.85)

Boreotrophon truncalus (10.8)

Astarte crenata (10.7)

Buccinum hancocki (10.7)

Lepeta caeca (10.6)

Arctica islandica (10.59)

Musculus niger (10.51)

Portlandia intermedja (10.23)

Plicitusus kroyeri (10.1)

Astarte borealis (10.0)

Balanus balanus (9.97)

Astarte montagui striata (9.97)
TABLE X (continued)

\begin{tabular}{lr}
\hline A. Dated species & $\begin{array}{c}\text { Time interval (ka BP) } \\
>14>13>12>11>10>9.5\end{array}$ \\
\hline Zirphaea crispata (9.85) & $\mathrm{x}$ \\
Astarte elliptica $(9.62)$ & $\mathrm{x}$ \\
Cyclocardia borealis (9.62) & $\mathrm{x}$ \\
Macoma moesta $(9.62)$ & $\mathrm{x}$ \\
Nuculana minufa (9.62) & $\mathrm{x}$ \\
Nuculana tenuisulcata (9.62) & $\mathrm{x}$ \\
Yoldia thraciaeformis $(9.62)$ & $\mathrm{x}$ \\
Colus sp. (9.62) & $\mathrm{x}$ \\
\hline
\end{tabular}

Amphiatlantic species (A), but not western North Atlantic endemic (E) or temperate species ( $D$, appearing after $9.5 \mathrm{ka}$ could possibly have migrated from Europe via Iceland and Greenland. Earliest appearances in the radiocarbon record (ka BP) of taxa not listed above are: Polinices (= Lunatia) heros $(8.85, E)$, Mercenaria mercenaria $(8.62, T)$, Mesodesma deauratum $(8.28, E)$. Thracia septentrionalis $(8.28, E)$, Mysella planulata (8.28, T). Panopea norvegia $(7.69, A)$, Cerastoderma pinnulatum (5.8), Nucella lapillus $(4.69$, A). Pecten irradians $(4.6,7)$, Littorina obtusata $(4.33, A)$, Acmaea testudinalis (4.33, A), Gukensia demissa (3.8, T), Littorina saxatilis (3.25. A), Pyramidella fusca (2.54, A), Lacuna vincta (2.31, A), Modiolus modiolus $(1.79, A)$, and Littorina littorea $(0.65, A)$.

B. Fegionally undated species from localities known to be $>9.5 \mathrm{ka}$ old.

Axinopsida orbiculata, Cerastoderma pinnulatum, Cylichna alba, Epitonium greenlandicum, Lyonsia arenosa, Lyonsia hyalina, Margarites, Mysella planulata, Neptunea lyrala decemcostata. Polinices heros, Retusa obtusa, Serpula vermicularis, Spisula solidissima, Tachyrhynchus erosum. Yoldia limatula

of oldest radiocarbon age determination. We suggest that these species expanded northward from the full-glacial refugium south of Long Island and along the continental shelf to the northeast. In addition to the 61 species listed in Table XA, Bloom (1963) and Wagner (1970) report an additional 15 species that have no regional radiocarbon record but must be older than $9.5 \mathrm{ka}$ BP (Table XB). The dated list expands the known membership of the western North Atlantic refugium (Franz and Merrill, 1980) by about 25 species. Listed elements are about $4 \%$ arctic, $25 \%$ arctic-boreal, $20 \%$ boreal-subarctic, $33 \%$ boreal, $9 \%$ temperate, and $7 \%$ widespread. In Franz and Merrill's (1980) listings of "numerically and ecologically prominent" molluscs, their appearance in the regional fossil record of the southeastern glaciated region before (after) $9.5 \mathrm{ka} \mathrm{BP}$ are: arctic-boreal gastropods, $19 \%(7 \%)$; arctic-boreal pelecypods $53 \%(6 \%)$; boreal gastropods, $14 \%$ (18\%); boreal pelecypods, $45 \%(3 \%)$; transhatteran gastropods, $0 \%(0 \%)$; and transhatteran bivalves, $14 \%(3 \%)$.

From the above we postulate that the Labrador Current may operate both as a biogeographic barrier and as a valve on glacial-interglacial time scales. It seems probable from the chronostratigraphic records that two groups of borealsubarctic molluscs migrate into eastern Canada during interglaciations - one into the high subarctic of Baffin Bay and Hudson Bay from Europe, the other into the Atlantic Provinces region from the glacial refugium to the south. Each 
glaciation forces a southward displacement of "European" molluscs to the full-glacial refugium in the western North Atlantic. Thus, just as the Atlantic received a flood of Pacific taxa during the transarctic migrations of the Late Tertiary, white the Pacific taxa diversified little and remained largely endemic, the western North Atlantic received migrants from the eastern North Atlantic, thus keeping degree of endemism on the American side low (Franz and Merrill, 1980). The central arctic islands during interglaciations that resemble the present one present a barrier to transarctic migrations of borealsubarctic species, at least via the western half of the Arctic Ocean.

\section{PROGRESSIVE EXTINCTION OF MYA PSEUDOARENARIA}

Mya pseudoarenaria Schlesch (Plate II) is the only mollusc in Canadian waters that appears to be approaching global extinction. It is reported in some radiocarbon samples as M. truncata forma ovata Jensen. Laursen (1966) supported Jensen's placement of it as "at most an infrasubspecies" but MacNeil (1965) and Lubinsky (1980) firmly considered it a separate species. Jensen (1900; see summary in English by Laursen, 1966) re-examined hundreds of collections reporting Mya arenaria from arctic regions and pointed out that they were all misidentifications of a form of Mya truncata that lacks the abrupt truncation of the shell. Laursen (1966) re-examined postglacial fossils reported as $M$. arenaria from Hudson Bay and Baffin Istand and determined that they too are $M$. truncata forma ovata. He also pointed out that some shells identified as $M$. arenaria from the postglacial of Maine are actually $M$. truncata forma ovata. This suggests the need to re-evaluate dated samples of $M$. arenaria from the Gulf of St. Lawrence. Likewise, Lubinsky (1980) determined that earlier collections of $M$. arenaria from Hudson Bay were Holocene fossils of $M$. pseudoarenaria. Dall (1924) reported Mya intermedia Dall (= M. pseudoarenaria Schlesch (Lubinsky, 1980)) in two postglacial fossil collections from Dolphin and Union Strait but no $M$. arenaria in any collection from the western Arctic. Samples identified as $M$. arenaria are still submitted for dating from arctic Canada and are treated here as probable $M$. pseudoarenaria.

Although widespread in early postglacial time, Lubinsky (1980) considered Mya pseudoarenaria to be nearly restricted to southeastern Hudson Bay and eastern James Bay. In James Bay it is dwarfed to about $25 \%$ of normal size due to depressed salinities. It also lives in outposts in Dolphin and Union Strait and off Point Barrow, Alaska (Dall, 1919; MacGinitie, 1959; MacNeil, 1965; map in Lubinsky, 1980, p. 91). More recent reports on Alaska suggest that it is more widespread that previously thought (Foster, 1991) but no indications are given of its abundance. Lubinsky (1980, p. 45) states: "There is no doubt that this species is close to extinction in its present relict area in the Canadian eastern Arctic. Schtesch (1931), MacNeil (1965), and Strauch (1972) showed that $M$. pseudoarenaria has retreated from the entire northwest Atlantic area." MacNeil identified it as present in the eastern North Atlantic (England) by Late Pliocene, apparently ahead of Mya truncata. It was among the earliest Pacific taxa to arrive at Iceland about $3 \mathrm{Ma}$ ago (Einarsson et al., 1967). It occurs in the second oldest aminozone reported by Mode (1985) on eastern Baffin Island, which is of early Pleistocene or Pliocene age (Miller, 1985; Feyling-Hanssen, 1985). Thus it has a long record of withstanding the stresses of Quaternary glaciations and interglaciations. It appears to have maintained a circumpolar distribution until the Late Pleistocene to early Holocene for it occurs in beds of that age in northern Russia, eastem Siberia, northern Alaska, West Greenland and Spitsbergen. Although of Pacific derivation, it may have been extinct there by Late Tertiary (MacNeil, 1965), though we suspect that it occupied the last glacial maximum refugium south of Beringia (see below), which may explain its present Alaskan distribution (Foster, 1991).

Our database has 50 dated postglacial records of $M$. pseudoarenaria and 11 dubious records of $M$. arenaria from arctic sites are probably its similar arctic relative (Plate II). $M$. pseudoarenaria fossils range in age from $13.5 \mathrm{ka}$ (GSC-4685) to about $3.5 \mathrm{ka} \mathrm{BP}$. The dubious $M$. arenaria occupy the same age range, except for one sample from southern Hudson Bay that dated $2.41 \mathrm{ka}$ BP (1-3907; Fig. 33). The remarkable features of its frequency distribution are its increasing representation until $3.5 \mathrm{ka} \mathrm{BP}$ and sudden decline. The decline may represent withdrawal of the animal into Hudson Bay. Laursen (1966) identified it in early (pre-radiocarbon dating) collections from Hudson and James bays. Further attention to its history in Hudson Bay (and elsewhere) could illuminate the processes involved in its apparent ongoing extinction.

Its early record, nine occurrences before $10.78 \mathrm{ka} \mathrm{BP}$, is entirely from the Gulf of St. Lawrence area. Only one dated occurrence is from the Champlain Sea, where Wagner (1970) also reported a single (different) occurrence. It apparently thrived in areas there with a subarctic marine environment and declined as boreal conditions spread. It was largely extinct in the gulf by $7 \mathrm{ka}$ but survived in places until $4 \mathrm{ka} B P$ (GSC-1403, Port au Choix, NF; UQ-862, Bic, QC; Beta-13854, Rivière-Madeleine, QC)

The animal appears to have spread into the western and central arctic by 10.07-9.64 ka BP (S-2683; GSC-4747). This implies that it either entered the region at the earliest possible(?) time from Baffin Bay, that it entered from the Pacific, or that it spread into the region along the Eurasian coast from the Barents Sea. Of these possibilities, entry from Baffin Bay seems improbable in that there is no record of it in there before $8.5 \mathrm{ka}$ BP. Entry from the Pacific seems most probable in that its appearance coincides with the arrival in the region of other animals from the Pacitic - the molluscs, Mytilus edulis and Macoma balthica, and the bowhead whale, Balaena mysticetus. MacNeil (1965) emphasized that he had found no record of the species in the present Bering Sea or elsewhere in the Pacific Ocean, though he does report it on the north coast of Alaska and in Dolphin and Union Strait based collections of the Canadian Arctic Expedition identified as Mya intermedia Dall by Dall (1919). Its present low arctic distribution suggests that it did not survive in the Arctic Ocean through the last glacial maximum; thus survival along the south coast of Beringia is suggested. Its apparent decline in the western Arctic at $7 \mathrm{ka} \mathrm{BP}$, with one outlier at about $5 \mathrm{ka} \mathrm{BP}$, coincides 


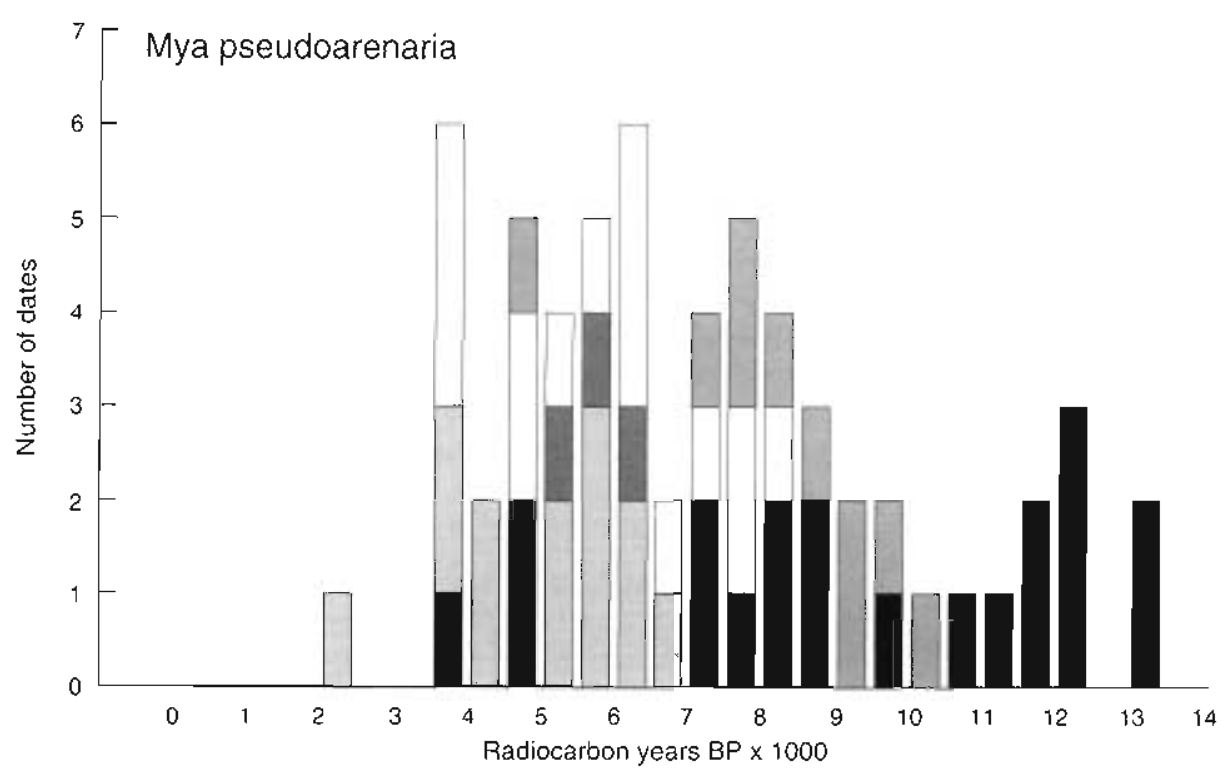

FIGURE 33. Radiocarbon dates on Mya pseudoarenaria $(n=50)$ and on Mya arenaria that are probably $M$. pseudoarenaria ( $n=11$ ).

Datations au radiocarbone de Mya pseudoarenaria $(n=50)$ et de Mya arenaria lesquels sont probablement Mya pseudoarenaria $(n=11)$.

Gulf of St Lawrence

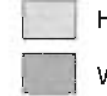

Hudson strait'bay

Foxe Basin Baffin Bay

Western \& central Arctic

with worsening sea-ice conditions there (Dyke et al, in review b). It may have shrunk to a small relict in Dolphin and Union Strait thereafter.

Mya pseudoarenaria was present along the Baftin Bay coast from 8.5-3.5 ka BP. This is the interval when subarctic conditions spread to the head of Baffin Bay on the Canadian side. Its retreat from there coincides with the retreat of boreal molluscs. It thus appears that in the Arctic Holocene record the species can be regarded as a thermophile. Presuming the reported Foxe Basin $M$. arenaria to be $M$. pseudoarenaria, it was present there 6.5-5 ka BP, essentially starting with regional deglaciation.

$M$. pseudoarenaria is not a prominent member of any regional fauna recorded here. Of all regions, it appears to have thrived best in the Gulf of St. Lawrence during its subarctic phase. In decline there by $10 \mathrm{ka} \mathrm{BP}$ as the subarctic zone shrank from most of the gulf, it may have been unsuccessful at penetrating arctic waters along the Labrador coast and unable to maintain its range area and continuity. Northward dispersion of its pelagic larvae up the Labrador coast at $10 \mathrm{ka}$ $\mathrm{BP}$ would have been prevented by the Labrador Current. Also, at $10 \mathrm{ka} \mathrm{BP}$ there may have been little Labrador coast available as staging sites. The Gulf of St. Lawrence population seems to have shrunk to extinction in the middle Holocene. Its apparent absence from the subarctic Labrador coast may be explained by such a history

The penetration of Mya pseudoarenaria into Baffin Bay and ultimately into Hudson Bay, therefore, probably occurred via Greenland. Although we have only two radiocarbon records of it from Greenland (K-1558,6.5 ka BP; I-5588; 6.03 ka BP), Laursen (1950) collected it from 16 raised marine sediment localities in West Greenland and the holotype specimen of the species is from Jensen's collection of "Pleistocene fossils" (presumably Holocene) from West Greenland (MacNeii,
1965, p. 37). According to Laursen's descriptions, it most commonly occurs in association with subarctic and boreal fossils. Feyling-Hanssen (1955) reported that "some of the numerous valves of Mya truncata from the Late-Pleistocene of Billefjorden were of forma ovata Jensen..."; otherwise its postglacial occurrence in Spitsbergen is undated. As yet there is no evidence that it ever established large regional populations in either Baffin Bay or along the western Arctic mainland; it seems to have been confjned to small, likely shifting niches.

With the Neoglacial retreat of the subarctic zone in the eastern Canadian Arctic and cooling of the subarctic zone in West Greenland, its range became restricted to Hudson Bay (Lubinsky, 1980). Why it failed to disperse southward along the Labrador coast is unclear. Its relict area apparently continues to shrink due to shoaling and lowering salinities in shatlow inshore zones as shown by ifs dwarfism in James Bay. The process of extinction of this animal, therefore, may be one of habitat elimination of a now relatively intolerant species. In the Pliocene and Early Pleistocene it may have exploited a wider range of habitats.

\section{SUMMARY AND DISCUSSION}

We have attempted a synthesis of the marine mollusc record of the last 18000 years for glaciated North America and Greenland. The database is rich and varied and representative of contemporaneous regional faunal assemblages. We have kept our view above the community level, where variations are governed by local controls of substrate type, water depth, and small scale salinity effects. Instead, we examined regional postglacial successions and gross shifts in molluscan zones in response to deglaciation and to oceanographic changes. Enough is known of molluscan zoogeography to place analysis at this level on a firm ecological basis. 

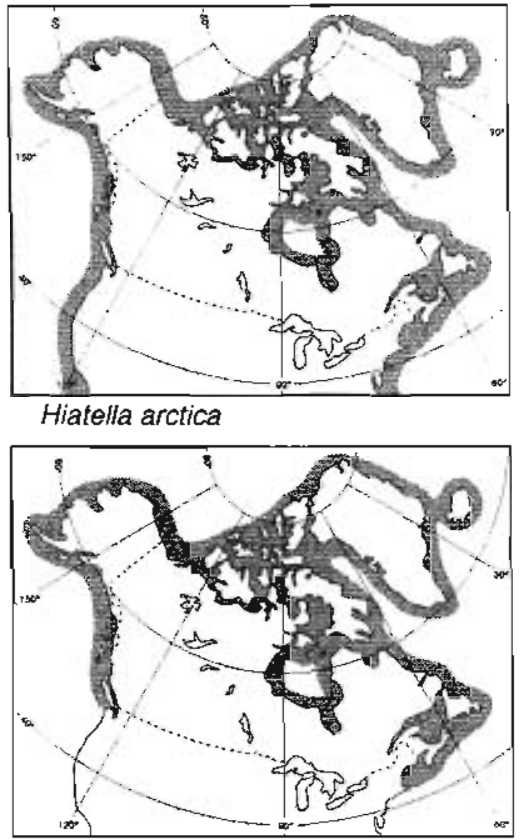

Macoma calcarea

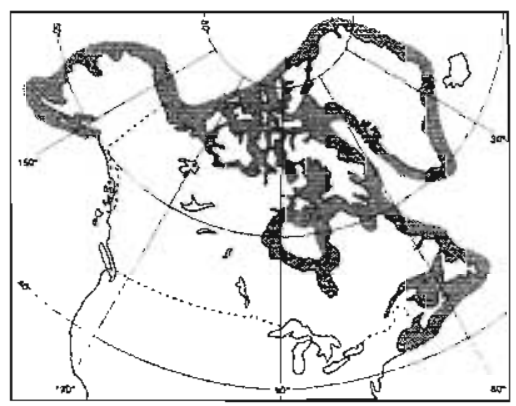

Astarte borealis

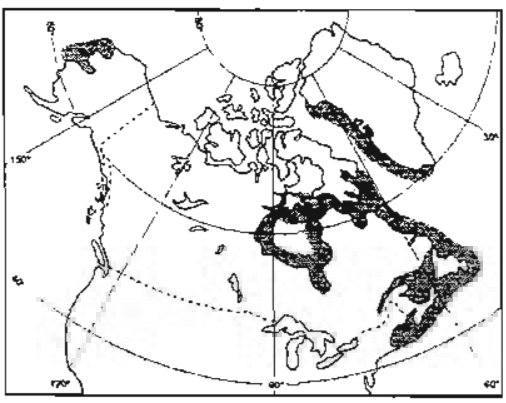

Chlamys islandica

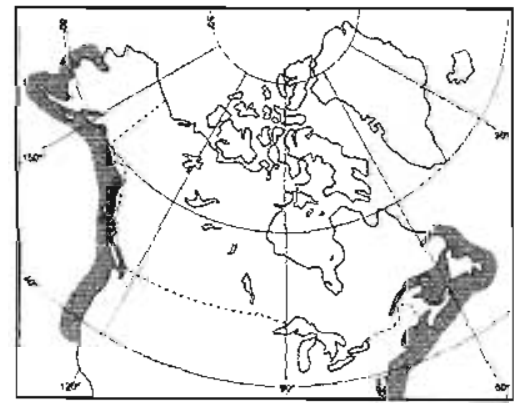

Mya arenaria
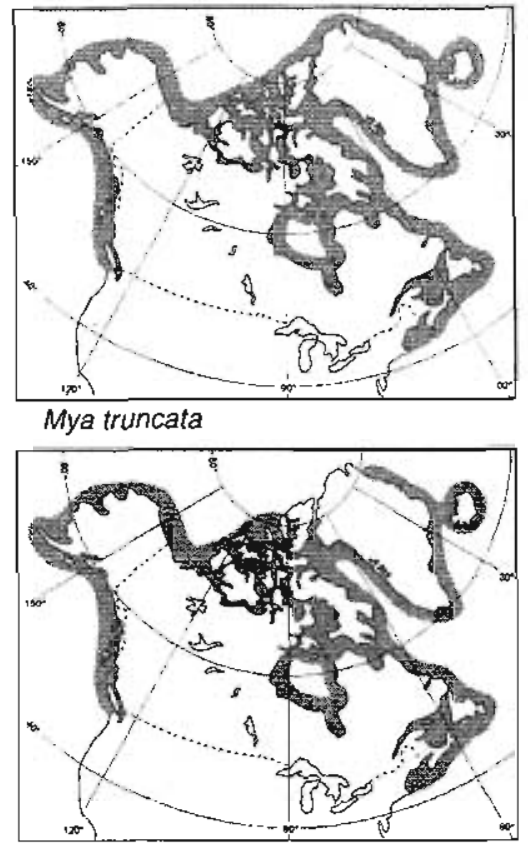

Clinocardium ciliatum

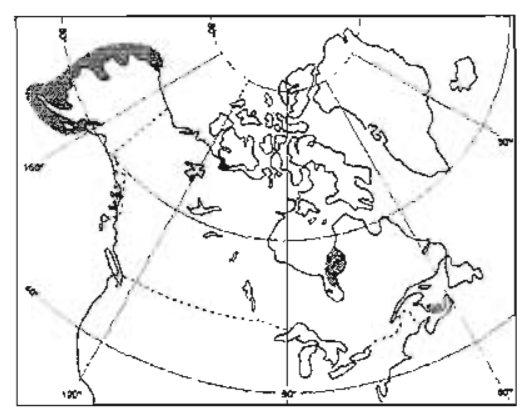

Mya pseudoarenaria

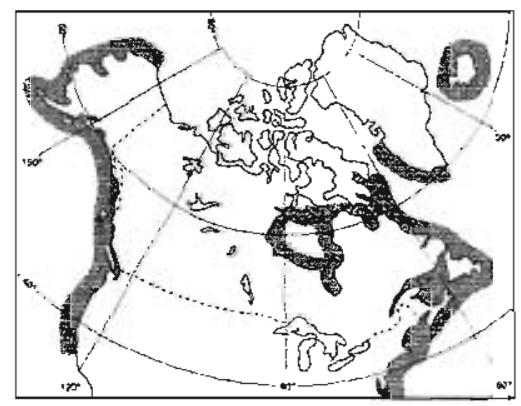

Macoma balthica

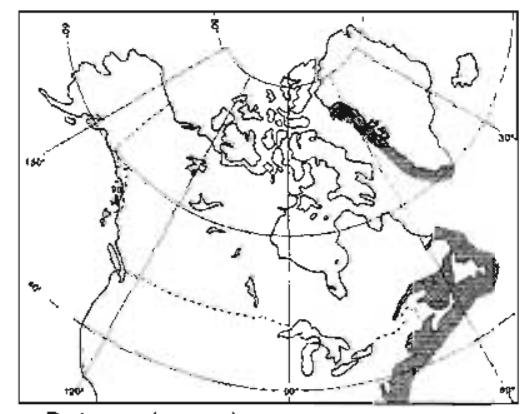

Balanus hameri

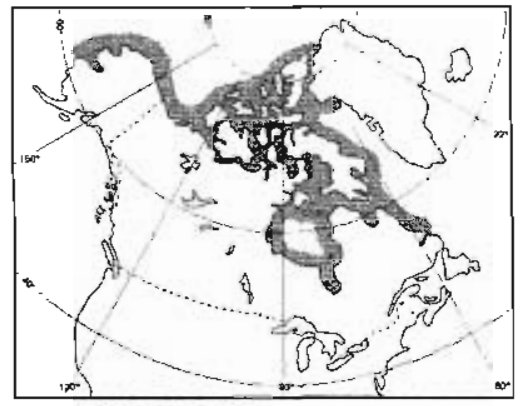

Portlandia arctica

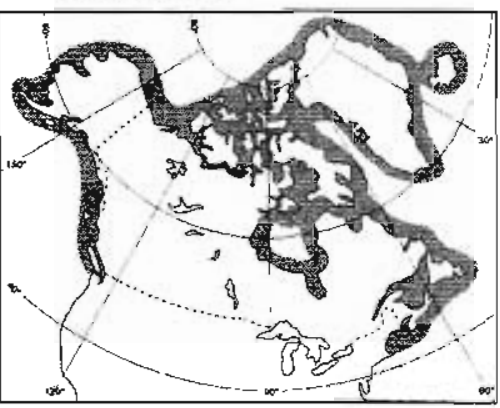

Serripes groenlandicus

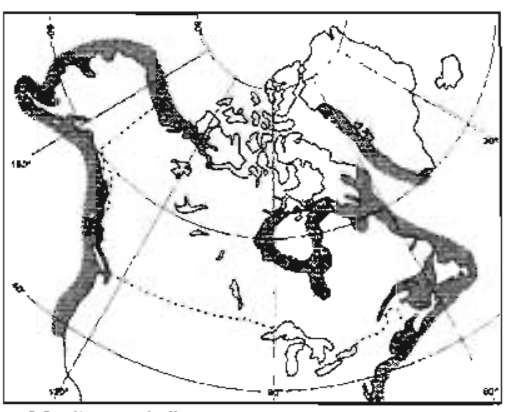

Mytilus edulls

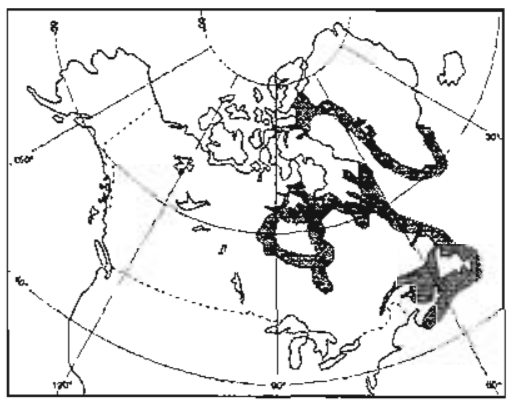

Astarte striata

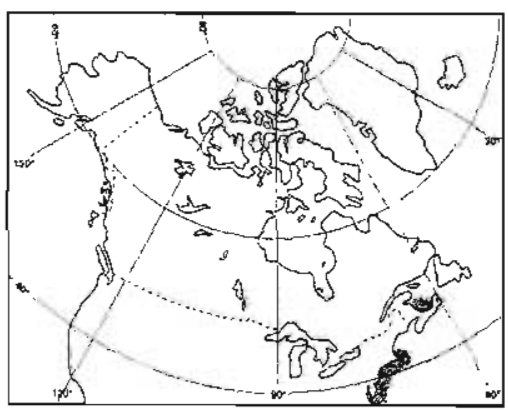

Crassostrea virginica

FIGURE 34. Distributions of the 15 marine invertebrates illustrated

Distribution des 15 invertébrés marins illustrés aux planches I et II. in Plates I and II. 
The counterparts of the present arctic, low arctic, subarctic, boreal, and temperate molluscan zones with their well-defined ranges of thermal conditions can be recognized in the fossil record and mapped with reasonable confidence (Fig. 34).

The database (3084 samples in 1993; 2465 classified) records 170 taxa but is dominated by arctic assemblages, with Hiatella arctica and Mya truncata singly or together accounting for $47.4 \%$ of classified records. Wholly arctic assemblages account for $70.1 \%$. Proceeding southward, the first boreal species added prominently to the record are Astarte striata, Mytilus edulis, Chlamys islandica, Macoma balthica, and Mya arenaria. The boreal assemblage comprises $16.1 \%$ of classified records. The oyster Crassostrea virginica represents the most thermophilous species. Only 15 species dominate the records.

There are strong suggestions of postglacial successions in many regional time series. In arctic regions that remained beyond the range of boreal taxa, the typical succession is Hiatella arctica followed by a Hiatella arctica - Mya truncata restricted assemblage, both of periglacial environments. This diversified through time by addition of Astarte borealis, Macoma calcarea, Serripes groenlandicus, and Clinocardium ciliatum, with order of appearance varying geographically in ill-defined ways. These regional successions remain inadequately defined and may be more complex and more informative than presently appears. The restricted assemblage has no modern analog but appears to be a valid paleontological entity even beyond present arctic regions. Extreme dominance of the early postglacial record in the high Arctic by $\mathrm{H}$. arctica may indicate that it was the most populous survivor in the Arctic Ocean at the last glacial maximum. As yet the only other firm candidate for survival in the Arctic Ocean is Portlandia arctica.

At 14 ka BP the combined arctic-subarctic molluscan zone was vast, extending from the Arctic Ocean to the Gulf of Maine. The boreal zone in the western Atlantic was highly compressed but was extensive in the eastern Pacific where the subarctic-arctic zone was compressed. These zones advanced northward as deglaciation progressed; the boreal zone occupied the Gulf of St. Lawrence by $12 \mathrm{ka} \mathrm{BP}$ and all of the Gulf of Alaska by $11 \mathrm{ka}$.

Moliuscs expanded greatly along the Arctic Ocean margin in the interval 12-11 ka BP from full-glacial polar refugia dominated by Hiatella arctica. Western arctic communities diversified about 10.5-10.3 ka BP when Bering Strait gave entry to other arctic species, including Mya truncata and probably Mya pseudoarenaria, as well as boreal-subarctic species from refugia in the north Pacific. Western arctic waters were warmer than present at that time. Meanwhile temperate species also advanced northward to the New England Shelf. Boreal species remained dominant in the Gulf of St. Lawrence 11-10 ka BP, but the Champlain Sea showed a reversion to faunas of more arctic aspect, possibly due to increased meltwater flow from proglacial lakes.

Important changes of molluscan zones between 10 and 9 ka BP reflect postglacial establishment of the West Greenland, Irminger, and Baffin currents or their migration to near- present positions. The North Atiantic Drift affected Svalbard by $9.4 \mathrm{ka}$ BP. The Baffin Current was not as chilling as today at 9 ka BP when boreal-subarctic molluscs exceeded present limits. Between 9 and $8 \mathrm{ka}$ BP boreal-subaretic molluscs extended to the head of Baffin Bay on both coasts and full-boreal conditions were established in part of southern West Greenland. The first thermophiles also occurred in East Greenland due to increased influence of the warm West Spitsbergen Current. At the same time the Labrador Current seems to have had a less chilling influence on the Gulf of St. Lawrence where temperate faunas appeared. A brief interval around $8.5 \mathrm{ka} \mathrm{BP}$ seems to have been one of more intensive change than for the rest of postglacial time. We postulate that much of this may have been in response to withdrawal of the western Laurentide lce Sheet margin from the Mackenzie watershed and its downstream effects on the oceanography and climatology of the North Atlantic. Concurrently, the distal part of the Transpolar Drift may have assumed a more westward flow and the North Atlantic Drift strengthened.

From 8-3 ka BP boreal molluscs exceeded present limits in the eastern Arctic. Virginian species also expanded into the Gulf of St. Lawrence 8-7 ka BP, if not earlier, but became separated from their main range shortly after as increasing tidal mixing in the Guff of Maine - Bay of Fundy region created summer-cold water conditions. Shortly after $3 \mathrm{ka} B P$ the subarctic moliuscan zone retreated $1000 \mathrm{~km}$ in western Baffin Bay to its present position. This probably reflects cooling of the Baftin and Labrador currents downstream to the Grand Banks.

Shifting of molluscan habitats and zones continues today. The greatest changes may be those due to relative sea level change. Hudson Bay and Foxe basin are shallowing at a rate of about $1 \mathrm{~m}$ per century while much of Atlantic Canada is submerging at about 0.3 m per century. In Hudson Bay, pressure on the relict oceanic fauna in its relatively small eastern trench will continue (Lubinsky, 1980), and in the Gulf of St. Lawrence, deepening waters will increase pressure on disjunct populations of temperate faunas. Bousfield and Thomas (1975) predicted that some of the latter, including commercially important species, will likely become extinct in Canadian waters.

Other future changes may result from sustained regional changes in precipitation and atmospheric circulation such as are predicted to accompany global warming. For example, it seems well established that historic changes in discharge of the Mackenzie River affected oceanic and atmospheric conditions broadly in the North Atlantic. And well-documented changes in North Atlantic circulation during the present century between Canada and Greenland led to shifts of complex marine ecosystems, involving many economically important species of fish (e.g. Atlantic cod, Gadus morhua; Atlantic salmon, Salmo salar) and marine mammals (e.g. pilot whale, Globicephala ventricosa; Dunbar, 1976; Harington, 1980).

The paleogeographic reconstructions are a fairly detailed record of how a complex molluscan ecosystem responded to vast, externally imposed environmental changes of the sort that create ecological bottlenecks and opportunities. The last glaciation did not result in extinction of any marine molluscan 
species other than Atractodon stonei, last known from the Sangamonian or Midole Wisconsinan (Clarke et al., 1972; Wagner, 1977). The marine record thus stands in stark contrast to the great depletion of terrestrial mammals at the close of the last glaciation (Martin and Klein, 1984). The lack of extinction of molluscs arising from the last glaciation may simply reflect the fact that only highly adaptive species had survived the many earlier Pleistocene glaciations. This is indicated by elimination in the North Atlantic of more than half of the transarctic migrants from the Pacific in the earlier Pleistocene (Franz and Merrill, 1980). The only mollusc apparently now threatened with global extinction, Mya pseudoarenaria, seems more affected by habitat elimination and migrational restrictions during and following deglaciation than by the extreme displacements of glaciation itself. But what was uniquely disadvantageous for this animal in the last deglaciation is entirely unclear.

Despite lack of extinctions, both the boreal zone in the western Alantic and the arctic zone in the noth Pacific were severely constricted to an extent that may have approached critical, especially for shallow water forms. On the other hand the arctic zone in the Atlantic was extended so vastly that arctic animals were long exposed to conditions of greater variety than they would have otherwise experienced.

\section{ACKNOWLEDGEMENTS}

Our gratitude goes to the ail those students of the Quaternary history of glaciated North America and Greenland who have contributed the 3083 radiocarbon dates used here. Because regional geological reports are little referenced in this paper, we acknowledge those who have been the major contributors of data, generally tens to hundreds of samples each. For Greenland: A. Weidick, S. Funder, C. Hjort, M. Kelly; for arctic Canada: B. Craig, J. Fyles, J. Andrews, W. Blake, jr., D. Hodgson, J. England, G. Miller, L. Dredge, J-S. Vincent, J. Gray; for eastern Canada: D. Grant, V. Prest, I. Brookes, H. Richard, J-M. Dubois, P. LaSalle, J. Veillette, N. Gadd; for NE USA: A. Bloom, M. Stuiver, H. Borns; for the Pacific: J. Clague, D. Easterbrook. A.S. Dyke's work in the Arctic has been supported by Polar Continental Shelf Project (GSC) and most of his shell samples have been dated by the Geological Survey of Canada Radiocarbon Dating Laboratory. R.N. McNeely's creation and maintenance of the Canadian Radiocarbon Database was stimulated by the need for a Canadian node in the International Radiocarbon Database. D.A. St-Onge and J-S. Vincent as directors of Terrain Sciences Division supported this effort as well as the paleogeographic interpretations of which this paper forms part. A. Aitken has identified species in numerous shell samples in the GSC collections. We are grateful to A. Moore of Terrain Sciences Division (GSC) Geographic Information Systems Laboratory for manipulation and display of data on the paleogeographic maps and to $T$. Barry for additional cartography. We thank A. Aitken (University of Saskatchewan), J.T. Andrews (University of Colorado), B.T. Alt (GSC Ottawa), J.G. Fyles (GSC Ottawa), J.B. Macpherson (Memorial University of Newfoundland), P. Mudie (GSC Atlantic, Dartmouth), and P.J.H. Richard (Université de Montréal) for helpful reviews of earlier drafts of the manuscript. Andrews and R. Gilbert (Queen's University) provided helpful formal reviews. The Climate System History and Dynamics Project is directed by W.R. Peltier (University of Toronto) and jointly funded by Environment Canada and the Natural Sciences and Engineering Research Council of Canada.

\section{REFERENCES}

Abbott, R.T., 1974. American seashells: The marine mollusca of the Allantic and Pacific coasis of Norlh America. Second edition, Van Nostrand Reinhold, Naw York, 6630 .

Aitken, A.E., 1990. Fossilization potential of arctic tjord and continental shelf benthic macrolaunas, p. 155-176. In J.A. Dowdeswell and J.D. Scourse. eds., Glaciomarine Environments: Processes and Sediments, Geologicał Society Special Publications 53,423 p.

Ailken, A.E. and Fournier, J., 1993. Macrobenthos communities of Cambridge, McBeth and Itirbilung fiords, Baffin Island, Northwest Territories, Canada. Arctic, $46: 60-71$.

Aitken, A.E, and Gilbert, R., 1986. The biota of intertidal flats at Pangnirtung Fiord, Baffin Island, Northwesi Territories. Le Naluratiste canadien, 113 $191-200$.

1989. Holocene nearshore environments and sea-level history in Pangrinung Fiord, Balfin Island. N.W.T., Canada. Arclic and Alpine Research, 21: $34-44$.

_ in press. Marine mollusca from Expedition Fiord, western Axel Heiberg Island, Northwest Territories, Canada. Arctic

Aksu, A.E. and Mudie. P.J., 1985. Late Quaternary stratigraphy and paleoecology of northwest Labrador Sea. Marine Micropaleontology, 9: 537 . 557.

Anderson. T.W., 1987. Terrestrial environments and age of the Champlain Sea based on pollen stratigraphy of the Otlawa Valley-Lake Ontario region. p. 31-42. in R.J. Fulton, ed., Quaternary geology of the Otiawa region. Ontario and Quebec. Geological Survey of Canada. Paper 86-23, 47 p.

Andrews, J.T., 1972. Recent and lossil growth rates of marine bivalves. Canadian Arctic, and Late-Quaternary arctic marine environments. Palaeogeography, Palaeoclimatology, and Palaeoecology, 11: 157-176.

1989. Quaternary geology of the northeastern Canadian Shield, p. 76 301. In R.J. Fultion, ed., Quatemary Geology of Canada and Greenland. Geological Survey of Canada, Geology of Canada, no. 1 (also Geological Society of America. The Geology of North America, $\mathrm{K}-1$ ), $839 \mathrm{p}$.

Andrews, J.T., Erienkeuser, H., Tedesco, K., Aksu. A.E. and Jull, A.J.T., 1994 Late Quaternary (slage 2 and 3 ) meltwater and Heinrich events, northwest Labrador Sea. Quaternary Research, 41: 26-34

Andrews, J.T., Evans, L.W., Willams, K.M., Briggs. W.M., Jull, A.J.T. Erienkeuser, H. and Hardy, I., 1990. Cryosphere/Ocean interactions at the margin of the Laurentide lce Sheel during the Younger Dryas chron: SE Baffin Shelf, Northwest Territories. Paleoceanography, 5: 921-935.

Andrews, J.T. and Falconer, G. 1969. Late glacial and postglacial history and emergence of the Oltawa Islands. Hudson Bay. NWT: Evidence on deglaciation of Hudson Bay. Canadian Journal of Earth Sciences, $6: 1263$. 1276.

Andrews, J.T., Dyke, A.S., Tedesco, K. and White, J.W. 1993. Meltwater along the arctic margin of the Laurentide Ice Sheet ( $8-12 \mathrm{ka}$ ): Stable isotopic evidence and implications for past salinity anomaties. Geology, 21: 881884

Andrews, J.T., Mode, W.N., Webber, P.J., Miller, G.H. and Jacobs, J.D., 1980. Report on the distribution of dwart birches and present pollen rain. Baffin Island, N.W.T., Canada. Arctic, 33: 50-58.

Arctic System Science, 1990. Ocean-atmosphere-ice interactions. Joint Oceanographic Institute Report, Washington. DC, $132 \mathrm{p}$.

Ardley, E., 1912. Occurrence of Ostrea in the Preistocene deposits of the vicinity of Montroal. Ottawa Naturalist, 26: 67. 
Armstrong, J.E., 1956. Surficial geology of the Vancouver area. British Columbia. Geological Survey of Canada, Paper 55-40.

Barry, R.G., 1989. The present climate of the Arctic Ocean and possible pas and future states, p. 1-46. In Y. Herman, ed., The Arctic Seas: Climatology, Oceanography, Geology, and Biology. Van Nostrand Reinhold, Now York. $888 \mathrm{p}$.

Bayfield. H.W., 1837. Notes on the geology of the north coast of the St. Lawrence. Transactions of the Geological Society of London, Series 2, 5: 89103.

Bennike, O., 1987. Quaternary geology and biology of the Jorgen Brunland Fjord area, North Greenland. Meddelelser om Gronland, Geoscience, 18. $24 \mathrm{p}$.

Bennike, O. and Böcher, J., 1990. Forest-tundra neighbouring the north pole: Plant and insect remains from the Plio-Pleistocene Kap Kobenhavn Formation, North Greenland. Aretic, 43: 331-338.

Berger, A.L., 1978. The long-term variations of the caloric insolation resulting from the earth's orbital elements. Quaternary Research. 9: 139-167.

Berggren, W.A. and Hollister. C.D., 1977. Plate tectonics and paleocirculation - a commotion in the ocean. Tectonophysics, 38: 11-48.

Bernard, F.P., 1979. Bivalve molluses of the western Beaufort Sea. Contributions in Science 313, Natural History Museum of Los Angeles County. LoS Angeles, California, $80 \mathrm{p}$.

1983. Catalog of the living Bivalvia of the eastern Pacitic Ocean: Bering Strait to Cape Hom. Canadian Special Publication of Fisheries and Aquatic Sciences $61.102 p$

Bernard, F.R., McKinnell, S.M. and Jamieson, G.S., 1991. Distribution and zoogeography of the Bivalvia of the eastern Pacific Ocean. Canadian Special Publication of Fisheries and Aquatic Sciences $112.60 \mathrm{p}$.

Bertelsen, E. 1937. Contributions to the animal ecology of the ljords of Angmagssalik and Kangerdlugssuaq in east Greenfand. Meddelelser om Grontand, 108(3). 58 p.

Bigras, P. and Dubois, J.-M., 1987. Répentoire commenté des datations ${ }^{14} \mathrm{C}$ du nord de l'estuaire el du Golfe du Saint-Laurent, Québec el Labrador. Université de Sherbrooke, Département de géographie, Butletin de recher. che 94-95-96, $166 \mathrm{p}$.

Bloom, A.L., 1963. Late-Pleistocene changes of sea level and postǵlacial crustal rebound in coastal Maine. American Journal of Science, 261:862879 .

Bohrman, G. Henrich, A. and Thiede, J., 1990. Miocene to Qualernary paleoceanography in the northern North Allantic: Variability in carbonate and biogenic opal accumulation, p. 647-675. In U. Bleil and J. Thiede, eds. Geological History of the Polar Oceans: Arctic versus Antarctic. NATO Advanced Science Institutes, Series C. Mathematical and Physical Sciences, 308. $823 \mathrm{p}$.

Bousfield, E.L., 1960. Canadian Atiantic sea shells. National Museum of Canada, Queen's Printer, Ottawa, $72 \mathrm{p}$.

Bousfield, E.L. and Thomas, M.L.H., 1975. Postglacial changes in distribution of littoral marine isvertebrates in the Canadian Allantic region. Proceedings of the Nova Scotia Institute of Science, Supplement 3: 47-60.

Broecker, W.S., Kennett, J., Flower, B, Teller, J., Trumbore, S., Bonani, G. and Wolfit, W. 1989. Routing of meltwater from the Laurentide Ice Sheet during the Younger Dryas cold episode. Nature, 341: 318-321.

Brouwers, E.M., 1994. Lale Pliocene paleoecologic reconstructions based on ostracode assemblages from the Sagavanirktok and Gubik formations, Alaskan North Slope. Arctic. 47: 16-33.

Carter, L.D., 198t. A Pleislocene sand sea on the Alaskan Arctic Coastal Plain. Science. 211: $381-383$.

Clarke, A.H., 1974. Molluscs from Baffin Bay and the northern North Ailantic Ocean. Ottawa, National Museum of Natural Sciences, Publications in Biological Oceanography 7, $23 p$.

Clarke, A.H., Grant, D.F. and Macpherson, E., 1972. The relationship of Airactodon stonei (Pilsbry) (Mollusca. Buccinidae) to the Pleistocene stratigraphy and paleoecology of southwestem Nova Scotia. Canadian Joumal of Earth Sciences, 9: 1030-1038.

Clayton. L. and Moran, S.R., 1982. Chronology of Late Wisconsinan glaciation in middie North America. Quaternary Science Reviews, 1: 55-82.

Coachman, L.K. and Bames, C.A., 1961. The contribution of Bering Sea water to the Arctic Ocean. Arctic, 14: 147-161.

1963. The movement of the Atlantic Water in the Arctic Ocean. Arctic. 16: 9-16.

COHMAP Members. 1988. Climatic changes of the last 18,000 years: Observations and model simulations. Science, 241: 1043-1052.

Craig. B.G., 1960. Surficial geology of north-central District of Mackenzie, Northwest Territories. Geological Survey of Canada, Paper 60-18, $8 \mathrm{p}$.

1961. Surficial geology of northern District of Keewatin, Northwest Territories. Geological Survey of Canada. Paper 61-5, $8 \rho$.

-1963. Surficial geology of Boothia Peninsula and Somerset, King William, and Prince of Wales islands. District of Franklin. Geological Survey of Canada, Paper 63-44. $10 \mathrm{p}$.

Cremer, M., 1989. Texfure and microstructure of Neogene-Quaternary sediments, ODP sites 645 and 646. Baffin Bay and Labrador Sea, p. 7 20. In S.P. Srivastava, M. Arthur, B. Clement et al., eds., Proceedings of the Ocean Drilling Program. Scientific Results. 105, 1038 p.

Curtis, M.A., 1975. The marine benthos of the arctic and subarctic continental sheives. Polar Record, 17: 595-626.

Dale. J.E.. 1985. Recent intertidal molluscs from the east-central coast of Ellesmere Island, Northwest Territories. Geological Survey of Canada, Paper 85-1B, 319-324.

1992. The relatlonship between the physical environment and benthic faunal communities in Pangnirtung Fiord, Baffin Island, N.W.T. Ph.D. thesis, Queen's University, $425 \mathrm{p}$.

Dale. J.E., Aitken, A.E., Gilbert, R. and Risk, M.J., 1989. Macrofauna of Canadian Arctic fiords. Marine Geology, 85: 331-385.

Dall, W.H., 1919. Mollusks, Fiecent and Pleistocene, southern party 1913-16. Report of the Canadian Arctic Expedition, 1913-18. Volume VIII, Part A. Acland, King's Printer, Ottawa. $20 \mathrm{p}$.

1924. Report on the Pleistocene fossils coilected on the arctic coast. p. 30-35. In Report of the Canadian Arctic Expedition 1913-1918. Volume $X I$ : Geology and Geography, Part A. Acland, King's Printer, Ottawa.

Dawson, Sir W.J., 1893. The Canadian Ice Age. W.V. Dawson, Montréal. 301 p.

De Vernal, A and Hillaire-Marcel, C., 1987. Paleoenvironments along the eastern Laurentide lce Sheet margin and timing of the last ice maximum retreat. Géographie physique el Quatemaire, 41: 265-277.

De Vemal, A. and Mudie, P.J., 1989. Late Pliocene to Holocene palynostratigraphy at OOP Site 645. Baffin Bay, p. 387-399. in S.P. Srivastava, M. Arthur, B. Clement, et al.. ed., Proceedings of the Ocean Drilling Program, Scientific Results. 105, 1038 p.

Dowdeswell, J.A., Mastin, M.A., Andrews, J.T. and McCave, I.N., 1995. Iceberg production, debris ratting, and the extent and thickness of Heinrich layers ( $\mathrm{H}-\mathrm{H}, \mathrm{H}+2$ ) in North Allantic sediments. Geology, 23: 301-304.

Dunbar, M.J., 1946. Note on the delimitation of the arctic and subarctic zones. Canadian Field Naturalist. 61: 12-14.

1968. Ecological development in polar regions: A study in evolution. Prentice.Hall Englewood Cliffs, $119 \mathrm{p}$.

1976. Climatic change and northern development. Arctic, 29: 183-193.

Dunbar, M.J. and Grainger. E.H., 1952. Station list of the "Calanus" expedition, 1947-50. Journal of the Fisheries Research Board of Canada, 9: 6582.

Durham, J.W. and MacNeil, F.S., 1967. Cenozoic migrations of marine invertebrates through the Bering Strait region, p. 326-349. in D.M. Hopkins, ed., The Bering Land Bridge. Stanford University Press, $495 \rho$.

Dyke, A.S. and Dredge, L.A., 1989. Quaternary geology of the northwestern Canadian Shield. p. 189-214. In R.J. Fulton, ed., Quaternary Geology of 
Canada and Greenland. Geological Survey of Canada, Geology of Canada. no. 1 (also Geological Society of America, The Gealogy of North America. $\mathrm{K}-1\}, 839 \mathrm{p}$.

Dyke, A.S. and Morris, T.F., 1990. Postglacial history of the bowhead whale and of dritwood penetration; implications for paleoclimate, central Canadian Arctic. Geological Survey of Canada, Paper 99-24, $17 \mathrm{p}$.

Dyke, A.S., Morris, T.F., Green, D.E.C. and England, J.H., 1992. Quaternary geology of Prince of Wales Island, Arctic Canada. Geological Survey of Canada, Memoir 433. $142 \mathrm{p}$

Dyke, A.S. and Prest, V.K., 1987. Late Wisconsinan and Holocene history of the Laurentide Ice Sheet. Geographie physique ef Quaternaire, 41: 237263.

Dyke, A.S., England, J., Reimnitz, E. and Jette, H., in review a. Changes in driftwood delivery to the Canadian Arctic Islands: A Hypothesis of postglacial oscillations of the Transpolar Drift. Arctic.

Dyke. A.S. Hooper, J. and Savelle, J.M., in review b. A history of sea ice in the Canadian Arctic Archipeiago based on the postglacial remairs of the bowhead whale (Balaene mysticetus). Arctic

Einarsson, T., 1964. On the question of late Tertiary or Quaternary land connections across the North Atlantic and the dispersal of biota in that area. Journal of Ecology, 52: 617-625.

Einarsson, T., Hopkins, D.M. and Doell, R.R., 1967. The stratigraphy of Tjörnes, northern lceland and the history of the Bering Land Bridge, $\rho .312-325$. in D.M. Hopkins, ed., The Bering Land Bridge. Stanford University Press. $495 \mathrm{p}$.

Eiriksson, J., 1980. Tjomes, North lceland: A bibliographical review of the geological research history. Jökei, 30: 1-20

Ellis, D.V., 1955. Some observations on the shore fauna of Baffin Island. Arctic, 8: 224-236.

1957. Marine infaunai benthos in arclic North America. Ph.D. thesis, McGill University, $98 \mathrm{p}$

1960. Marine infaunal benthos in Arctic North America. Arctic Institute of North America, Technical Paper 5.53 0.

Ellis. D.V. and Wilce, R.T.. 1961. Arctic and subarctic examples of intertidal zonation. Arctic, 14: 224-235.

Elson, J.A., 1969a. Late Quaternary matine submergence of Quebec. Revue de géographie de Montréal, 23: 247-258.

- 1969b. Radiocarbon dates. Mya arenaria phase of the Champlain Sea. Canadian Journal of Earth Sciences, 6: 367-372.

Evans. D.J.A., 1990. The last glaciation and relative sea level history of northwest Ellesmere Island, Canadian High Arctic. Journal of Quatemary Science, 5: 67-82.

Faibanks. R.G., 1989. A 17.000-year glacio-eustatic sea level record: Influence of glacial melting rates on the Younger Dryas event and deep-ocean circulation. Nature, 342,637-642.

Fedyakov, V.V. and Naumov, A.D. 1989, Marine Bivalvia of the Arctic Ocean, p. 303-324. In Y. Herman, ed., The Arctic Seas, Climatology, Oceanography, Geology, and Biology. New York, Van Nostrand Reinhold. $888 \mathrm{p}$

Feyling-Hanssen. R.W., 1955. Stratigraphy of the marine Late-Pleistocene of Billetjorden, Vestspitsbergen. Norsk Polarinstitutt Skrifter, 107: 186 p

1985. Lale Cenozoic marine deposils of east Baffin Island and East Greenland: Microbiostratigraphy, correlation, and age, p. 354-393. In J.T. Andrews, ed., Quaternary Environments: Eastern Canadian Arclic. Basfin Bay and Western Greenland. Allen \& Unwin. Boston, $774 \mathrm{p}$

Feyling.Hanssen, R.W., Funder, S. and Petersen, K.S., 1983. The Lodin EW Formation; a Plio-Pleistocene accurrence in Greenland. Bulletin of the Geological Society of Denmark, 31: 81-106.

Feyting-Hanssen, R.W. and Olssen, 1., 1960. Five radiocarbon datings of posiglacial shorelines in central Spitsbergen. Norsk Geogratisk Tidsskritt. XVII(1-4): $122-131$.

Fisher, D.A., Koemer, R.M. and Reen. N., 1995. Holocene climatic records from Agassiz Ice Cap. Ellesmere Island, NWT. Canada. The Holocene, 5: $19-24$
Fisher, T. and Smith, D.G., 1995. The maximum extent of Lake Agassiz in Saskatchewan and its relationship to the nonthwestern (Clearwater) outlet. Quatemary Science Reviews, 13: 845-858.

Forman, S.L., 1990. Svalbard radiocarbon date list 1. Occasional Paper No. 47. Institute of Arclic and Alpine Research, University of Colorado, $48 \mathrm{p}$.

Foster, N.R., 1991. Intertidal bivalves: A guide to the common marine bivalves of Alaska. University of Alaska Press, $152 p$.

Franz. D.R. and Merril, A.S., 1980. The origins and determinants of distribution of molluscan faunal groups on the shallow continental shelf of the northwest Atlantic. Malacologia, 19: 227-248.

Funder, S., 1989. Quaternary geology of the ice-free areas and adjacen shelves of Greenland, p. 743-792. In R.J. Fulton, ed., Quaternary Geology of Canada and Greeniand. Geological Survey of Canada, Geology of Canada, no. 1 (also Geological Society of America, The Geology of North America, K-1), $839 \mathrm{p}$.

Funder, S. and Weidick, $A_{n,}$ 1991. Holocene boreal molluscs in Greenland palaeoceanographic implications. Palaeogeography, Palaeoclimatology. and Palaeoecology, 85: 123-135.

Fyles, J.G., 1963. Surficial geology of the Home Lake and Parksville mapareas, Vancouver Island. British Columbia. Geological Survey of Canada, Memoir $318,142 \mathrm{p}$.

Fyles, J.G., Marincovich, L., Jr., Matthews, J.V., Jr. and Barendregt. R., 1991. Unique moltuse find in the Beautort Formation (Plicoene) on Meighen Island, Arctic Canada. Geological Survey of Canada, Paper 91-18: 105-112.

Golikov, A.N., 1989. Arctic Ocean gastropod prosobranchs, p. 325-340. in $Y$. Herman, ed., The Arctic Seas, Climatology. Oceanography, Geology, and Biology. New York, Van Nostrand Reinhold, $888 \mathrm{p}$

Görlich, K., Weslawski, J.M. and Zajaczkowski, M., 1987. Suspension settling effect on the macrobenthos biomass distribution in the Hornsund Fiord Spitsbergen. Polar Research, 5; 175-192.

Gradstein, F.M. and Srivastava, S.P., 1980. Aspects of Cenozoic stratigraphy and paleoceanography of the Labrador Sea and Baffin Bay. Palaeogeography. Palaeoclimalology, Palaeoecology, 30: 261-295.

Grant, D.R., 1989. Quatemary geology of the Allantic Appalachian region of Canada, p. 393-440. In A.J. Fulton, ed., Quatemary Geology of Canada and Greenland. Geological Survey of Canada, Geology of Canada, no 1 (also Goological Society of America. The Geology of North America, K-1). $839 \mathrm{p}$.

Gray, J.T., Lauriol, B., Bruneau, D. and Ricard, J.. 1993. Postglacial emergence of Ungava Peninsula and its relationship to glacial history. Canadian Joumal of Earth Sciences, 30: 1676-1696.

Grieg, J.A., 1909. Brachiopods and molluses with a supplement to the echinoderns. Report of the Second Norwegian Arctic Expedition in the "Fram" 1898-1902. 3. $95 \mathrm{p}$

Guiliksan, B., Holte, B. and Jakola, K.-J.. 1985. The soft bottom launa in Van Mijentjord and Raudfjord, Svalbard, p. 199-211. In J.S. Gray and M.E Christiansen, eds., Marine Biology of Polar Regions and Effects of Stress on Marine Organisms. John Wiley.

Hall, C.A., 1964. Shallow-water marine climates and molluscan provinces. Ecology, 45: 226-234.

Harington, C.A., 1980. The impact of climate changes on people in Canada and the National Museum of Natural Sciences climate change project. Syllogeus, 26: 5-15.

Herman, Y., ed., 1989. The Arctic Seas: Climatology, Oceanography, Geology, and Biology. Van Nostrand Reinhold, New York, $888 \mathrm{p}$.

Hewitt, R.A. and Dale, J., 1984. Growth increments of modern Mya truncata L. from the Canadian Arctic, Greenland, and Scotland. Geological Survey of Canada, Paper 84-18: 179-186.

Hillaire-Marcel. C., 1980. Les faunes des mers post-glaciaires du Québec quelques considerations paléoécologıques. Géographie physique on Quatemaire, 34: 3.59.

Hjort, C. and Funder, S., 1974. The subfossil occurrence of Mytilus edulis L in central East Greenland. Boreas, 3: 23-33. 
Hodgson, D.A., Tayior, R.B. and Fyles, J.G., 1994. Late Quaternary sea level changes on Brock and Prince Patrick islands, westem Canadian Arctic Archipelago. Géographie physique et Quaternaire, 48: 69-84.

Kelly, M., 1973. Radiocarbon dated shell samples from Norder Stromfjord, West Greenland, with comments on models of glacio-isostatic uplift. Gronlands Geologiske Undersogelse, Rapport 59, $20 \mathrm{p}$.

Kerr, J.W., 1980. Structural framework of the Lancaster aulacogen. arctic Canada. Geological Survey of Canada, Bulletin 319, 24 p.

Koerner, R.M., 1989. Oueen Elizabeth Islands glaciers, p. 464-473, In R.J. Fulton, ed., Quaternary Geology of Canada and Greenland. Geological Survey of Canada, Geology of Canada, no. 1 (also Geological Society of America, The Geology of North America, K-1). $839 \mathrm{p}$.

Koemer, R.M. and Fisher, D.A., 1990. A record of Holocene summer climate from a Canadian high-arctic ice core. Nature, 343: 630-631.

Kristoffersen, $Y ., 1990$. On the tectonic evolution and paleoceanographic significance of the Fram Strail gateway, p. 3-76. In U. Bleil and J. Thiede, eds., Geological History of the Polar Oceans: Arctic versus Antarctic. NATO Acvanced Science Institutes, Series C. Mathematica: and Physical Scir ences, 308 .

Lammens, J.J., 1967. Growth and reproduction in a tidal flat population of Macoma balthica. Netherlands Journal of Sea Pesearch, 3: 315.382.

Laursen, D., 1950. The stratigraphy of the marine Quatemary deposits in West Greenland. Meddelelser om Gronland, 151(1), $142 \mathrm{p}$. 1966. The genus Mya in the arctic region. Malacologia, 3: 399-418.

Lawer. L.A., Muller, R.D., Srivaslava, S.P. and Roes!, W., 1990. The opening of the Arctic Ocean, p. 29-62. In U. Bleil and J. Thiede, eds., Goological History of the Polar Oceans: Arctic versus Antarctic. NATO Advanced Science Institutes, Series C: Mathematical and Physical Sciences, 308 , $823 \mathrm{p}$.

Lemmen, D.S., Aitken, A.E. and Gilbert, R., 1994a. Early Hotocene deglaciation of Expedition and Strand fiords. Canadian High Arctic. Canadian Journal of Earth Sciences, 31: 943.958 .

Lemmen, D., Duk-Rodkin, A. and Bednarski, J., 1994b. Late glacial drainage systems aiong the northwestern margin of the Laurentide Ice Sheet. Quaternary Science Reviews, 13: 805-828.

Lubinsky, I., 1980. Marine bivalve molluscs of the Canadian centrai and eastern Arctic: Faunal composition and zoogeography. Canadian Bulletin of Fisheries and Aquatic Sciences, 207, $111 \mathrm{p}$

Lyell, Sir C., 1841. Remarks on some fossils and Recent sheils, collected by Captain Bayfield, R.N., in Canada. Transaction of the Geological Sociery of London, Series 2, 6: 135-141.

MacGinitie. N., 1959. Marine mollusca of Point Barrow, Alaska, Proceedings of the United States National Museum, 109: 59-208.

MacNeil, F.S., 1965. Evolution and distribution of the genus Mya, and Tertiany migrations of mollusca. United States Geological Survey, Professional Paper 483-G, $51 \mathrm{p}$.

Macpherson, E., 1971, The marine molluscs of Arctic Canada. National Museums of Canada, Publications in Biological Oceanography 3: $149 \mathrm{p}$.

Macpherson, J.B., 1988. Comments on "Late Wisconsinan and Holocene history of the Laurentide Ice Sheet" by A.5. Dyke and V.K. Prest. Geographie physique et Quaternaire, 42, 101-102.

Madsen, H., 1936. Investigations on the shore fauna of East Greenland with a sunvey of shores of arctic regions. Meddelelser om Gronland, 100(8): 1 79 .

- 1940. A study of the litforal fauna of Northwest Greenland. Meddelelser on Gronland, 124(5): 1-24.

Marchitto, T. and Wei, K-Y., 1995. History of Laurentide meltwater flow to the Gulf of Mexico during the last deglaciation, as revealed by reworked calcareous nannofossils. Geology, 23: 779-782.

Martel, A. and Chia, F.-S., 1991. Drilting and dispersal of small bivalves and gastropods with direct development. Joumal of Experimental Marine Biology and Ecology. 150: 131-147.
Martin, P.S. and Klein, R.G., 1984. Quaternary Extinctions: A Prehistoric Revolution. The University of Arizona Press, Tucson, $892 \mathrm{p}$.

Matthews, B., 1967a. Late Ouatemary marine fossils from Frobisher Bay (Baffin Island. N.W.T., Canada). Palaeogeography, Palaeoclimatology, and Palaeoecology, 3: 243-263.

1967b. Late Quatemary land emergence in northem Ungava, Quabec. Arctic, 20: 176-202.

McCann, S.B., Date, J.E. and Hale, P., 1981. Subarctic intertidal Hats in areas of large tidal range, southern Baffin 1sland, eastern Canada. Geographie physique ot Quaternaire, 35: 185-204.

McNeely, R. in press. Geological Survey of Canada radiocarbon dates XXXII. Geological Survey of Canada, Paper.

McNeely. R. and Jorgensen, P.K., 1993. Geological Survey of Canada radiocarbon dates XXXI. Geological Survey of Canada, Paper 91-7, $85 \mathrm{p}$.

Miller, G.H., 1985. Aminostratigraphy of Baffin Island shell-bearing deposits, p. 394-427. In J.T. Andrews, ed., Quaternary Environments: Eastern Canadian Arctic. Baffin Bay and Western Greenland. Allen \& Unwin, Boston, $774 \mathrm{p}$.

Miller, G.H. and Kaufman, D.S., 1990. Rapid fluctuations of the Laurentide ice Sheet al the mouth of Hudson Strait: New evidence for ocean/ice-sheet interactions as a control on the Younger Dryas. Paleoceanography, 5: 907gis.

Mode, W.N., 1985. Pre-Holocene pollen and molluscan records from eastern Baffin Island, p. 502-519. In J.T. Andrews, ad., Quaternary Environments: Eastern Canadian Arctic, Baffin Bay and Western Greenland. Allen \& Unwin, Boston, $774 \mathrm{p}$.

Molt, R.J.. Grant, D.R., Stea, R. and Occhietti, S.. 1986. Late-glacial climatic oscillation in Atfantic Canada equivalent to the Alierod/Younger Dryas event. Nature. $323: 247-250$

Mudie, P.J., De Vernal, A and Head, M.J., 1990. Neogene to Recent palynostratigraphy of circum-arctic basins: Resuts of ODP leg 104, Norwegian Sea, leg 105, Baffin Bay, and DSDP site 611. Irminger Sea, p. 609646. In U. Bleil and J. Thiede, ods., Geological History of the Polar Oceans: Arctic versus Antarctic. NATO Advanced Science Institutes, Series C. Mathematical and Physical Sciences, 308, $823 \mathrm{p}$.

Mudie, P.J. and McCarthy, F.M.G., 1994. Late Quaternary pollen transport processes, western North Atlantic: Data from box models, cross-margin and N-S transects. Marine Geology, 118: 79-105.

Mysak. L.A, and Manak, D.K., 1989. Arctic sea-ice extent and anomalies, 1953. 1984. Almosphere-Ocean, 27: 376-405.

Mysak, L.A., Manak, D.K. and Marsden, R.F., 1990. Sea-ice anomalies observed in the Greentand and Labrador seas during 1901-1984 and their relation to an interdecadal arctic climate cycle. Climate Dynamics, 5: 111133.

Mysak, L.A. and Power, S.B.+ 1991. Greenland Sea ice and salinity anomalies and interdecadal climate variability. Climatological Bulletin, 25: 81-91.

- 1992. Searice anomalies in the western Arctic and Greenland-Iceland Sea and their relation to an interdecadal climate cycle. Climatological Bulletin, 26: 147-176.

Ockelmann, K., 1958. The zoology of East Greenland, marine lamellibranchiata. Meddelelse: om Gronland, 122(4); $256 \mathrm{p}$

Osterman, L.E. and Nelson. A.R. 1989. Latest Quaternary and Holocene paleoceanography of the westem Baffir Island continental shelf, Canada: Benthic foraminiferal evidence. Canadian Journal of Earth Sciences, 26 : $2236 \times 2248$

Palmquist. $P$., 1991. Differences in the fossilization potential of bivalve and gastropod species related to their tile sites and trophic resources. Lethaia. 24: $287-288$

Payette, S., 1993. The range limit of boreal tree species in Québec-Labrador: An ecological and palaeoecological interprelation. Review of Palaeobotany and Palynology, 79: 7-30.

Penny, D.N., 1993. Late Phiocene to Early Pleistocene ostracod stratigraphy and paleoclimate of the Lodin Elv and Kap Kobenhavn formations, East 
Greenland. Palaeogeography, Palaeoclimatology, and Palaeoecology, 101: 49-66.

Piper, D.J.W. Mudie, P.J., Fader, G.B., Josenhans, H.W. MacLean, B. and Vilks, G., 1991. Quatemary geology. p. 475-607. In M.J. Keen and G.L. Williams, eds., Geolagy of the Continental Margin of Eastern Canada. Geological Survey of Canada, Geology of Canada, no. 2 (also Geological Society of America, Geology of North America, 1-1), 855 p.

Powell, E.N. and Davis, D.J., 1990. When is "old" shell really old? Journal of Geology, 98: 823-844.

Rahman, A., 1995. Reworked nannofossils in the North Atlantic Ocean and subpolar basins: Implications for Heintich events and ocean circulation. Geology, 23: 487-490.

Rahman, A. and De Vernal, A., 1994. Surface oceanographic changes in the eastem Labrador Sea: Nannolossil record of the last 31,000 years. Marine Geology, 121: 247-263.

Repenning, C.A. and Brouwers, E.M., 1992. Late Pliocene-Early Pleislocene ecologic changes in the Arctic Ocean borderlands. United States Geological Survey. Bulletin 2036, 37 p.

Richard. P.J.H., Veillette. J., Larouche, A.C.. Hêtu. B., Gray, J.T. et Gangloff, $P$. in review. Chronologie de la déglaciation en Gaspésie: nouvelles données et implications. Géographie physique el Quaternaire.

Richards, H.G., 1962. Studies on the marine Pleistocene: Port I. The marine Pleistocene of the Americas and Europe, and Parl II. The marine Pleistocene mollusks of eastern North America. Transactions of the American Philosophical Society, Now Series, 52, part 3, $141 \mathrm{p}$.

Ritchie, J.C., 1989. History of the boreal forest in Canada, p. 508-512. In R.J. Fulton, sd.. Quaternary Geology of Canada and Greentand. Geological Survey of Canada, Geology of Canada, no. 1 (also Geological Society of America, The Geology of North America, $k-1), 839 \mathrm{p}$.

Ritchie, J.C., Cwynar, L.C. and Spear, R.W., 1983. Evidence from northwest Canada for an early Holocene Milankovitch thermal maximum. Nature, 305: 126-128

Robertson, S., 1987. Qualernary and recent marine lauma of westem Newloundiand. B.Sc. thesis, Depanment of Geology. University of Otrawa, 84 p.

Rodrigues, C.G., 1987. Late Pleistocene invertebrate macrolossils, microlossils and depositional environments of the western Champlain Sea, p. 16-23. in R.J. Fulton, ed, Quaternary geology of the Otlawa ragion. Geological Sunvy of Canada, Pager 86-23, $47 \mathrm{p}$.

Rodrigues, C.G., Ceman, J.A. and Vilks, G., 1993. Late Quaternary paleoceanography of deep water masses off Gaspé Peninsula, Gulf of St. Lawrence: Foraminiferal evidence. Ganadian Journal of Earth Sciences. 30: $1390-1403$.

Rodrigues, C.G. and Richard. S.H., 1983. Late glacial and postglacial macrofossils from the Ottawa-St. Lawrence Lowtands, Ontario and Quebec. Geological Survey of Canada, Paper 83-1A: 371-379.

_-_ 1985. Temporal distribution and significance of Late Pleistocene fossils in the western Champiain Sea basin, Ontario and Quebec. Geological Survey of Canada, Paper 85-1B: 401-411.

- 1986. An ecostratigraphic study of Late Pleistocene sediments of the western Champlain Sea basin, Ontario and Quebec. Geological Survey of Canada. Paper 85-22, $33 \mathrm{p}$.

Rodrigues, C.G. and Vilks. G., 1994. The impact of glacial lake runoff on the Goldthwait and Champlain seas: The relationship between glacial Lake Agassiz runoff and the Younger Dryas. Qualernary Science Reviews, 13: 923-944.

Fuddiman, W.F., 1987. Northern Oceans, p. 1374154. In W.F. Ruddiman and H.E. Wright, eds., North America and Adjacent Oceans During the Last Deglaciation. Geology of North America, K-3, Geological Sociely of America, Boulder. $501 \mathrm{p}$.

Salvigsen, $O$. and Ósterholm, H., 1982. Radiocarbon dated raised beaches and glacial history of the northern cosst of Spitsbergen, Svalbatd. Polar Research, 1: $97-115$.
Schlesch, H., 1931. Klein Mitteilungen VII, Beirrag zur Kenniniss der marinen Mallusken-Fauna Islands, 1, 2. Arch. Molluskenkunde. 4: 133-155 (quoted by Lubinsky, 1980).

Shackleton, N.J., Backman, J.. Zimmerman, H.B., Kent, D.V., Hall, M.A. Roberts, D.G., Schnitker, D., Baldaul, J.G., Despraires, A., Homrighausen, R., Huddlestun, P., Kęne, J.B., Kaltenback, A.J., Krumsiek, K.A.O., Morton, A.C. Murray. J.W. and Westberg-Smith, J. 1984. Oxygen isotope callbration of the onsel of ice ratting in DSDP Site 522A: History of glaciation in the North Atlantic region. Nalure, 307: 620-623.

Smith. M.F.I., 1981. Type specimens of molluses in the National Museum of Natural Sciences, Ottawa. National Museums of Canada, Publications in Zoology, 15, $36 \mathrm{p}$.

Strauch. F., 1972. Phylogenese, adaplation und migrationeiniger nordischer mariner molluskengenera, Abh. Senckenb. Nalurtorsch. Ges., 531, 210 p. (quoled by Lubinsky. 1980).

Syvitski, J.P.M., Harrow, G.E., Alkinson, R.G.A., Moore, P.G. and Andrews, J.T., 1989. Batfin Island fiord macrobenthos: Bottom communities and environmental significance. Arctic, 42: 232-247.

Teller, J.T., 1985. Glacial Lake Agassiz and its influence on the Great Lakes, p. 1-16. In P.F. Karrow and P.E. Calkin, eds., Qualernary Evolution of the Great Lakes. Geological Association of Canada, Special Paper 30. 258 p.

1987. Proglacial lakes and the southern margin of the Laurentide Ice Sheet, p. 39-69. in W.F. Ruddiman and H.E. Wrighl, Jr., eds., North America and Adpacent Oceans During the Last Deglaciation. Geological Society of America, The Geology of North America, K-3, $501 \mathrm{p}$.

1990. Volume and routing of late-glacial runoff from the southern Laurentide Ice Sheet. Quatemary Research, 34: 12-23.

Teller, J.T. and Clayton, L., eds., 1983. Glacial Lake Agassiz. Geological Association of Canada, Special Paper 26. $451 \rho$.

Thorson, G., 1933. Investigations on shallow water animal communities in the Frans Joseph Fjord (Eas1 Greenland) and adjacent waters. Meddelelser om Gronland, 100(2): 1-70.

-1934. Contributions to the animal ecology of Scoresby Sound Fjord complex (East Greenland). Meddelelser om Gronland, 100(3): 1-67.

1936. The laval development, growth and metabolism of Arctic marine bottom invertebrates etc. Meddelelser om Gronland, 100(6), $155 \mathrm{p}$.

Tushingham, A.M. and Peltier, W.R., 1991. Ice-3G: A new global model of late Pleislocene deglaciation based on geophysical predictions of postglacial relative sea level change. Journal of Geophysical Research, 96(83): 4497-5423.

Valentine. J.W. 1989. How good was the lossil record? Clues from the California Pleistocene. Paleobiology, 15: 83-94.

Verrill, A.E., 1922. Report of the Canadian Arctic Expedition 1913-18. Acland King's Printer, Ottawa, volumes $1-8$, variously paginated.

Vibe, C., 1939. Preliminary investigations on shallow water animal communities in the Upernavik and Thule districts (northwest Greenland). Meddelelser om Gronland, 124(2): 1.42 .

Vilks, G., Wagner, F.J.E, and Pelletier, B.R., 1979. The Holocene marine environment of the Beaulort Sheil. Geological Survey of Canada, Bulletin 303, $43 p$

Vincent. J.S., 1989. Quaternary geology of the southeastern Canadian Shield, o. 249-275. In R.J. Fulton, ed. Quatemary Geology or Canada and Greenland. Geological Survey of Canada, Geology of Canada. no.1 (also Geological Society of America, The Geology of North America, K-1), $839 \mathrm{p}$.

Wagner, F.J.E., 1959. Paleoecology of the marine Pleistocene faunas of southwestern British Columbia. Geological Suncy of Canada, Bulletin $52,67 \mathrm{p}$.

1969. Faunal study, Hudson Bay and Tyrrell Sea, p. 7-48. in P.J. Hood, ed., Earth Science Symposium on Hudson Bay. Geological Survey of Canada. Paper 68-53: 7-48.

1970. Faunas of the Pleistocene Champlain Sea. Geological Survey of Canada, Bulletin 181, $104 \mathrm{p}$.

1975. Mollusca of the Straits of Canso area. Geological Survey of Canada, Paper 75-23, 29 o. 
1977. Palaeoecology of Pieistocene mollusca. Nova Scotia. Canadian Joumal of Earth Sciences, 14: 1305-1323.

1984. Jllustrated catalogue of the Moliusca (Gastropoda and Bivalvia) in the Allantic Geoscience Centre index collection. Geological Survey of Canada, M40-43/1984E, $76 \mathrm{p}$.

Walcott, R., 1972. Past sea levels, eustasy and deformation of the earth. Quaternary Research, 2: 1-14.
Williams, K.W., 1990. Late Quaternary paleoceanography of the western Batfin Bay region: Evidence from fossil diatoms. Canadian Journal of Earth Sciences, $27 ; 1487-1494$

Williams, K.W., Short, S.K., Andrews, J.T., Jennings, A.E., Mode, W.N. and Sywitski, J.P.M., 1995. The eastern Canadian Arclic at 6 ka: A time of transition. Góographie physique et Quaternaire, 49: 13-27.

\section{APPENDIX \\ INDEX AND GEOGRAPHIC RANGES OF DATED MARINE INVERTEBRATE FAUNAS}

\section{PHYLUM MOLLUSCA}

\section{CLASS GASTROPODA}

Acmaea testudinalis Müller, arctic-boreal, Arctic Islands to Connecticut. Bering Sea

Boreotrophon clathratus Linné, boreal-subarctic, southern Arctic to Maine

Boreotrophon truncatus Strom, boreal-subarctic, southern Arctic to Georges Bank, north coast of Alaska

Buccinum (hancocki) glaciale Linne, arctic-subarctic south to Gulf of St Lawrence and Washington State

Buccinum physematum Dall, arctic, Arctic coast from Bernard Harbour to Pt Barrow, south to Bristol Bay

Buccinum plectrum Stimpson, arctic-subarctic, Arctic Ocean to Gulf of St. Lawrence and Puget Sound

Buccinum (terranovae) polare Gray, subarctic, Greenland to Newfoundland, Arctic Ocean to Alaska Peninsula

Buccinum (tenuis) scaliforme Möller, arctic-boreal south to Maine and Washington State

Buccinum totteni Stimpson, boreal-subarctic, Labrador to Gulf of St. Lawrence

Buccinum undatum Linné, boreal, Labrador to New Jersey

Colus halli Dall, boreal, Bering Sea to Calitornia

Colus pubescens Verrill, boreal, subarctic to South Carolina

Colus togatus Morch, arctic, northern Ellesmere south to?

Cryptonatica clausa Broderip and Sowerby, Arctic Ocean to North Carolina, $=$ Natica clausa Broderip and Sowerby

Epitonium sp., many species, temperate to tropical waters

Fusitron oregonensis Redfield, boreal, Bering Sea to California

Haminoea solitaria Say, Virginian, southwestern Gulf of St. Lawrence to Georgia

Lacuna vincta Montagu, arctic-boreal, Labrador to New Jersey; Alaska to Puget Sound

Lepeta caeca Müller, arctic-boreal, central and eastern Arctic south to Cape Cod; Alaska to Vancouver Island

Littorina littorea Linne, boreal, southern Labrador to New Jersey

Littorina obtusata Linné, boreal, Labrador to New Jersey; Alaska to Puget Sound

Littorina saxatilis Otivi, subarctic-boreal, Baffin Island to New Jersey

Lora nobilis Möller, boreal. Greenland to Gulf of Maine: Bering Sea (= Propebela nobilis Möller; = Oenopota furricula Montagu in Canadian Arctic)

Lunatia (Euspira) pallida Broderip and Sowerby, widespread, panarctic south to North Carolina and California

Moelleria sp. Jeffreys, three species in North America, all cold water; Arctic seas to New England; Alaska to Queen Charlotte Islands

Natica clausa Broderip and Sowerby, arctic-boreal, Arctic Ocean to North Carolina and Calitornia
Natica pallida Broderip and Sowerby = Lunatia pallida Broderip and Sowerby

Neptunea despecta tornata Gould, boreal, Gulf of Si. Lawrence to Cape Cod

Notacmea testudinalis Müller, (= Acmaea testudinalis testudinalis Müller), Arctic to New York

Nucella delphinodonta Mighels, boreal, southern Labrador to New Jersey

Nucella (Thais) lamellosa Gmelin, boreal, Bering Strait to California Nucella lapillus Linné, boreal, southern Labrador to New York

Oenopota sp., many species, dominantly an arctic and boreal genus

Plicifusus kroyeri Möller, circumpolar, Greenland, Bering Sea

Polinices heros Say, (= Lunatia heros), Virginian, Gulf of St. Lawrence to North Carolina

Polinices pallidus = ? Lunatia pallida Broderip and Sowerby

Puncturella noachina Linné, circumpolar, south to Cape Cod and Aleutian Islands

Pyramidella fusca C.B. Adams, Virginian, southwestern Gulf of St. Lawrence to Florida (= Sayella fusca C.B. Adams)

Solariella sp. Wood, tropical to arctic waters

Tachyrhynchus erosus Couthouy, boreal, Greenland to Massachusetts; Alaska to British Columbia

Thais lamellosa $=$ Nucella lamellosa Gemlin

Thais lapillus Linné = Nucella lapillus Linné

Trichotropis borealis Broderip and Sowerby. arctic-boreal south to Maine and British Columbia

Turbonilla interrupta Totten, Virginian, Gulf of St. Lawrence to West Indies

Turritella sp., temperate to tropical waters

Vermetus sp., reported only in sample SI-725, Ellesmere Island; there are no true Vermitus in the United States (Abbott, 1974), nor probably in Canada; probabily a member of family Vermetidae

\section{CLASS PELECYPODA}

Aequipecten irradians sablensis Lamarck = Argopecten irradians sablensis Clarke

Arctica islandica Linné. Newfoundland to Cape Hatteras, mainty boreal-Virginian range

Arctinula greenlandica Sowerby = Delectopecten greenlandicus Sowerby

Argopecten irradians sablensis Clarke, Sable Island to Florida, extinct subspecies

Astarte alaskensis Dall, Pacitic endemic, subarctic-boreal, Bering Sea to Washington

Astarte banksii Leach $=$ A. montagui Dillwyn

Astarte (Tridonta) borealis Schumacher, arctic-subarctic, boreat east coast, south to Massachusetis; Alaska

Astarte crenata Gray, arctic-subarctic, south to Massachusetts 
Astarte crenata subaequilatera Sowerby, subarctic, warmer waters than other forms of A. crenata, Labrador to Florida

Astarte elliptica Brown, low arctic to boreal Atlantic, south to Massachusetts

Astarte montagui Dillwyn (= A. banksii Leach), boreal with subarctic outposts, south to Massachusetts and Aleutian Islands

Astarte striata Leach, boreal-subarctic with high arctic outposts, south to Gulf of St. Lawrence

Astarte undata Gould, boreal, Labrador to Chesapeake Bay

Axinopsida orbiculata Sars, arctic-subarctic, south to Massachusetts

Bathyarca (Arca) glacialis Gray, arctic-subarctic, boreal in Atlantic, south to Gulf of St. Lawrence

Bathyarca raridentata Wood, Pacific endemic in southwestern Canadian Arctic Archipelago

Cardium ciliatum, reported in sample W-996 from Washington; (= Clinocardium ciliatum)

Cerastoderma pinnulatum Conrad, boreal, Labrador to North Carolina

Chirona evermanni

Chlamys sp.

Chlamys hastata hericia Gould

Chlamys hericius $=C$. hastata hericja Gould

Chlamys (Pecten) islandica Müller, boreal-subarctic, Cumberland Peninsula and Greenland to Massachusetts; Alaska to Washington

Chlarmys jordani Arnold, boreal, Queen Charlotte Islands to Washington

Chlamys rubida Hinds, boreal, Alaska to southern California

Clinocardium cifiatum Fabricius, arctic-subarctic with boreat outposts. south to Cape Cod and Puget Sound: rare in Arctic Archipelago, abundant in eastern Arctic

Clinocardium echinatum, reported in sample I-6430, SW Greenland

Clinocardium nuttallii Conrad, boreal Pacific. Bering Sea to southern California (see QU-450 for C. nuttallii, incorrectly identified at Sept|sle)

Compsomyax subdiaphana Carpenter, boreal northeast Pacific, Alaska to California

Crassostrea virginica Gmelin, Virginian species, southwestern Gulf of St. Lawrence to Gulf of Mexico

Crenella decussata Montagu, bareal, Hudson Strait to Cape Hatteras, Bering Sea to San Pedro, California

Cyclocardia (Venericardia) borealis Conrad, boreal, Hudson Strait to North Carolina

Cyclocardia ventricosa Gould, boreal, Alaska to Santa Barbara. California

Cyrtodaria kurriana Dunker, high arctic, south to Alaska and Labrador

Cyrtodaria siliqua Spengler, boreal, Labrador to Rhode Island

Delectopecten (Pecten) greenlandicus Sowerby, high arctic, south to Newfoundland in deep waters, = Arctinula greenlandica Sowerby

Ensis directus Conrad, boreal-subarctic, southern Labrador to South Carolina

Ensis ensis reported in 1-2475, US Shelf; probably $=E$ directus

Gastrana irus Hanley = Macoma inquinata Deshayes

Gukensia sp. = Volsella sp.?

Gukensia demissa Dillwyn, Virginian, Gulf of St. Lawrence to Florida

Hiatella arctica Linné, arctic-subarctic, Arctic Ocean to West Indies and Panama in Pacific (southern occurrences in deep water)

Hinnites multirugosus Gate, temperate Pacific, British Columbia to Baja California

Limatura (Lima) subauriculata Montagu, boreal, Greenfand to Puerto Rico, Alaska to Mexico

Limatula hyperborea = Yoldia hyperborea (Loven) Torell

Lyonsia hyalina Conrad, Virginian, southwestern Gulf of St. Lawrence to South Carolina
Macoma balthica Linne, boreal with subarctic outposts; Hudson Bay, north to Cumberland Sound, south to Massachusetts; Bering Sea to Califomia; tolerant of low salinity

Macoma brota Dall, subarctic-boreal, Arctic Ocean to Puget Sound

Macoma calcarea Gmelin, arctic-subarctic, south to New York; Bering Sea to Washington

Macoma incongrua $=M$. obliqua Sowerby

Macoma inconspicua Broderip and Sowerby, Pacific, boreal-low arctic, east to Bathurst Inlet, south to southern California

Macome inquinata (= Gastrana irus Haniey), boreal, Bering Sea to California

Macoma liparea Dall, boreal, Aleutian Islands to northern California

Macoma moesta Deshayes, high arctic south probably to Ungava Bay

Macoma nasuta Conrad, boreal-temperate, Alaska to Baja Calitornia

Macoma obliqua Sowerby, subarctic-boreal. Pt Barrow to Washington

Macoma torelli (Steenstrup) Jensen, high arctic

Megayoldia thraciaeformis Storer = Yoldia thraciaeformis Storer

Mercenaria mercenaria Linné, Virginian, southwestem Gulf of St Lawrence to Gulf of Mexico

Mesodesma arctatum Conrad, boreal, Greenland to Chesapeake Bay

Mesodesma (arctalum) deauralum Conrad, boreal-subarctic, Greenland to Chesapeake Bay

Modiolus modiolus Linné = Volsella modiolus, southernmost arctic to Florida and to California

Musculus discors Linné, arctic with boreal outposts south to Cape Cod and Puget Sound

Musculus discors (Modiolaria) laevigata Gray, arctic-boreal, south to Cape Cod

Musculus niger Gray, arctic-boreal, Ellesmere Island and Greenland to Cape Hatteras, Alaska to Puget Sound

Mya arenaria Linné, boreal, Hamilton inlet to Florida; Aleutian Islands to northern California; arctic occurrences referred to $M$. arenania probably $M$. pseudoarenaria

Mya psevdoarenaria Schlesch (= $M$. truncata forma ovata Jensen), low arctic-subarctic, now nearly restricted to eastern Hudson Bay

Mya truncata Linné, arctic-subarctic, south to Massachusetts, common in northern Gulf of St. Lawrence; Arctic Ocean to Washington State

Mya truncata uddevalensis Forbes, most arctic occurrences probably uddevalensis

Mysella planulata Stimpson, Virginian, southwestern Gulf of St. Lawrence to Texas

Mytilus californianus Conrad, temperate. Aleutian Islands to Mexico

Mytilus edulis Linné, boreat-subarctic, Padloping Island and Greenland to Cape Hatteras (northern outpost at Pond Inlet); Pacific north and east to Bathurst Inlet in the west

Nucula bellotii Adams, arctic, replaced by $N$. tenuis in subarctic and boreal zones; Alaska north of Aleutian Islands

Nucula defphinodonta Mighels and Adams, boreal-subarctic, Hudson Strait to New England; outpost at Pond Inlet

Nucula expansa Reeve $=N$. belloti Adams in cold waters; $N$. tenuis in Atlantic

Nucula proxima Say, Virginian, Nova Scotia to Texas

Nucula sulcata, reported in sample K-994 from SW Greenland

Nucula tenuis Montagu, subarctic-borea;, Labrador to North Carolina; N. tenuis in cold water probably N. befloti

Nuculana fossa Baird, subarctic-boreal, Alaska to Puget Sound

Nuculana minuta Fabricius, boreal-subarctic, rare in high arctic, south to Massachusetts and Chatham Sound, British Columbia

Nuculana (Leda) pemula Müler. arctic with boreal outposts south to Massachusetts and Queen Charlotte Islands 
Nuculana tenuisulcata Couthouy, arctic-boreal, Arctic Ocean south to Cape Cod

Ostrea lirida Carpenter, boreal-temperate, Alaska to Baja Calitornia Palliofum imbrifer Lovén, arctic-boreal, arctic seas to New Jersey Palliolum greenlandicum Sowerby, high arctic

Pandora glacialis Leach, high arctic clrcumpolar, south to subarctic

Panomya arctica Lamarck, boreal-subarctic, Aleutian Istands to $\mathrm{Pt}$ Barrow, Arctic seas to Chesapeake Bay

Panopea norvegica Spengler, boreal, Guff of St Lawrence to Cape Cod

Pecten (Patinopecten) caurinus Gould, temperate. Aleutian Islands to Pt Reys, California

Pecten irradians, Virginian, Nova Scotia to North Carolina, $=$ Argopecten irradians Lamarck

Placopecten magellanicus Gmelin, boreal, Labrador to North Carolina

Pododesmus macroschisma Deshayes, Alaska to California

Portlandia arctica Gray, arctic, south to Hamilton Inlet; deeper waters only in the subarctic

Portlandia arctica siliqua Reeve, shores of Batfin Bay and Foxe Basin to Labrador Shelf, northern Alaska; more southerly than $P$. arctica

Portlandia frigida $=$ Yoldiella frigida Torell

Portlandia Intermedia (= Yoldiella intermedia Sars), high arctic; relict in eastern trench of Hudson Bay

Pontlandia lenticula (= Yoldiella lenticula Möller, arctic-subarctic, south to Maine

Protothaca staminea Conrad boreai-temperate, Aleutian Islands to Baja Calitornia

Protothaca fenerrima Carpenter, temperate, Vancouver to Baja California

Saxidomus gigantea Deshayes, boreal, Aleutian Islands to California

Serripes sp., reported from Pacific; presumably $S$. groenlandicus

Serripes groenlandicus Bruguière, arctic-subarctic, south to Cape Cod; not abundant in archipelago; abundant in eastern Arctic

Solen sicarius Gould, temperate, British Columbia to Baja Calitornia

Spisula polynyma Stimpson, boreal-subarctic, Labrador to Rhode Island, Arctic seas to Puget Sound

Spisula solidissima Dillwyn, Virginian. Nova Scotia to South Carolina

Thracia septentrionalis deffreys, Greenland to Long Island; rare in Canadian Arctic
Thyasira gouldi Philippi, arctic-subarctic south probably to Massachusetts

Tresus capax Gould, boreal-temperate, Kodiak Island to Monteray, Califomia

Yoldia arctica Messewitsch $=P$. arctica Gray

Yoldia glacialis $=P$. a. siliqua Reeve

Yoldia (Limatula) hyperborea (Loven) Torrell, arctic-subarctic, south to Newtoundland

Yoldia thraciaeformis Storer, boreal, Greenland to Cape Hatteras, Alaska to Puget Sound

Yoldiella fraterna Verrill and Bush, arctic, abyssal deep waters south to Georgia

Yoldiella frigida Torell, high arctic circumpolar

Yoldiella lenticula Möller, arctic-subarctic, south to Maine

Zirphaea crispata Linne, boreal, southern Labrador to South Carolina

\section{PHYLUM ARTHROPODA}

\section{CLASS CIRRIPEDIA}

Balanus sp.

Balanus balanoides, subarctic-boreal. Baffin Island to New Jersey Balanus balanus Linne, widespread, Arctic Ocean to Long Island

Balanus crenatus Bruguière, widespread, Arctic to New Jersey; Alaska to Santa Barbara, California

Balanus evermanni

Balanus hamerl Ascanius, boreal-subarctic, West Greenland and Hamilton Intet to North Carolina

\section{PHYLUM BRACHIOPODA}

Hemithyris psittacea Gmelin, arctic-boreal, Arctic Ocean to Gulf of St. Lawrence

\section{PHYLUM ECHINODERMATA}

\section{CLASS ASTEROIDEA}

Asterias vulgaris Verrill, southern Labrador to North Carolina

\section{CLASS ECHINOIDEA}

Echinorachinus sp., only species in Atlantic Canada is $E$. pama Lamarck, Arctic Ocean to Long Island

Strongylocentrotus dröbachiensis Müller, widespread, Arctic Ocean to New Jersey 